Channel and Dynamic Flow Characteristics of the Chattahoochee River, Buford Dam to Georgia Highway 141

GEOLOGICAL SLRVEY WATER-SUPPLY PAPER 2063

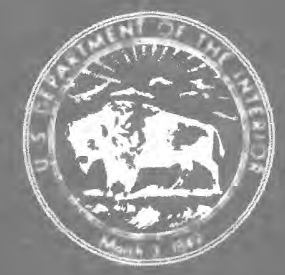


Channel and Dynamic Flow Characteristics of the Chattahoochee River, Buford Dam to Georgia Highway 141

By R. E. FAYE and R. N. CHERRY

GEOLOGICAL SURVEY WATER-SUPPLY PAPER 2063

River-quality assessment of the

Upper Chattahoochee River Basin, Georgia

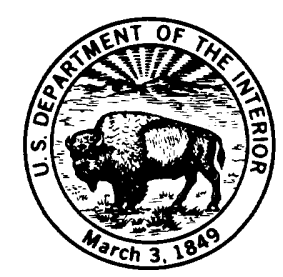




\section{UNITED STATES DEPARTMENT OF THE INTERIOR}

GECIL D. ANDRUS, Secretary

\section{GEOLOGICAL SURVEY}

H. William Menard Director

Library of Congress Cataloging in Publication Data

Faye, Robert E

Channel and dynamic flow characteristics of the Chattahoochee River-Buford Dam to Georgia Highway 141.

(Geological Survey water-supply paper; W-2063)

Bibliography: p.

Supt. of Docs. no.: I 19.13:2063

I. Chattahoochee River-Channel. 2. Stream measurements -Chattahoochee River. I. Cherry, Rodney N., 1928- joint author. II. Title. III. Series: United States. Geological Survey. Water-supply paper; W-2063.

TC425.C413F39 551.4'83'09758223 79-607024

For sale by Superintendent of Documents, U.S. Government Printing Office Washington, D.C. 20402 


\section{CONTENTS}

\begin{tabular}{|c|c|}
\hline \multicolumn{2}{|l|}{ Abstract } \\
\hline Introduction & \\
\hline Description of the reach & \\
\hline Data collection and reduction & \\
\hline Stage and discharge data & \\
\hline Cross-section data & \\
\hline Channel characteristics & \\
\hline Geometry & \\
\hline Roughness & \\
\hline Flow characteristics & \\
\hline Stage-discharge relations & \\
\hline Wave velocity & \\
\hline Velocity distributions & \\
\hline Method of computing highly dynamic flow at a gaged station & \\
\hline Model development & \\
\hline Numerical analysis & \\
\hline Computation scheme & \\
\hline Application & \\
\hline Digital program list (table 7) & \\
\hline Sensitivity analyses & \\
\hline Other comparisons & \\
\hline ( & \\
\hline s & \\
\hline Summary of data (tables 10-13) & \\
\hline
\end{tabular}

\section{ILLUSTRATIONS}

Figure 1. Map showing location of study reach and data-collection stations on the Chattahoochee River

Page

2.-6. Graphs showing measured stage of the Chattahoochee River during March 21-23, 1976, at:

2. Buford Dam -... 6

3. Georgia Highway 20 ...... 6

4. Littles Ferry Bridge _... 7

5. Georgia Highway $120 \ldots$

6. Georgia Highway $141 \ldots$ 
Figure 7.-10. Graphs showing measured discharge in the Chattahoochee River during March 21-23, 1976, at:

7. Georgia Highway 20

8. Littles Ferry Bridge

9. Georgia Highway 120

10. Georgia Highway 141

11. Diagrams showing selected channel cross sections_-- 10

12. Graph showing water-surface and thalweg profiles_-

13.-16. Graphs showing hysteretic stage-discharge relations on March 23, 1976, at:

13. Georgia Highway $20-0705$ to 1720 hours -.

14. Littles Ferry Bridge-0850 to 2110 hours --

15. Georgia Highway $120-1005$ to 2355 hours -

16. Georgia Highway $141-1105$ to 2310 hours -

17.-20. Graphs showing lateral velocity distribution during peak discharge on March 23, 1976, at:

17. Georgia Highway 20

18. Littles Ferry Bridge

19. Georgia Highway 120

20. Georgia Highway 141

21. Graph showing sensitivity of highly dynamic discharge to channel and flow parameters

22. Graph showing computed hysteretic stage-discharge relation on November 15,1956 , at Georgia Highway $20-0732$ to 1733 hours

\section{TABLES}

TABLE 1. Name and river-mile location of stage and discharge datacollection stations

Page

2. Summary of channel-roughness data

3. Maximum rates of change of stage and discharge on March 23, 1976

4. Maximum widths and areas of hysteretic stage-discharge relations on March 23, 1976

5. Summary of absolute wave-velocity data

6. Energy and momentum coefficients

7. Digital program list

8. Measured and computed discharges at Littles Ferry Bridge- 0850 to 2120 hours, March 23, 1976

9. Measured, computed, and rating-curve discharges at Georgia Highway 141-1105 to 2310 hours, March 23, 1976 
TABLE 10. Summary of river stage data 39

11. Summary of river discharge data _....... 54

12. Summary of tributary discharge data _............ 61

13. Summary of cross-section data

\section{UNITS OF MEASUREMENT/CONVERSION FACTORS}

Data listed in this report are defined in inch-pound units. A list of these units and the factors for their conversion to metric units is provided below.

Abbreviations of units are defined in the conversion table below or where they first appear in the text. Symbols are defined where they first appear in the text.

$\begin{array}{lll}\text { Multiply inch-pound unit } & b y & \text { to obtain metric unit } \\ \mathrm{ft} \mathrm{(foot)} & 3.048 \times 10^{-1} & \mathrm{~m} \text { (meter) } \\ \mathrm{ft} \text { (foot) } & 3.048 \times 10^{2} & \mathrm{~mm} \text { (millimeter) } \\ \mathrm{ft} / \mathrm{s} \text { (foot per second) } & 3.048 \times 10^{-1} & \mathrm{~m} / \mathrm{s} \text { (meter per second) } \\ \mathrm{ft} / \mathrm{s} \text { (cubic foot per second) } & 2.832 \times 10^{-2} & \mathrm{~m} / \mathrm{s} \text { (cubic meter per second) } \\ \mathrm{in.} \mathrm{(inch)} & 2.540 \times 10^{-2} & \mathrm{~m} \text { (meter) } \\ \mathrm{in.} \mathrm{(inch)} & 2.540 \times 10^{1} & \mathrm{~mm} \text { (millimeter) } \\ \mathrm{mi}^{3} \text { (mile) } & 1.609 & \mathrm{~km} \text { (kilometer) } \\ \mathrm{mi}^{2} \text { (square mile) } & 2.590 & \mathrm{~km}^{2} \text { (square kilometer) } \\ \text { tons (tons, short) } & 9.072 \times 10^{-1} & \mathrm{t} \text { (metric tons) } \\ \text { tons } / \mathrm{d} \text { (tons per day) } & 9.072 \times 10^{-1} & \mathrm{t} / \mathrm{d} \text { (metric tons per day) } \\ \text { tons/ft (tons per cubic foot) } & 3.204 \times 10^{1} & \mathrm{t} / \mathrm{m}^{3} \text { (metric tons per cubic meter) } \\ \text { tons/yr (tons per year) } & 9.072 \times 10^{-1} & \mathrm{t} / \mathrm{yr} \text { (metric tons per year) }\end{array}$

$$
{ }^{\circ} \mathrm{F}=9 / 5\left({ }^{\circ} \mathrm{C}\right)+32 \quad{ }^{\circ} \mathrm{C}=5 / 9 \quad\left({ }^{\circ} \mathrm{F}-32\right)
$$




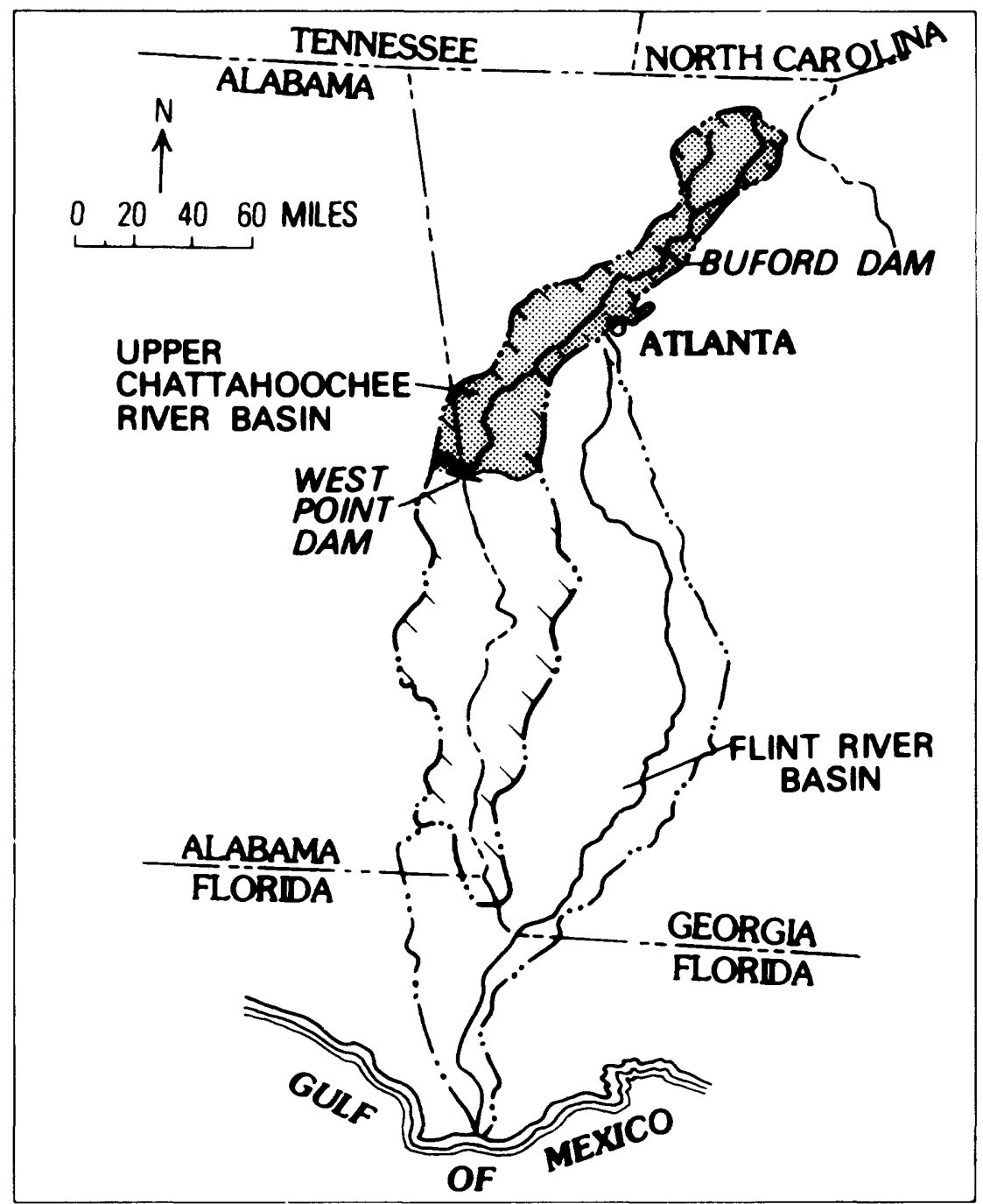

Map showing location of the Chattahoochee River. 


\title{
CHANNEL AND DYNAMIC FLOW CHARACTERISTICS OF THE CHATTAHOOCHEE RIVER, BUFORD DAM TO GEORGIA HIGHWAY 141
}

\author{
By R. E. FAYE and R. N. CHERRY
}

\section{ABSTRACT}

Detailed flow and cross-section data for a 17-mile reach of the Chattahoochee River in northeast Georgia are described and summarized. Flow data include measurements of highly dynamic stage and discharge at five stations during the period March 21-23, 1976. Flow data were collected at 5-minute intervals and are listed accordingly. Coordinate data for 39 cross sections in the study reach are also listed. A mathematical model is developed and applied whereby stage data collected at a single station can be used to compute highly dynamic discharge at the station. The model is based on the continuity and momentum equations that describe unsteady, one-dimensional flow in open channels. Both equations are transformed to a single quadratic equation which describes mean flow velocity at a single station. Flow-geometry parameters used by the model are computed using cross-section coordinates and the equation which describes the area of an irregular polygon. Use of the model in conjunction with highly dynamic stage data collected on March 23, 1976, provided close agreement between measured and computed discharges. The model was also used to investigate the sensitivity of highly dynamic discharge to channel and flow parameters. Computed discharge was most sensitive to changes in channel roughness and slope.

\section{INTRODUCTION}

This study is one part of the U.S. Geological Survey's Intensive River Quality Assessment of the Upper Chattahoochee River Basin (Cherry and others, 1976). The upper part of the basin (fig. 1, index map) encompasses an area of 3,550 square miles and includes the entire reach of the Chattahoochee River from its headwaters to West Point Dam, a distance of about 250 river miles. The reach of interest specific to this study is about 17 miles long and is bounded upstream and downstream by Buford Dam and Georgia Highway 141 respectively (fig. 1, table 1). River flow in this reach is influenced predominantly by regulation at Buford Dam and, to a lesser extent, by inflows from several tributaries (fig. 1). Flow regulation is mostly a function of the 
demand for hydroelectric power and the occurrence of downstream flooding.

Generation of hydroelectric power at Buford Dam is accompanied by the release of water downstream in the form of a pulse or wave. The flow characteristics of these waves are highly dynamic and are a direct function of the quantity of power produced and the length of the power production period. Downstream of Buford Dam, these waves significantly affect the flow and quality regimes of the Chattahoochee River. An evaluation of river flow and quality was a major objective of the River Quality Assessment and, as a first step, required the development of a transient, flow-routing model. In order to assess the flowrouting model's ability to simulate highly dynamic flows; it was first applied to the study reach (Buford Dam to Georgia Highway 141) in conjunction with a comprehensive, accurate, and detailed data base. The collection and interpretation of data for such a base were the general objectives of this study. Specific

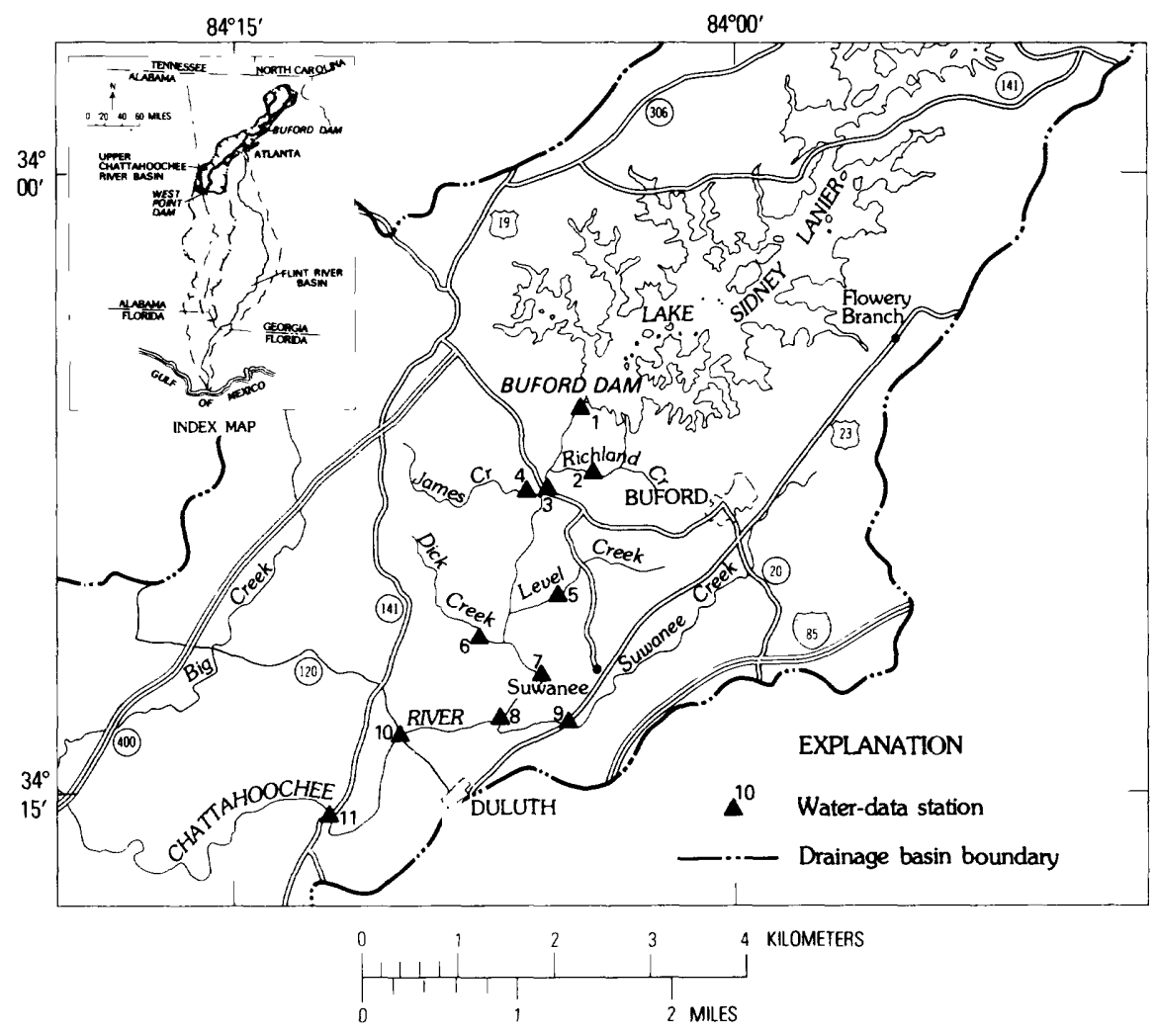

Figure 1.-Locations of study reach and data-collection stations. 
TABLE 1.-Name and river-mile location of stage and discharge data-collection stations

\begin{tabular}{|c|c|c|c|}
\hline $\begin{array}{c}\text { Map key } \\
\text { No. } \\
\text { (fig. 1) }\end{array}$ & Station or tributary name & $\begin{array}{l}\text { USGS } \\
\text { station } \\
\text { No. }\end{array}$ & $\begin{array}{l}\text { RM of station } \\
\text { or tributary } \\
\text { confluence }\end{array}$ \\
\hline 1 & Chattahoochee River at Buford Dam & 02334430 & 348.10 \\
\hline 2 & Richland Creek & 02334480 & 346.61 \\
\hline$\overline{3}$ & $\begin{array}{l}\text { Chattahoochee River near Buford } \\
\text { (Georgia Highway 20) }\end{array}$ & 02334500 & 345.80 \\
\hline 4 & James Creek & 02334520 & 345.48 \\
\hline $\mathbf{5}$ & Level Creek & 02334580 & 342.20 \\
\hline 6 & Dick Creek & 02334620 & 341.38 \\
\hline 7 & $\begin{array}{l}\text { Chattahoochee River at Littles } \\
\text { Ferry Bridge }\end{array}$ & 02334655 & 339.86 \\
\hline 8 & $\begin{array}{l}\text { Chattahoochee River at Gwinnett } \\
\text { County water intake }\end{array}$ & 02334695 & 338.19 \\
\hline $\mathbf{9}$ & Suwanee Creek & 02335000 & 338.14 \\
\hline 10 & $\begin{array}{l}\text { Chattahoochee River near Duluth } \\
\text { (Georgia Highway 120) }\end{array}$ & 02334950 & 335.26 \\
\hline 11 & $\begin{array}{l}\text { Chattahoochee River near Norcross } \\
\text { (Georgia Highway 141) }\end{array}$ & 02335000 & 330.77 \\
\hline
\end{tabular}

objectives included (1) a description of dynamic flow characteristics in the study reach, (2) a description of channel geometry and roughness, and (3) the presentation of a method to compute highly dynamic discharge at a gaging station using channel characteristics and stage data measured at the station. This computation method (objective 3 ) is presented in the form of a mathematical model but should not be confused with the flow-routing model mentioned previously. The development and application of the flow-routing model is described by Jobson and Keefer (1978).

On occasion in this text points on the Chattahoochee River will be designated by river mile ( $R M)$. Zero river mile ( $R M 000.00$ ) is defined as the confluence of the Flint and Chattahoochee Rivers near the Georgia-Florida border (fig. 1, index map).

The scope of this study included (1) the collection of detailed stage and discharge data at selected stations and (2) the collection of detailed cross-section data at approximately half-mile intervals throughout the study reach. All cross-section altitudes were based on the NGVD (National Geodetic Vertical Datum) of 1929. Stations where flow data were collected are listed in downstream order in table 1 and are keyed to the numbered locations shown on figure 1. The river mile listed for tributary streams (table 1) is the location of each stream's confluence with the Chattahoochee River.

\section{DESCRIPTION OF THE REACH}

Throughout the study reach, the channel of the Chattahoochee River is oriented to the southwest and is contained mostly within the zone of cataclasis of the Brevard Fault (Georgia Department 
of Natural Resources, 1976). Major tributaries along the reach include Richland Creek, James Creek, Level Creek, Dick Creek and Suwanee Creek (fig. 1, table 1). Channel cross sections are rectangular to trapezoidal in shape and are characterized by high, steep banks and sand beds. Shoals and rock beds do occur, however, and are most prominent downstream of Buford Dam, upstream of the confluence with Level Creek, and upstream of Georgia Highway 141. Commercial sand dredges are located on the river upstream of the confluence with James Creek, at Littles Ferry Bridge and just downstream of Georgia Highway 120. The Gwinnett County water-supply intake is located in the reach just upstream of the Suwanee Creek confluence. Stream bank erosion through the reach is severe and is caused, for the most part, by the rapidly changing flow conditions resulting from hydropower production at Buford Dam. The root systems of mature trees that lined formerly stable river banks have been undermined by erosion and thousands of large trees have fallen into the channel. These undermined trees are a prominent feature of the channel, especially at low flow, and probably affect channel roughness characteristics at higher flows.

U.S. Geological Survey gaging stations (fig. 1, table 1) are located just downstream of Buford Dam (1), at Georgia Highway 20 (3), and at Georgia Highway 141 (11).

\section{DATA COLLECTION AND REDUCTION STAGE AND DISCHARGE DATA}

Collection of stage and discharge data occurred intensively over a 3-day period beginning March 21, 1976. Initial flow conditions in the river were steady and low. Commencing early in the morning of March 22 regulated discharge at Buford Dam increased to approximately $4,000 \mathrm{ft}^{3} / \mathrm{s}$ (cubic feet per second) and was maintained at that rate for about 20 hours before returning to low flow. On March 23, regulated discharge at Buford Dam resembled a typical hydropower wave or pulse; peaking at about $8,000 \mathrm{ft}^{3} / \mathrm{s}$ just downstream of the dam. Stage measurements during the 3-day, data-collection period were made continuously, at 5-minute intervals, using automatic digital recorders at gaging stations just downstream of Buford Dam and at Georgia Highway 20. At Georgia Highway 141, stage was continuously measured by analog recorder and frequently by wire weight. Stage measurements were made at Littles Ferry Bridge and at Georgia Highway 120 by measuring the vertical distance between the water surface and an established reference point. Such measurements 
were made continuously at Littles Ferry Bridge at 10-minute intervals. Measurements at Georgia Highway 120 were made at 5 -minute intervals but only in conjunction with discharge measurements. The stage record collected at each station is listed in the summary of data (table 10) and shown graphically in figures 2 to 6.

Discharge measurements during the period March 21-23, 1976 were made at Georgia Highway 20, at Littles Ferry Bridge, at Georgia Highway 120, and at Georgia Highway 141. Continuous discharge measurements were obtained at each of these stations during the periods of rise and peak discharge on March 22 and during most of the period of unsteady discharge on March 23. In general, measurements of discharge followed procedures outlined by Buchanan and Somers (1969) for data collected during rapidly changing stage. Prior to the collection of discharge data, a minimum of seventeen (17) vertical positions were established across the river section at each station. During measurement, each position was occupied sequentially and the flow depth, mean velocity, and time were recorded. Because the distance between verticals was known, each measurement defined an instantaneous partial area and mean velocity. The product of these areas and velocities provided a series of partial discharges relative to each vertical over the total period of measurement. Plotting the partial discharge against time and connecting the points with a smooth curve provided a continuous record of instantaneous discharge at each vertical. The sum of each partial discharge at a given time was considered equivalent to the instantaneous river discharge at the station at that time. Instantaneous discharges were computed in this manner at each station and are listed, at 5-minute intervals, in the summary of data (table 11). The discharge data are presented graphically in figures 7 to 10 .

Measurements of instantaneous tributary discharge were made infrequently during the data-collection period. Stage measurements at tributary stations were made frequently, however, and were used in conjunction with established rating curves to estimate tributary flow. Tributary discharges during the period of interest are listed in the summary of data (table 12).

Withdrawals at the Gwinnett County Water intake averaged $16 \mathrm{ft}^{3} / \mathrm{s}$ during March 21-23, 1976.

\section{CROSS-SECTION DATA}

Cross-section data at a total of 30 locations were obtained by leveling cross country from a known bench mark to the cross- 
FigURE 2.-Measured stage of the Chattahoochee River at Buford Dam, March 21-23, 1976.

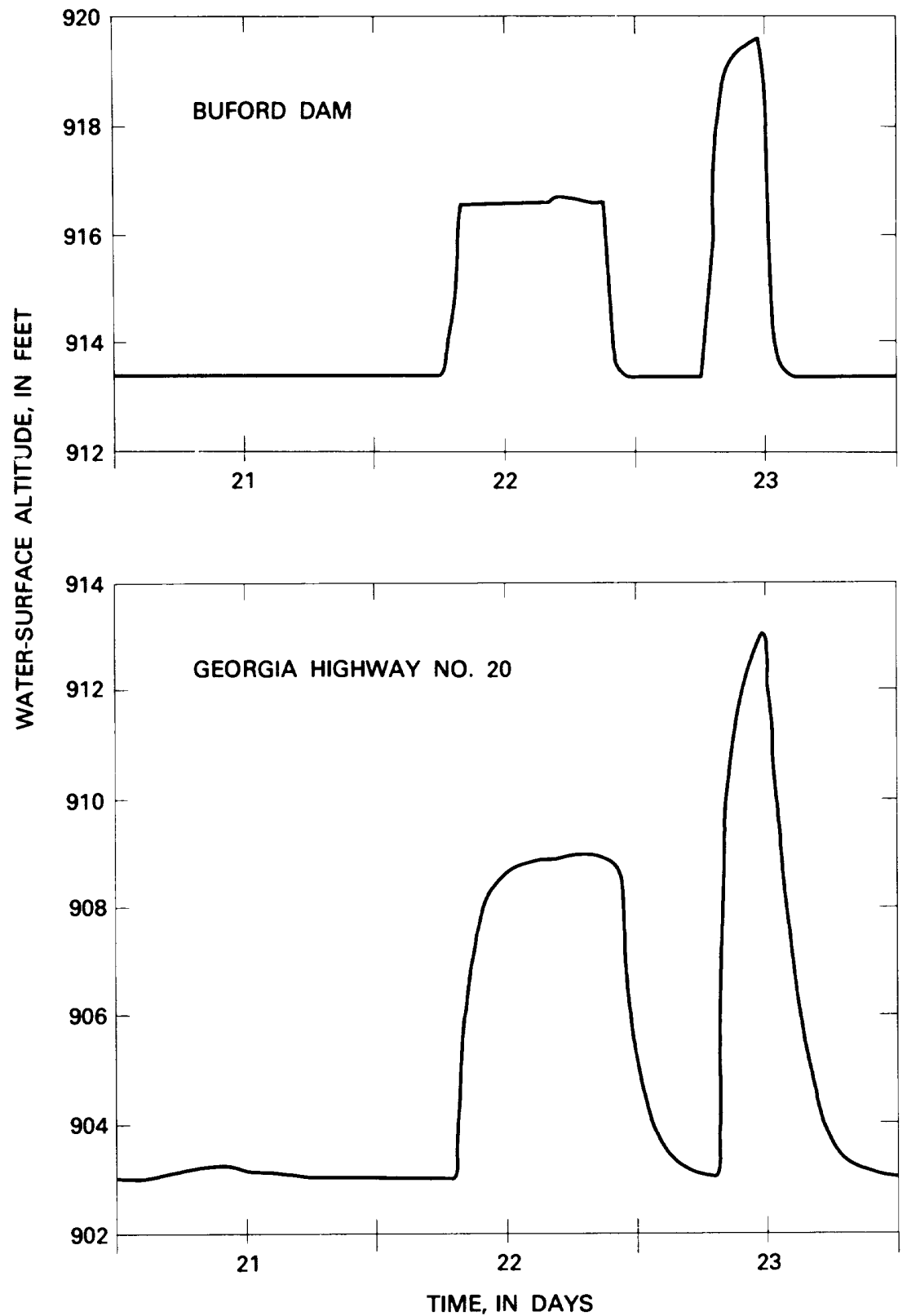

FigUre 3.-Measured stage of the Chattahoochee River at Georgia Highway 20, March 21-23, 1976. 
Figure 4.--Measured stage of the Chattahoochee River at Littles Ferry Bridge, March 21-23, 1976.

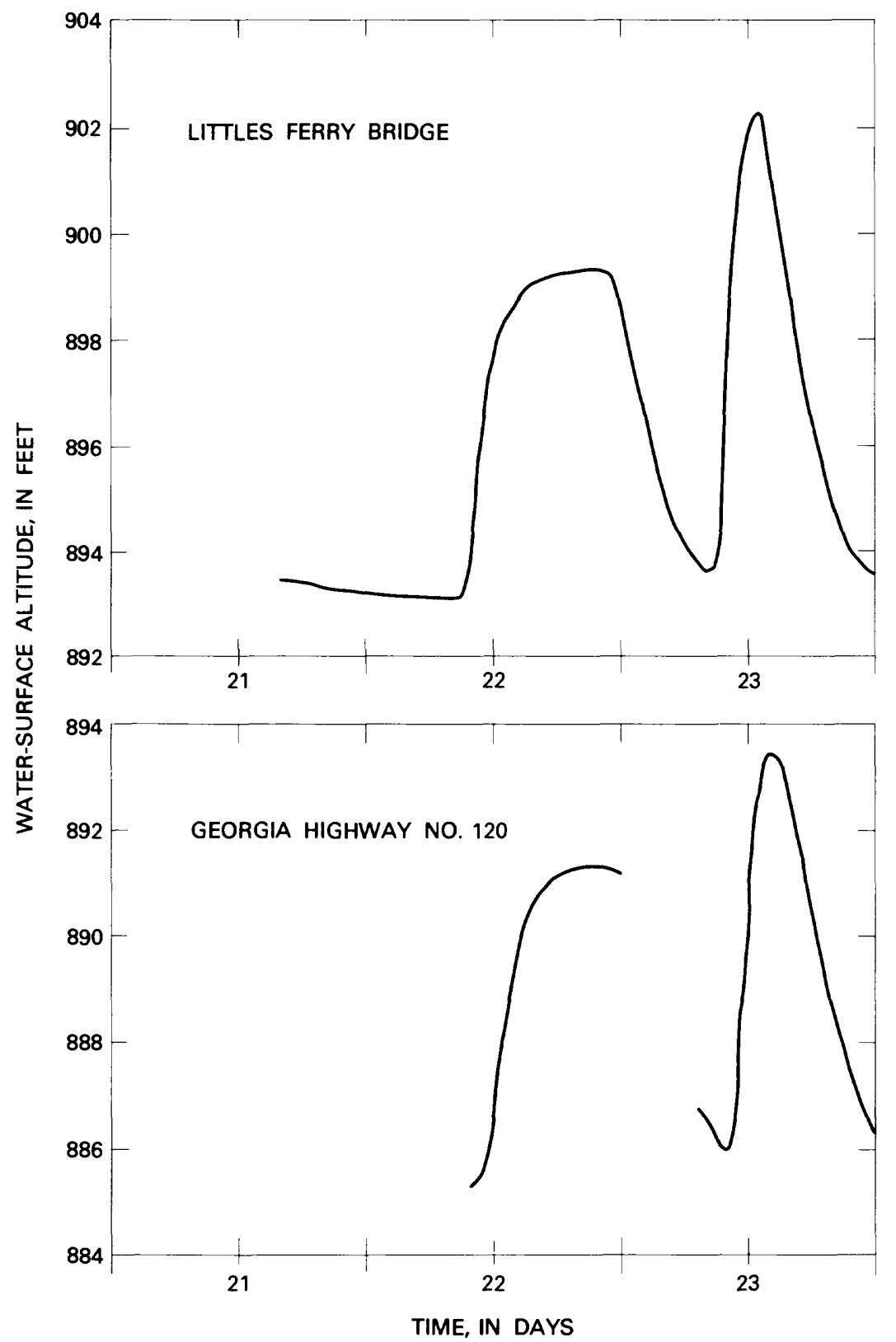

Figure 5.-Measured stage of the Chattahoochee River at Georgia Highway 120, March 21-23, 1976. 


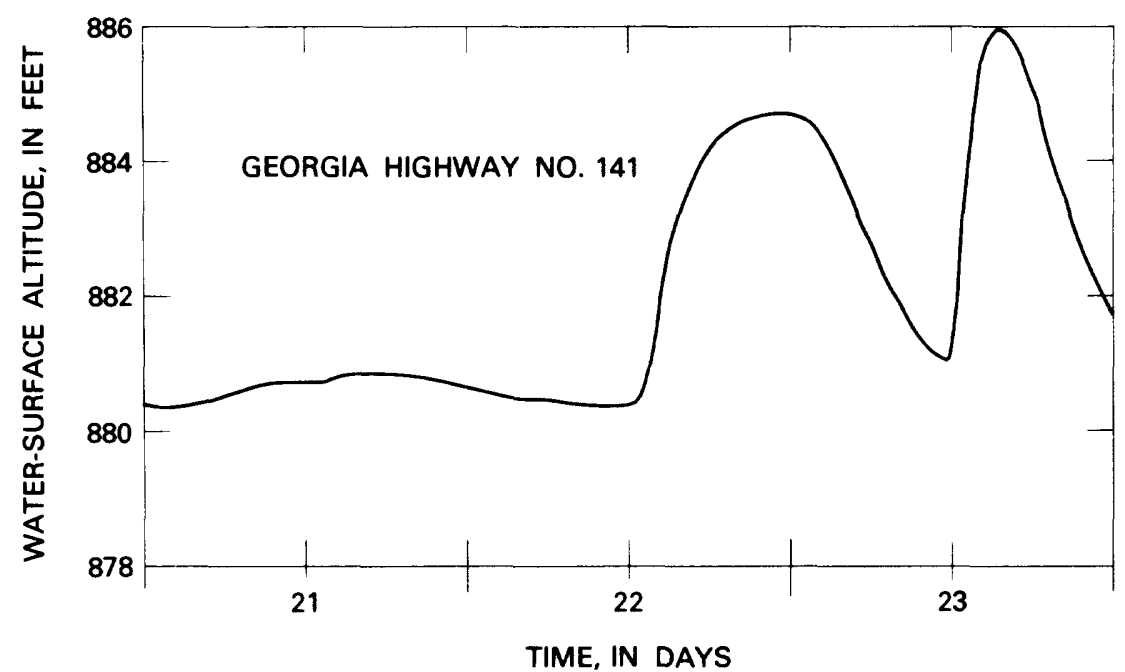

Figure 6.-Measured stage of the Chattahoochee River at Georgia Highway 141, March 21-23, 1976.

section location. The altitude of the water surface with respect to datum was then determined and the depth of flow across the section was measured by sounding or with a Fathometer. Measurements of the section above the water surface were made using standard leveling and stadia techniques. Cross-section coordinates at nine locations were obtained from the U.S. Army Corps of Engineers (1973). All cross-section data used in this study are listed in the summary of data (table 13).

\section{CHANNEL CHARACTERISTICS}

\section{GEOMETRY}

Typical river cross sections are shown on figure 11 . The general shape of each section is rectangular with an irregular bed and high steep banks. Channel widths range from about 150 to 300 feet. No trends in width or shape were observed with distance down the reach.

A longitudinal profile of the thalweg altitude at each cross section is shown in figure 12. Several discontinuities occur in the profile most notably near the confluence with James Creek, at Littles Ferry Bridge, and upstream of the Gwinnett County water-supply intake. At each location, the low point of the discontinuity is proximate to large-scale dredging or pumping operations which have probably scoured the channel bottom. 
FIGURE 7 (left).-Measured discharge in the Chattahoochee River at Georgia Highway 20, March 21-23, 1976.

Figure 8 (right).-Measured discharge in the Chattahoochee River at Littles

Ferry Bridge, March 21-23, 1976.

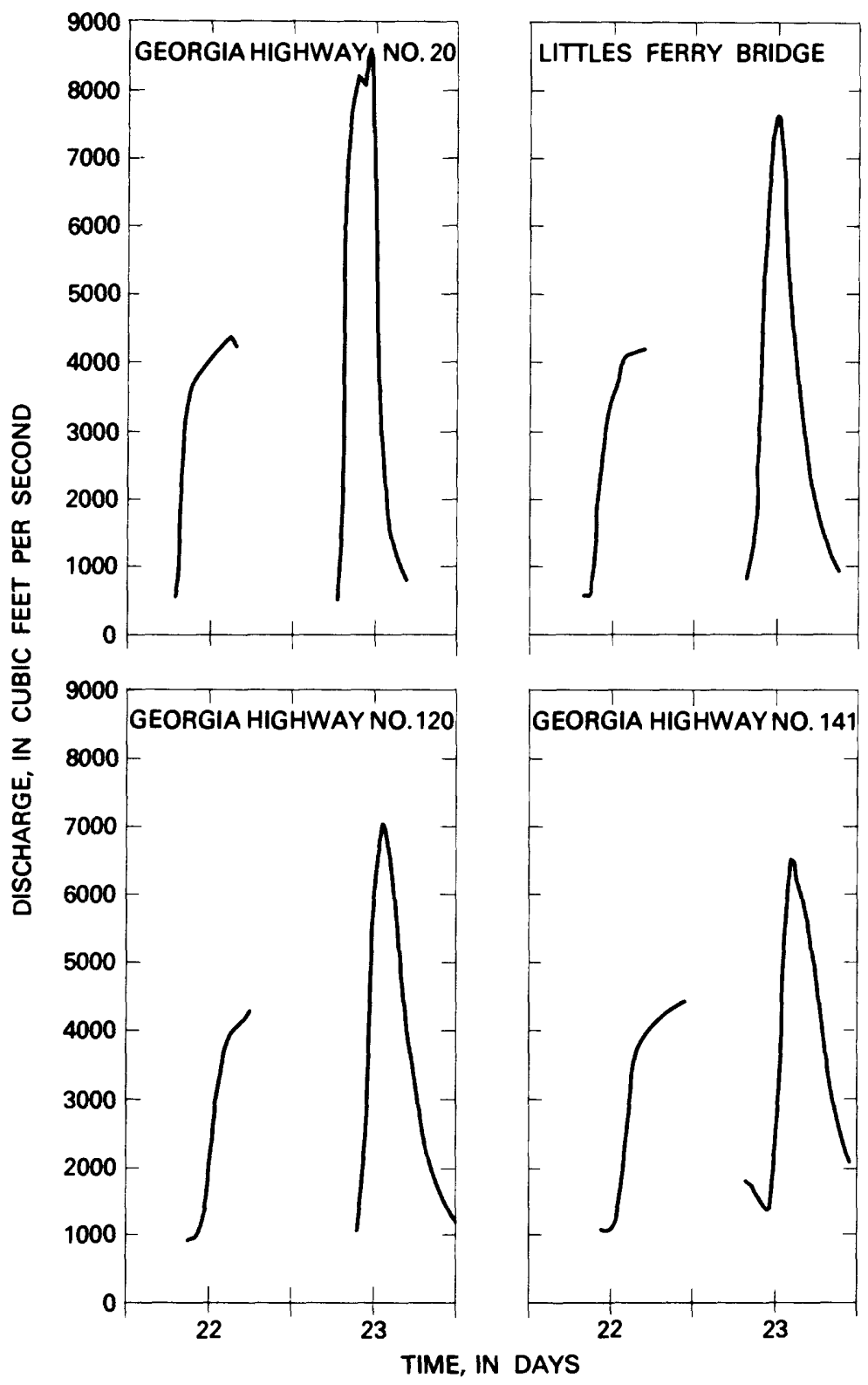

FIGURE 9 (left).-Measured discharge in the Chattahoochee River at Georgia Highway 120, March 21-23, 1976.

Figure 10 (right).-Measured discharge in the Chattahoochee River at Georgia Highway 141, March 21-23, 1976. 


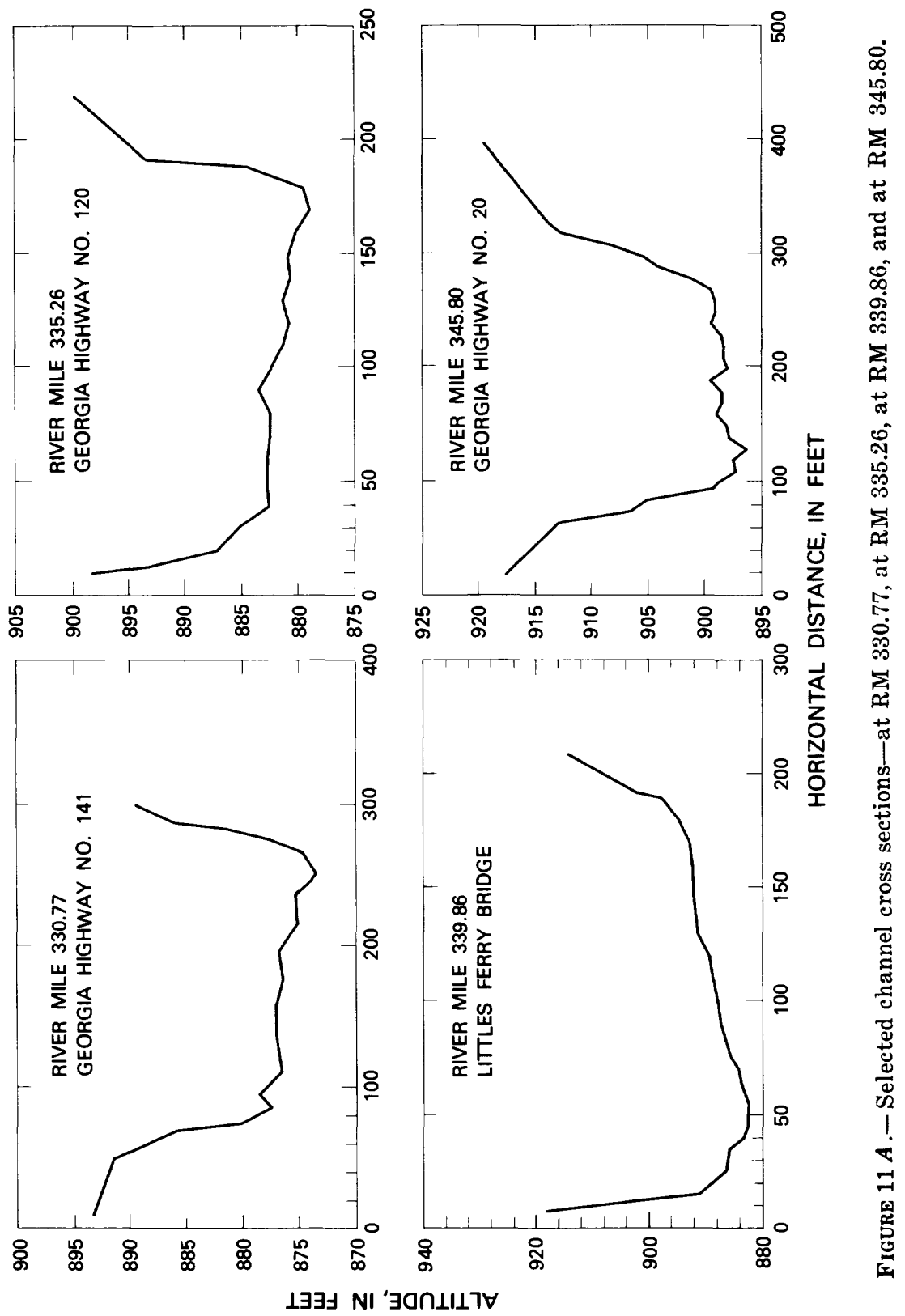




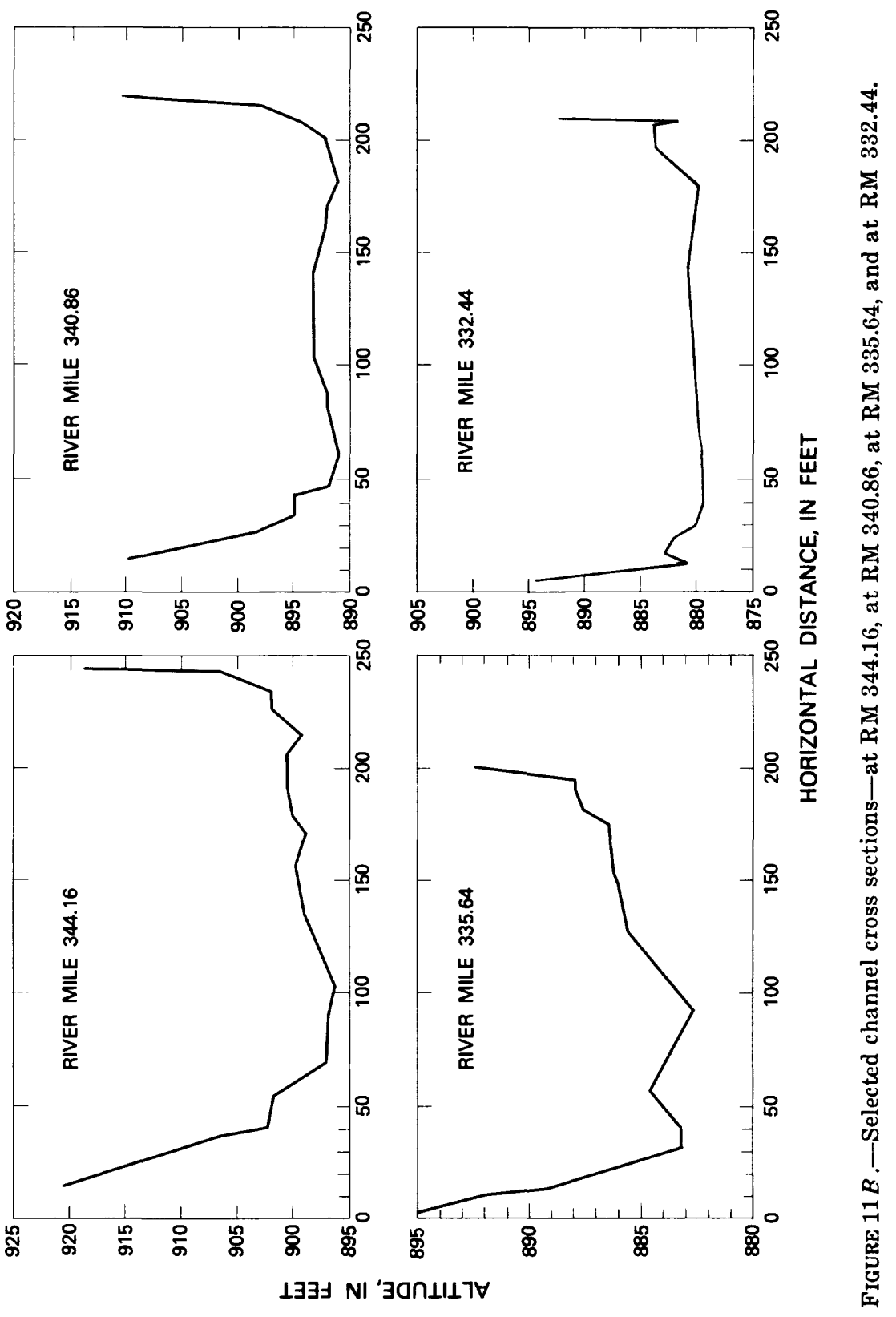




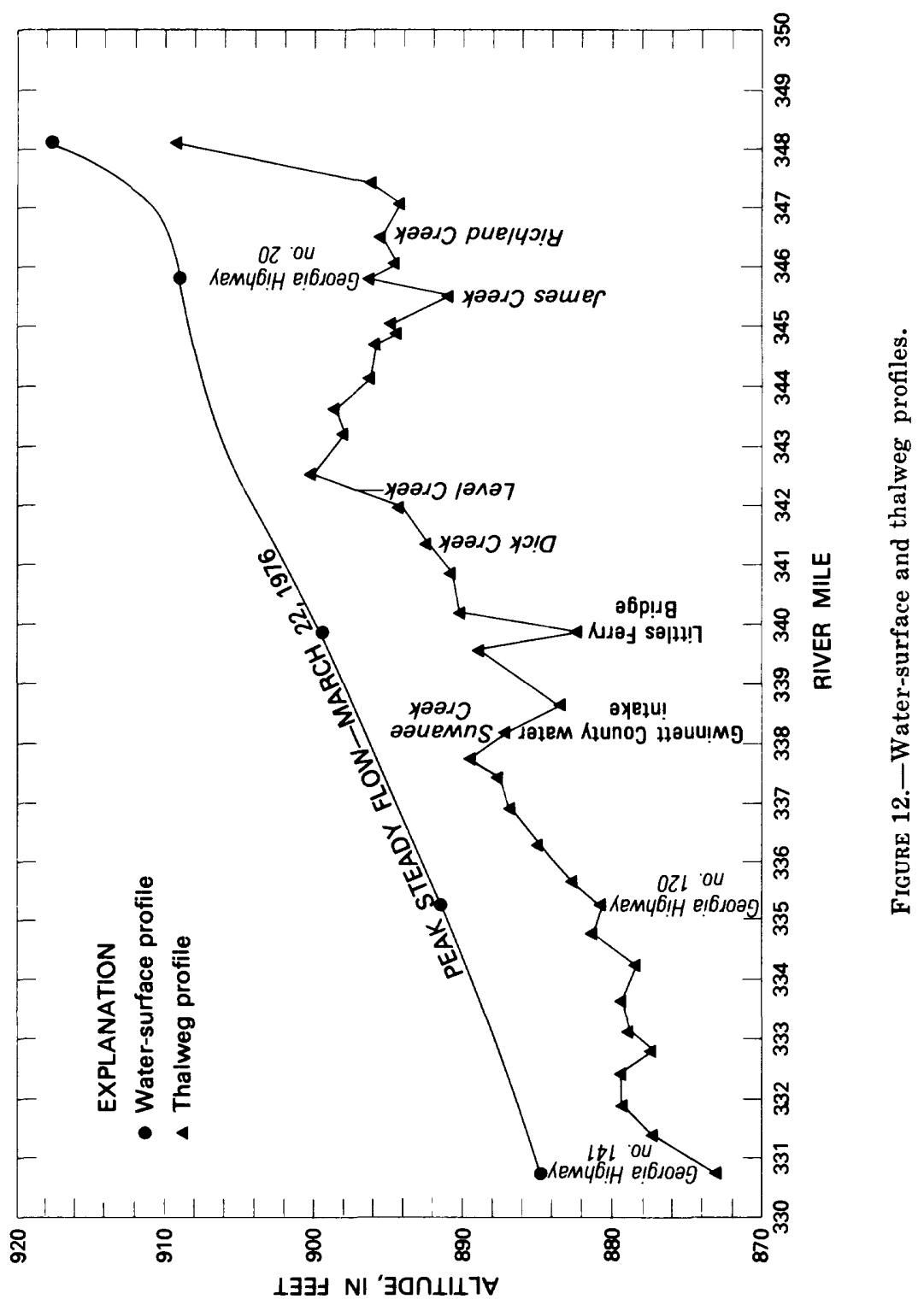




\section{ROUGHNESS}

Channel roughness is represented by Manning's roughness coefficient $(n)$ and was computed using the relation

$$
n=\frac{1.49}{V} S_{o}^{1 / 2} R^{1 / 3}
$$

in which $n=$ Manning's roughness coefficient, in $\mathrm{TL}^{-1 / 3} ; S_{o}=$ effective channel slope, in $\mathrm{LL}^{-1} ; V=$ mean flow velocity, in $\mathrm{LT}^{-1}$; and $R=$ hydraulic radius, in $\mathrm{L} . \mathrm{L}$ and $\mathrm{T}$ respectively indicate units of length and time. The constant 1.49, in inch-pound units, becomes 1.0 in metric units. The computation of channel roughness using equation (1) is only valid when flow conditions are steady or nearly steady. The discharge hydrographs (figs. 7-10) indicate such conditions occurred three times during the period of measurement, during most of March 21 and during the peak discharges of March 22 and 23. Roughness coefficients computed at these times at each discharge measuring station are listed in table 2. With the exception of values at Georgia Highway 120, computed roughness coefficients are highly sensitive to depth of flow. The range of $n$ values at individual stations is greatest at Georgia Highway 20 (0.044-0.089) and least at Georgia Highway 120 (0.036-0.039). Effective channel slopes used in the roughness computations were computed from the water-surface profile developed for peak steady flow on March 22 (fig. 12).

\section{FLOW CHARACTERISTICS}

Dynamic flow in the study reach is typified by the data collected on March 22 and 23. Stage and discharge data (tables 10 and 11) indicate that the flow at each station is most dynamic on the rising limb of the hydrograph and becomes increasingly less dynamic with increasing distance from Buford Dam. Maximum observed rates of change for both stage and discharge noted on March 23 are listed in table 3 and are shown to range, respectively, from $12.5 \mathrm{ft} / \mathrm{h}$ (feet per hour) and 10,400 ft $3 / \mathrm{s} / \mathrm{h}$ (cubic feet per second per hour) at Georgia Highway 20 to $2.3 \mathrm{ft} / \mathrm{h}$ and $2,620 \mathrm{ft}^{3} / \mathrm{s} / \mathrm{h}$ at Georgia Highway 141.

\section{STAGE-DISCHARGE RELATIONS}

The stage hydrographs shown in figures 2 to 5 indicate that hydropower flows are essentially waves translating through the reach. Peak wave discharge and wave attenuation are shown to 


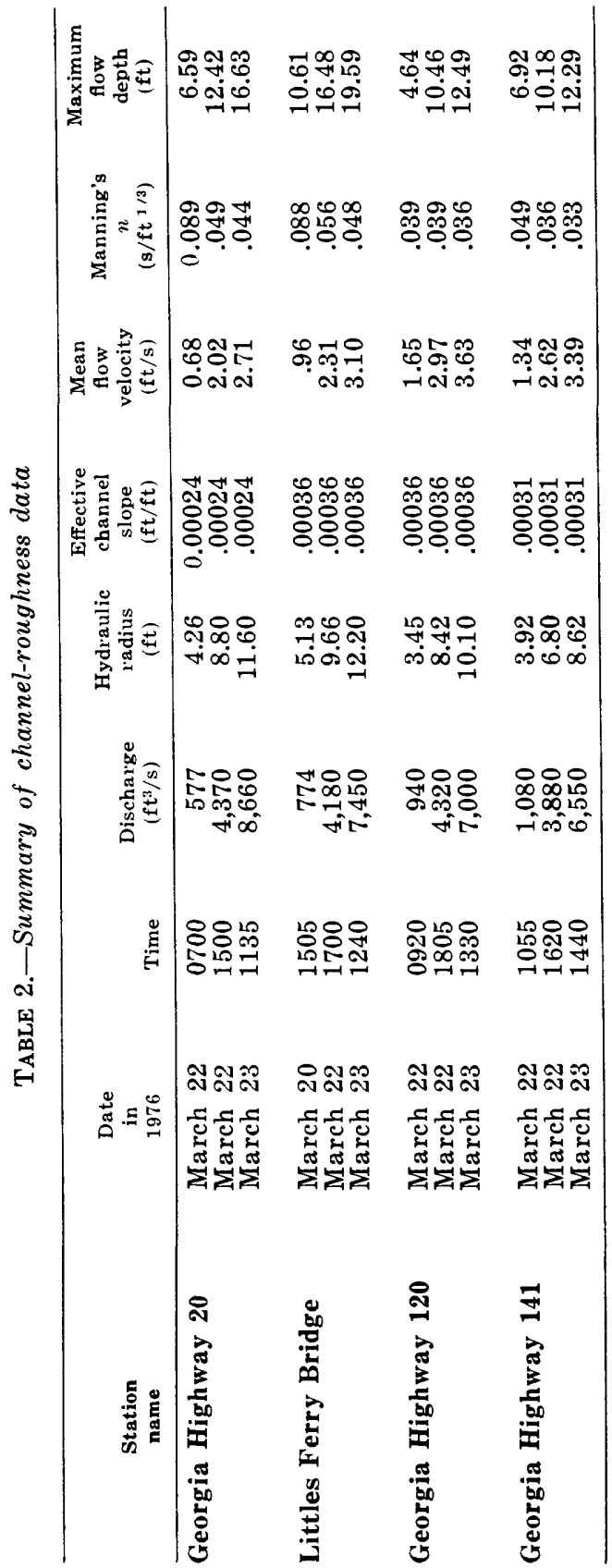


decrease and increase respectively with increasing distance from Buford Dam. Such waves, for the most part, resemble flood waves as described by Chow (1959), Fread (1975), and other investigators (see Selected References) and are characterized by hysteretic stage-discharge relations. Hysteretic relations were also noted for data collected during this study and are shown for the wave of March 23 on figures 13 to 16. The single-value discharge based on the current (1976) rating curve at Georgia Highway 141 is also shown on figure 16. The maximum width and area of each loop are listed in table 4 and are shown to progressively decrease in the downstream direction. At Georgia Highway 20, for example, the maximum loop width is equivalent to $3,200 \mathrm{ft}^{3} / \mathrm{s}$ while the corresponding value at Georgia Highway 141 is only 1,150 $\mathrm{ft}^{3} / \mathrm{s}$. Loop areas for the four stations range from about 15,000 $\mathrm{ft}^{4} / \mathrm{s}$ at Georgia Highway 20 to about $4,200 \mathrm{ft}^{4} / \mathrm{s}$ at Georgia Highway 141.

The stage-discharge hysteresis relation is a direct function of the dynamic nature of the wave or pulse which, in turn, depends upon the spatial rates of change of flow velocity and depth and the time rate of change of velocity. The greater these rates of change the more dynamic is the flow and the greater the hysteresis. Where the spatial and time rates of change of flow velocity are small or negligible compared to the spacial rate of change of depth, discharge is mostly a function of storage changes in the channel and can be described by considering the conservation of mass.

TABLE 3.-Maximum rates of change of stage and discharge on March 23, 1976

\begin{tabular}{lcc}
\hline $\begin{array}{c}\text { Station } \\
\text { name }\end{array}$ & $\begin{array}{c}\text { Maximum rate } \\
\text { of stage change } \\
(\mathrm{ft} / \mathrm{h})\end{array}$ & $\begin{array}{c}\text { Maximum rate } \\
\text { of discharge change } \\
\left(\mathrm{ft}^{3} / \mathrm{s} / \mathrm{h}\right)\end{array}$ \\
\hline Buford Dam & 22.8 & - \\
Georgia Highway 20 & 12.5 & 10,400 \\
Littles Ferry Bridge & 5.5 & 5,580 \\
Georgia Highway 120 & 4.1 & 3,860 \\
Georgia Highway 141 & 2.3 & $\mathbf{2 , 6 2 0}$ \\
\hline
\end{tabular}

TABLE 4.-Maximum widths and areas of hysteretic stage-discharge relations on March 23, 1976

\begin{tabular}{lcc}
\hline $\begin{array}{c}\text { Station } \\
\text { name }\end{array}$ & $\begin{array}{c}\text { Loop } \\
\text { area } \\
\left(\mathrm{ft}^{4} / \mathrm{s}\right)\end{array}$ & $\begin{array}{c}\text { Maximum } \\
\text { loop } \\
\text { width } \\
\left(\mathrm{ft}^{\mathrm{t}} / \mathrm{s}\right)\end{array}$ \\
\hline $\begin{array}{l}\text { Georgia Highway 20 } \\
\text { Littles Ferry Bridge }\end{array}$ & $\begin{array}{c}15,000 \\
\mathbf{1 2 , 0 0 0}\end{array}$ & 3,200 \\
Georgia Highway 120 & 7,750 & 1,900 \\
Georgia Highway 141 & 4,200 & 1,800 \\
\hline
\end{tabular}


Figure 13.-Hysteretic stage-discharge relation at Georgia Highway 20 on March 23, 1976-0705 to 1720 hours.

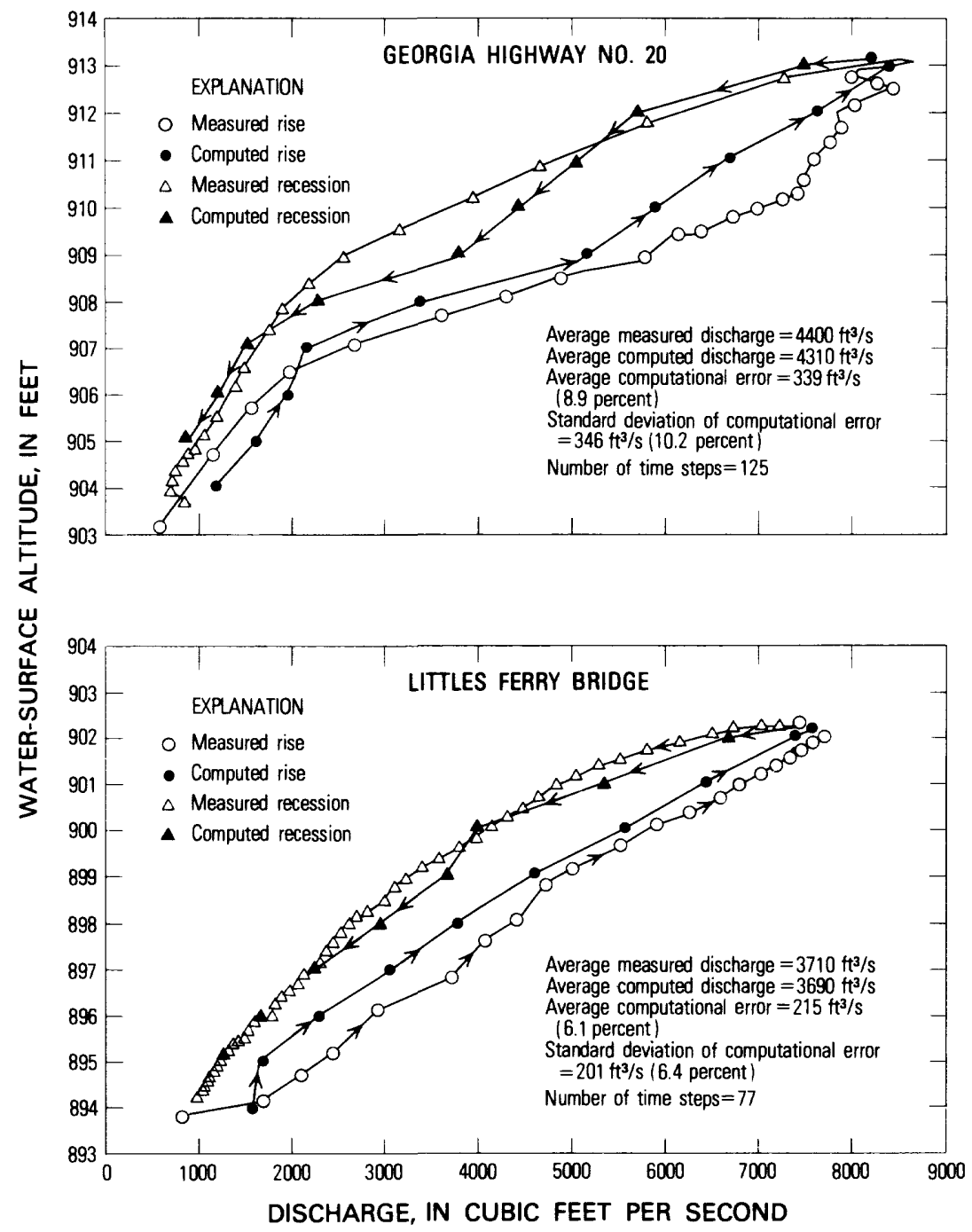

Figure 14.-Hysteretic stage-discharge relation at Littles Ferry Bridge on March 23, 1976-0850 to 2110 hours. 
FIGURE 15.--Hysteretic stage-discharge relation at Georgia Highway 120 on March 23, 1976-1005 to 2355 hours.

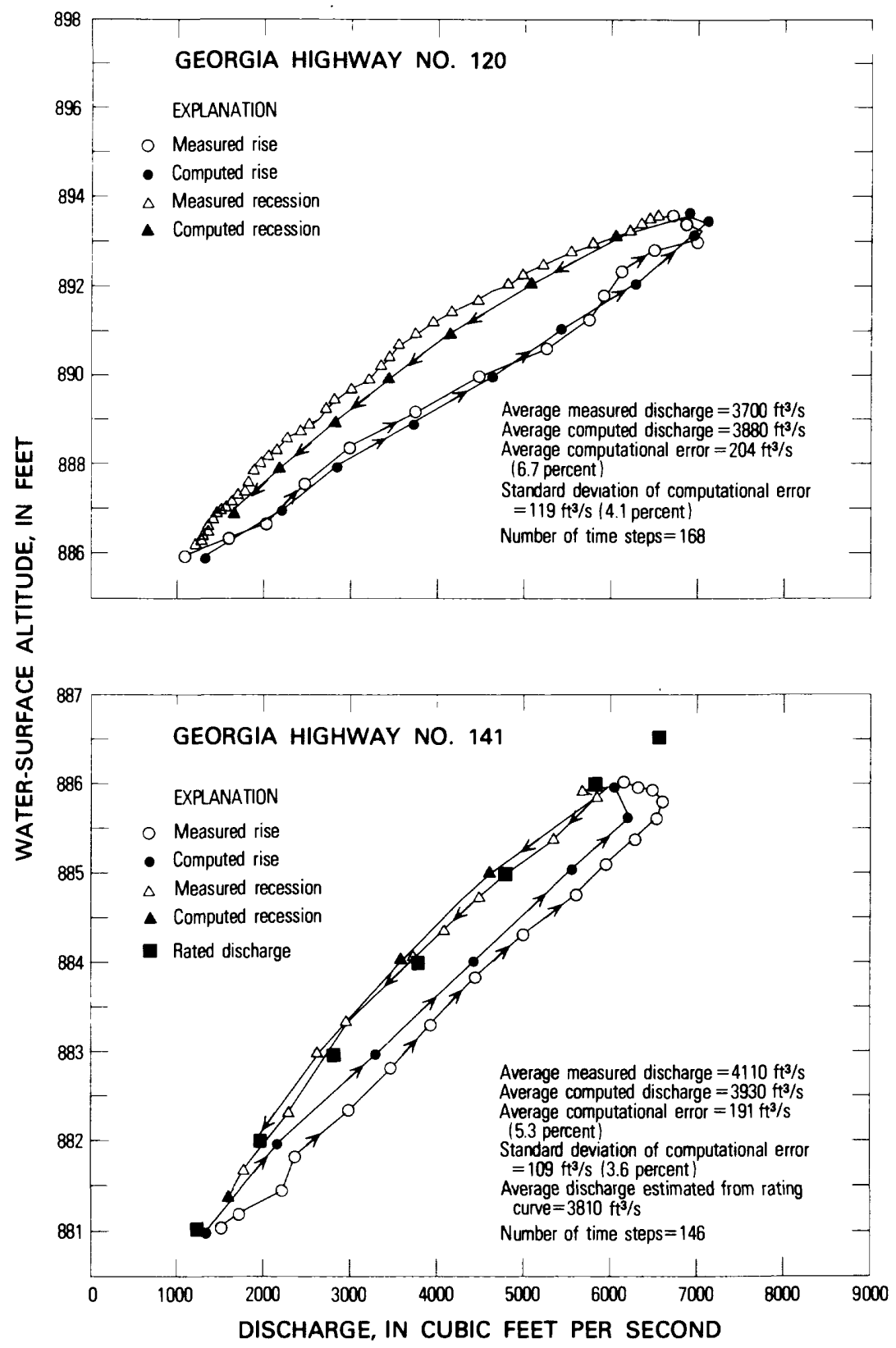

Figure 16.-Hysteretic stage-discharge relation at Georgia Highway 141 on March 23, 1976-1105 to 2310 hours. 


\section{WAVE VELOCITY}

The computed absolute velocities of waves translating through the study reach on March 22 and 23 are listed in table 5. Absolute velocities are defined by Chow (1959) as

$$
V_{w}=V+c \text {, }
$$

in which $V_{w}=$ absolute wave velocity, in $\mathrm{L} / \mathrm{T} ; V=$ the undisturbed velocity of the water through which the wave is propagated, in $\mathrm{L} / \mathrm{T}$; and $c=$ wave celerity, in $\mathrm{L} / \mathrm{T}$. All wave-velocity measurements were determined by (1) dividing the distance between the gaging station at Buford Dam and each respective downstream station by (2) the time difference between the beginning of stage rise at Buford Dam and the corresponding rise at each station. Absolute velocities through the reach are shown to range from about $11 \mathrm{ft} / \mathrm{s}$ to Georgia Highway 20 to about $5 \mathrm{ft} / \mathrm{s}$ to Georgia Highway 141. Small day-to-day differences in wave velocity are probably due to variations in initial flow velocities $(V)$.

TABLE 5.-Summary of absolute wave-velocity data

\begin{tabular}{ccc}
\hline & \multicolumn{2}{c}{ Wave velocity, in $\mathrm{ft} / \mathrm{s}$} \\
\cline { 2 - 3 } Station & March 22, & March 23, \\
name & 1976 & 1976 \\
\hline Georgia Highway 20 & 10.12 & 11.24 \\
Littles Ferry Bridge & 5.49 & 5.90 \\
Georgia Highway 120 & 5.38 & 5.74 \\
Georgia Highway 141 & 5.43 & 5.75 \\
\hline
\end{tabular}

\section{VELOCITY DISTRIBUTIONS}

The lateral distribution of mean velocity during the peak discharge of March 23, is shown for 4 stations on figures 17 to 20 . A nonuniform velocity distribution occurs at each station and is caused, for the most part, by cross-section geometry, channel roughness, and bridge characteristics-in particular, the number and spacing of bridge piers. Because discharge could only be measured at bridge sites, the velocity distributions shown are considered representative of only a short reach of the channel in the vicinity of the designated station.

Estimates of kinetic energy and momentum based on mean flow velocity in rough, natural channels are generally biased low because of nonuniform velocity distributions. To compensate for this bias, in one dimensional problems, the term describing the convective acceleration of unsteady flow (see eq. 5, p. 23) is multiplied by an energy or momentum coefficient. The theoretical development of these coefficients is summarized by Chow (1959, p. 29) and is based on a logarithmic distribution of velocity with 
TABLE 6.-Energy and momentum coefficients

\begin{tabular}{lcc}
\hline \multicolumn{1}{c}{ Station name } & $a$ & $\beta$ \\
\hline Georgia Highway 20 & 1.67 & 1.38 \\
Littles Ferry Bridge & 1.02 & 1.01 \\
Georgia Highway 120 & 1.21 & 1.09 \\
Georgia Highway 141 & 1.17 & 1.07 \\
\hline
\end{tabular}

depth during turbulent flow. Approximate energy and momentum coefficients can be computed using the formulas

$$
\begin{aligned}
& \alpha=1+3 \epsilon^{2}-2 \epsilon^{3} \\
& \beta=1+\epsilon^{2},
\end{aligned}
$$

in which $\alpha=$ the energy coefficient, $\beta=$ the momentum coefficient and $\epsilon=$ the ratio of maximum to mean channel velocity minus one. Values of $\alpha$ and $\beta$ equal to unity indicate a uniform velocity distribution. Energy and momentum coefficients computed using these formulas and the data shown on figures 17 to 20 are listed in table 6. Both coefficients are greatest at Georgia Highway 20.

\section{METHOD OF COMPUTING HIGHLY DYNAMIC FLOW AT A GAGED STATION}

Although the dynamic flows described in the previous section were caused by structural regulation, they are nevertheless similar to flows observed by hydrologists and engineers during floods in natural rivers and during rapid rainfall runoff from urban areas. Frequently, only a stage record of such flows is available and estimates of instantaneous and mean dynamic discharge are based on a rating curve or other single-value relation; that is, a relation based on a unique, one-to-one correspondence between depth and discharge. The hysteretic relation of stage to discharge indicates that estimates of instantaneous dynamic discharge based on rating curves can be significantly in error (fig. 16). On the other hand, estimates of mean dynamic discharge based on rating curves may not be so severely affected by hysteresis because integration of the underestimated flow during rising stages is frequently compensated for by a corresponding overestimate during falling stages.

Accurate definition of instantaneous stream discharge is critical to many hydrologic investigations. At many stations, for example, the water quality of a stream is fundamentally related to discharge. However, during periods of highly dynamic flow, stream discharge measurements made in conjunction with the collection of water-quality data are generally not representative of the discharge at the time of sampling. Such situations occur frequently 
Figure 17.-Lateral velocity distribution at Georgia Highway 20 during peak discharge, March 23, 1976.

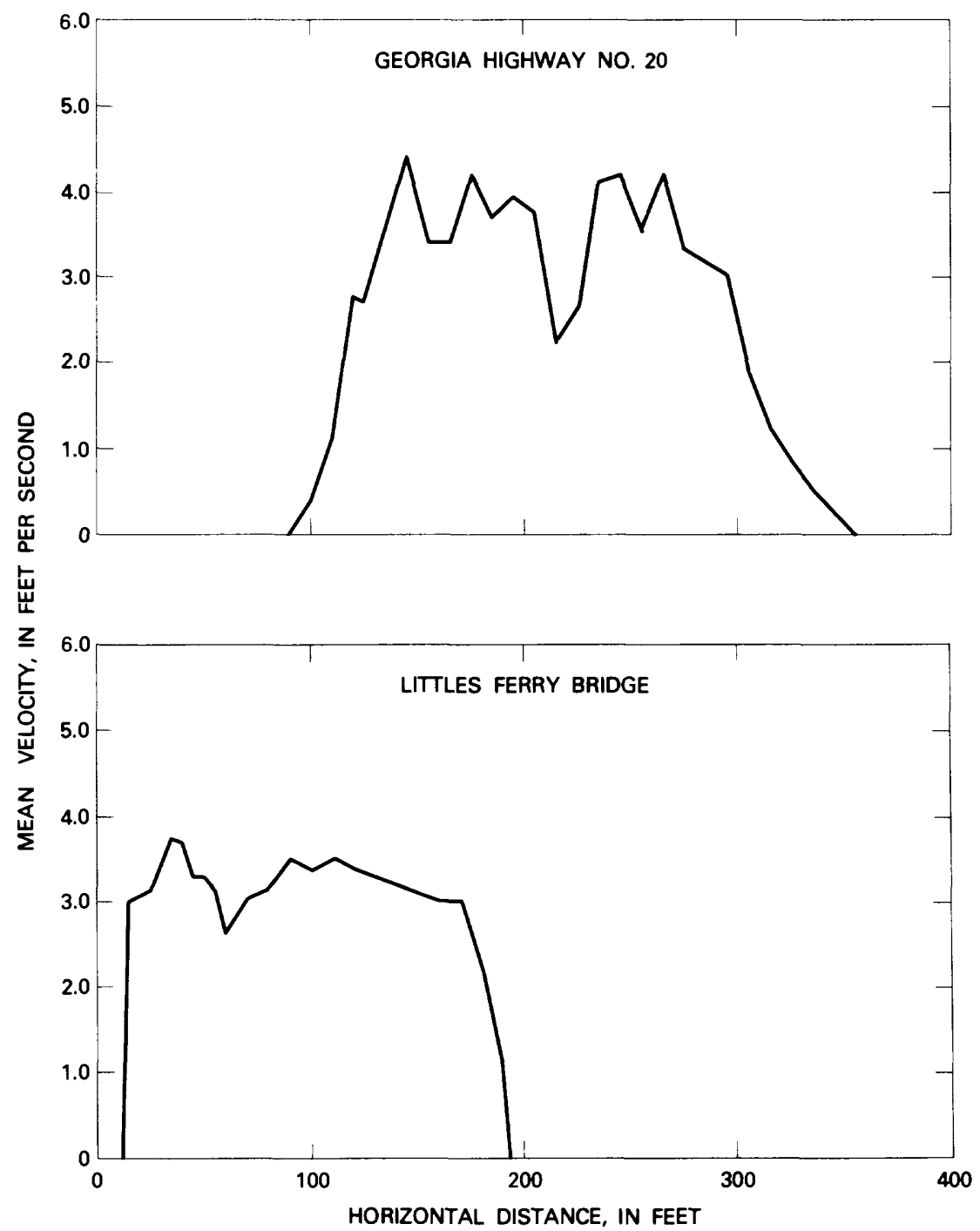

Figure 18.-Lateral velocity distribution at Littles Ferry Bridge during peak discharge, March 23, 1976.

on "flashy" urban streams. Thus, the interpretive value of expensive and generally accurate chemical analyses is either biased or distorted because of nonrepresentative discharge data. Similar bias occurs at gaging stations where stage hydrographs of dynamic flows are used in conjunction with rating curves to estimate 
Figure 19.-Lateral velocity distribution at Georgia Highway 120 during peak discharge, March 23, 1976.

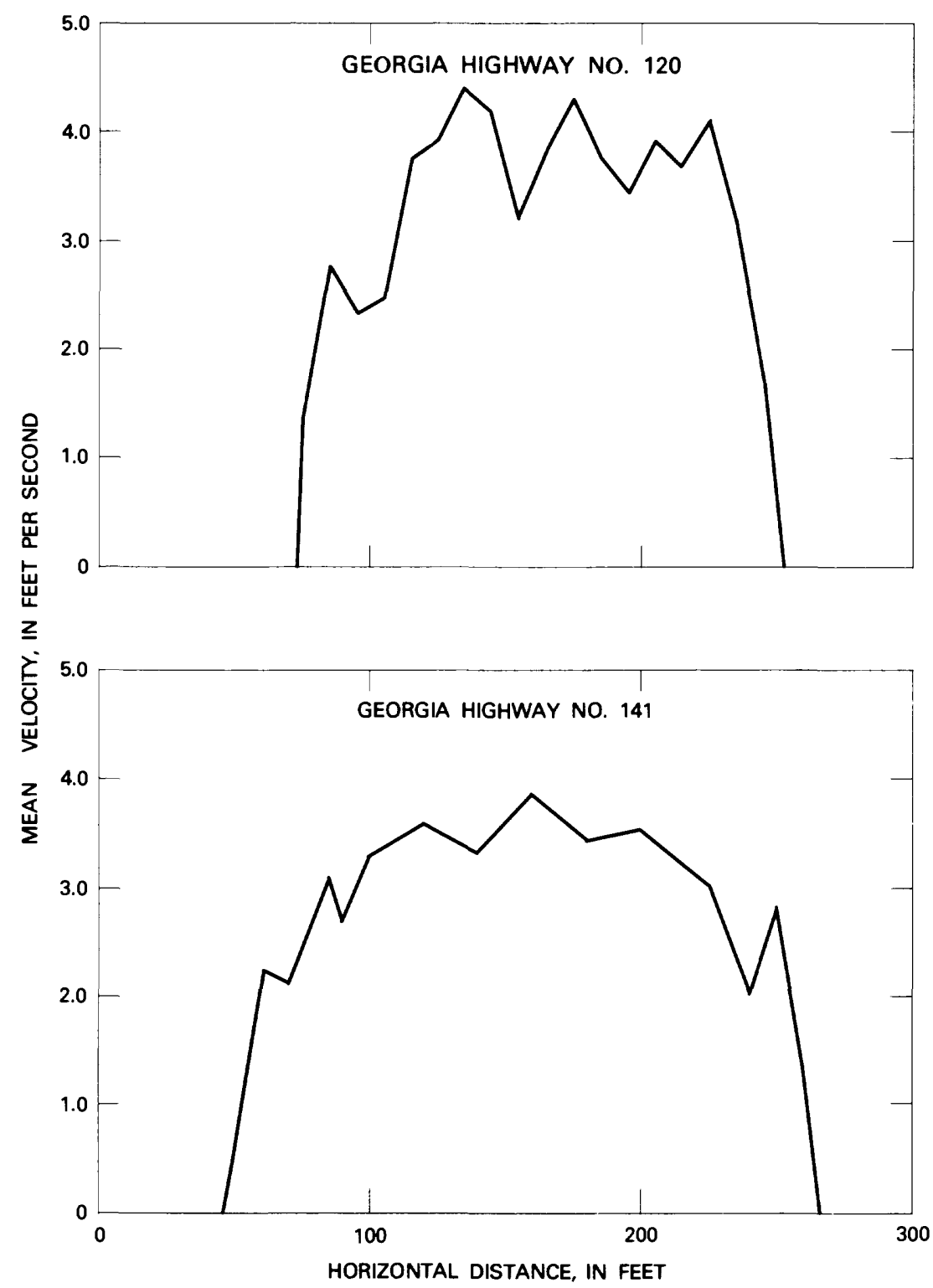

Figure 20.-Lateral velocity distribution at Georgia Highway 141 during peak discharge, March 23, 1976.

the storm load of water-quality constituents.

Clearly, then, a method which utilizes stage data, to accurately compute instantaneous dynamic discharge at a gaging station 
can be applied to a variety of hydrologic studies. One such method was developed by Fread (1975) and demonstrated for large, relatively "sluggish" streams such as the Mississippi and Atchafalaya Rivers in Louisiana. The root mean square error between observed instantaneous flood discharges in these rivers and corresponding discharges computed by Fread's model ranged from about 3 to 7 percent. The application of Fread's model, however, is limited to large rivers with generally prismatic channels and small channel slopes where the bulk of the flood wave moves approximately as a kinematic wave. Discharge produced by a kinematic wave is characterized by nearly parallel energy and channel slopes and can be reasonably described by considering the conservation of mass (Lighthill and Whitham, 1955). Such relations do not characterize flow conditions in the study reach of the Chattahoochee River nor do they apply to flow conditions in many urban streams which are subject to rapid and extensive runoff from streets and other impermeable surfaces.

The remainder of this paper discusses the development and application of a mathematical model which accurately computes highly dynamic discharge at a river station using only the stage record and channel characteristics pertaining to that station. Development of the model is based on a direct solution of the equations describing gradually varied, unsteady flow in open-channels as described by Chow (1959). These equations are transformed to describe mean flow velocity in a short reach of the channel proximate to the gaging station. Assumptions used to develop the model include:

1. the channel geometry of the short reach is permanent;

2. lateral flow to or from the stream is negligible in the vicinity of the station;

3. Manning's equation describes energy losses in the short reach due to turbulence and channel roughness; and

4. the shape of the wave profile remains stable as it translates downstream.

The final form of the model is similar to Fread's but is more general and more applicable to highly dynamic flows.

Application of the model utilizes the stage and discharge data collected on March 23, 1976 at 4 stations on the Chattahoochee River (table 1). Statistical comparisons of observed and computed discharge provide mean computation error and standard deviation of this error at each station. Sensitivity analyses of various model parameters provides some insight into the relation between channel and flow parameters and highly dynamic discharge. 
MODEL DEVELOPMENT

Chow (1959) lists the equations describing gradually varied, one-dimensional, unsteady flow in open channels as

$$
\begin{gathered}
\frac{\partial y}{\partial x}+\frac{\alpha V \partial V}{g \partial x}+\frac{1 \partial V}{g \partial t}=S_{o}-S_{f} \\
D \frac{\partial V}{\partial x}+V \frac{\partial y}{\partial x}+\frac{\partial y}{\partial t}=O
\end{gathered}
$$

in which $x=$ the distance along the channel, in $\mathrm{L} ; y=$ the watersurface altitude, in $\mathrm{L} ; t=$ time, in $\mathrm{T} ; g=$ the acceleration due to gravity, in $\mathrm{LT}^{-2} ; V=$ the mean flow velocity, in $\mathrm{LT}^{-1} ; \alpha=$ the energy coefficient; $D=$ the hydraulic depth, in L; $S_{o}=$ the effective channel slope, in $\mathrm{LL}^{-1}$; and $S_{f}=$ the energy slope, in $\mathrm{LL}^{-1}$. Equations (5) and (6) are commonly known as the momentum and continuity equations, respectively. Terms of the momentum equation are dimensionless and include, from left to right, the gradients of pressure, convective acceleration, temporal acceleration, gravity and total stream energy. Terms of the continuity equation are dimensioned in $\mathrm{LT}^{-1}$ and collectively define the conservation of mass in the channel. Note that two of the partial derivatives are spatial and thus depend on a description of flow conditions along the channel. The remaining derivatives are temporal and depend only on a characterization of flow at a particular stream station.

Simultaneous addition of equations (5) and (6) removes $\frac{\partial V}{\partial x}$ from consideration and provides one equation of the form.

$$
\left(D-\frac{\alpha V^{2}}{g}\right) \frac{\partial y}{\partial x}-\frac{\alpha V}{g} \frac{\partial y}{\partial t}+\frac{D}{g} \frac{\partial V}{\partial t}=D\left(S_{o}-S_{f}\right) .
$$

Stage measurements (figs. 2 to 6 ) indicate that the general form of the wave profile remains generally stable while translating through the study reach. Under such conditions, the pressure gradient $\partial y / \partial x$ can be approximated by a function of the absolute wave velocity and the rate of change of water-surface altitude. That is

$$
\frac{\partial y}{\partial x}=\frac{-1}{V_{w}} \frac{\partial y}{\partial t}
$$

Substitution of (8) into (7) leads to

$$
-\frac{D}{V_{10}} \frac{\partial y}{\partial t}+\frac{\alpha V^{2}}{V_{r} g} \frac{\partial y}{\partial t}-\frac{\alpha V}{g} \frac{\partial y}{\partial t}+\frac{D}{g} \frac{\partial V}{\partial t}=D\left(S_{n}-S_{f}\right) .
$$


Consider that energy losses from channel roughness and turbulence are described by Manning's equation. The energy slope can then be defined as

$$
S_{f}=\frac{V^{*} n^{2}}{2.22 R^{4 / 3}},
$$

which is a rearrangement of equation (1).

Substituting (10) into (9) and rearranging terms yields

$$
\frac{g}{V_{w}}-\frac{\alpha V^{2}}{V_{w} D}+\frac{\alpha V}{D} \frac{\partial y}{\partial t}-\frac{V^{2} n^{2} g}{2.22 R^{4 / 3}}+g S_{o}=\frac{\partial V}{\partial t} .
$$

Note that the spatial derivatives have now been removed and all remaining derivatives are with respect to time only. Thus equation (11) can be rewritten as

$$
\left(\frac{g}{V_{w}}-\frac{\alpha V^{2}}{V_{w} D}+\frac{\alpha V}{D}\right) \frac{d y}{d t}-\frac{V^{*} n^{2} g}{2.22 R^{1 / 3}}+g S_{o}=\frac{d V}{d t} .
$$

NUMERICAL ANALYSIS

Evaluation of equation (12) by finite-difference approximations leads to the following quadratic equation:

$$
\begin{gathered}
{\left[\frac{-\alpha\left(y_{i+1}-y_{i-1}\right)}{2 V_{w} D_{i}}-\frac{n^{2} g\left(t_{i}-t_{i-1}\right)}{2.22 R_{i}^{4 / 3}}\right] V_{i}{ }^{2}+\left[\frac{\alpha\left(y_{i+1}-y_{i-1}\right)}{2 D_{i}}-1\right] V_{i}} \\
+\left(t_{i}-t_{i-1}\right) g S_{o}+V_{i-1}+\frac{\left(y_{i+1}-y_{i-1}\right) g}{2 V_{w}}=0 .
\end{gathered}
$$

In equation (13), $d V$ and $d t$ are evaluated by backward-difference approximations and $d y$ is evaluated by a central-difference approximation. The subscript $i$ is a time-step index that varies with given values of $y$ and is never less than 2 .

For convenience the coefficient terms of equation (13) are symbolized as shown below

$$
\begin{aligned}
& a_{i}=\frac{-\alpha\left(y_{i+1}-y_{i-1}\right)}{2 V_{20} D_{i}}-\frac{n^{2} g\left(t_{i}-t_{i-1}\right)}{2.22 R_{i}^{4 / 3}} \\
& b_{i}=\frac{\alpha\left(y_{i+1}-y_{i-1}\right)}{2 D_{1}}-1 \\
& c_{i}=\left(t_{i}-t_{i-1}\right) g S_{o}+V_{i-1}+\frac{\left(y_{i+1}-y_{i-1}\right) g .}{2 V_{w}} .
\end{aligned}
$$

\section{COMPUTATION SCHEME}

Computation of dynamic discharge at a gaginig station using equation (13) is accomplished in two steps using a digital com- 
puter. Required stream channel data include values of Manning's $n$ and effective channel slope along with cross-section coordinates at the gage site. Data required relative to a particular flow event include a temporal distribution of water-surface altitude (stage record) and the mean flow velocity just prior to the beginning of stage rise. This velocity can either be measured or estimated from a stage-discharge rating and a stage-area relation for the gage site. Wave velocity must also be known and can be computed from concurrent stage records collected at two or more stations along the reach of interest or as the sum of initial velocity and celerity (eq. 2).

Step one of the computation scheme computes values of crosssectional area, top width, and wetted perimeter at each given water-surface altitude. These computations are based on the given cross-section coordinates which mathematically define an irregular polygon when part of the section is occupied by flow. The value of each flow-geometry parameter (area, top width, or wetted perimeter), therefore, can be computed directly from the following equation, which describes the area of an irregular polygon with any number of sides:

$$
\begin{aligned}
& 2 A=l_{1}\left(h_{2}-h_{m}\right)+l_{2}\left(h_{3}-h_{1}\right)+ \\
& \text {-.--- }+l_{m-1}\left(h_{m}-h_{m-2}\right)+l_{m}\left(h_{1}-h_{m-1}\right) \text {. }
\end{aligned}
$$

In equation (14), $A=$ the cross-sectional area of flow, in $\mathrm{L}^{2} ; h=$ the vertical component of a cross-section coordinate, in $\mathrm{L}$; $l=$ the horizontal component of a cross-section coordinate, in $\mathrm{L}$; and $m=$ the number of polygon sides or the number of coordinate pairs. Values of both $h$ and $l$ can be measured from any convenient datum and are easily obtained from standard dischargemeasurement notes. Subscripts for $h$ and $l$ are numbered consecutively from the leftmost or rightmost cross-section coordinate.

The solution of equation (14) utilizes a "floating coordinate" technique at the left and right boundaries of the section (polygon). These coordinates adjust with given values of water-surface altitude such that the upper side of the polygon always represents the water surface. Thus the $h$ component of the "floating" coordinates equals the water-surface altitude and the difference between corresponding $l$ components equals the top width. Direct solution of equation (14) provides the cross sectional area of flow at the given stage. The total distance between all coordinate points at or below the water surface equals the wetted perimeter. The velocity at the previous time step is always known. Thus coefficients $a_{i}, b_{i}$, and $c_{i}$, can now be computed and, with equation (12), form a second-degree polynomial equation in $V_{i}$. 


$$
a_{i} V_{i}^{2} b_{i} V_{i}+c_{i}=0
$$

Step two of the computation scheme solves equation (15) by applying a Newton-Raphson iteration technique. The mean flow velocity and initial water-surface altitude at time step one must be given and are the only flow boundaries required. Where sufficient data are available, changes in Manning's $n$ with depth must also be accounted for in the computation scheme. The instantaneous discharge at each time step is the product of the computed velocity (eq. 15) and the computed area (eq. 14).

A digital computer program written to solve equations (14) and (15) using the computation scheme discussed above is listed in table 7 .

\section{APPLICATION}

The stage and discharge data collected at Georgia Highways 20, 120, 141, and at Littles Ferry Bridge on March 23, 1976 were applied to the program listed in table 7 (p. 27-32). Initial mean flow velocities were obtained by direct measurement. Effective channel slopes at each station were computed from the watersurface profile generated during the sustained peak flow on March 22 (fig. 12, table 2). Manning's $n$ values used in the program are listed for each station in table 2 . Changes in channel roughness with depth at Georgia Highways 20 and 141 and at Littles Ferry Bridge were accounted for by linear interpolation between known values (table 2). At Georgia Highway 120, Manning's $n$ was held constant with depth at .039. Absolute wave velocities used in the program are those listed in table 5 for March 23, 1976. Energy coefficients used in the computation scheme are listed in table 6 .

Observed and computed hysteresis loops are shown on figures 13 to 16 . At each station the computed discharge closely approximates the measured discharge at most stages. Statistics indicating average error in units of flow and in percent are also listed. The average computation error was determined by summing the absolute difference between measured and computed discharges at each time step and dividing by the number of time steps. Values of average percentage error were similarly computed. For the three most downstream stations the average computation error was less than 6.7 percent; standard deviation of this error was 6.4 percent or less. At Georgia Highway 20 computed discharges were considerably less accurate, with an average computation error and standard deviation of 8.9 and 10.2 percent respectively. 
TABLE 7.-Digital program list

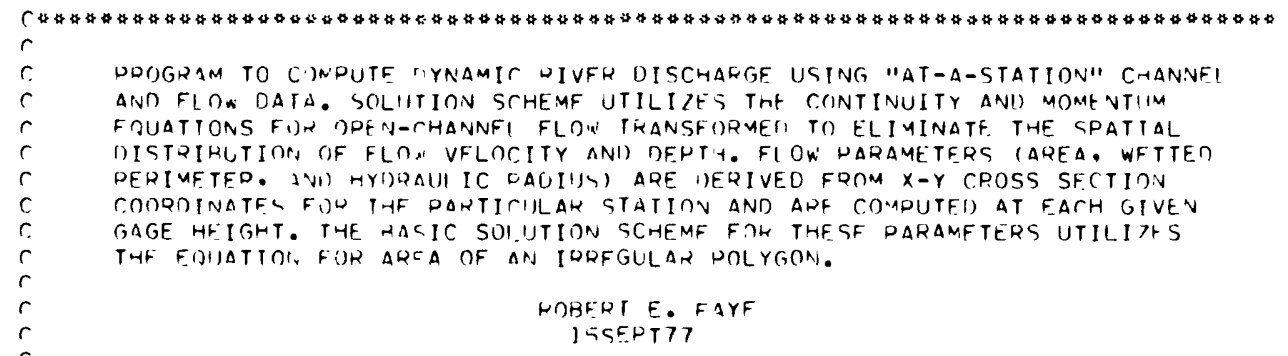

VANIARLE ITFFINITION

AA, RH. CC = COFFFICIEVTS OF MIJAURATIC EOUATION

AFPINT = INITIAL STUFAM COOSS SFCTIONAL ALFA

AL.PHA = VFLORITY CNFFFICIFNT

AMAN = COMPUTF, MANNINTSS N AT CONTROL DLTITURF

HOELEV. AOFI.FVI, HOFLEVL = HOTTOM FLEVATION OF C,HANNEL THAL,WFF,

CODE = VALTAHIF DESTGNAIOQ FOR SENSITIVITY ANALYSIS

I) $A T E=$ AFGIA,NIVG IATE OF I)ATA COLLFCTION

DFI T = TI IF 1)IFFELFA,CE DETWEFN STAISE MEASUREMENTS

IFF = CONATRIL ALTITIIOE FOL MANNING'S N INTERPOLATION

[IISCH = COAPIITEU DTCCHAKGF

$F=W A T F W-S L Q F A C F$ AI TITUT)F (STAGF)

FINT = INITIOI NATFF-SUHFACE ALTITIITF

FNARK = STAGL AT WHTCH CLISS-SFCTION GEOMETHY CHANGES SIGNIFITANTIY

FPS = CIOSIJUE. ERRITR FOR NFWTON-RAPHSON ITERATION

FRRQ = $\triangle R S O I \| T E$ DIFFFRENCF HFT NEEN COUPUITED AND MFASUREO DISCHARGF

FTA = NAR NINGS, A VAL.II

FTACPT = INTH RCEPT FOR MANNING OS IN COMPUTATION WITH IIFDTH

FTASL = SL ONF FOH MANAINGIS N COMPUTATION WITH DEPTH

GRAV = ACCELEWATION OF GRAVITY (3?.2 FT/SEC \&?)

HYIRAD = HYCOAAILIC JANIUS

HYDENT = HYURAJLIC IFOTH

NORUN = NUARFR OF DINS FOL SENSITIVITY ANALYSIS: FQUAALS ZERO IF

SENSITIVITY MIVALYSTS NOT DFOUIRED

NIJUEST = FDLI $S 1$ IF MANNTNGS II IS CONSTANT: OTHERWISF FUUALS LER:)

NOTMSO = NUVAFR OF STASE MFASIJIEMENTS (IE. NUMRED OF TIME STEPS)

NUMGN = NUMEEK OF COMNUTEI) MANNINGIS $N$ VALUES

NXY,NXYI,NXYZ = INUIHER OF $X, Y$ COOROINATE PAIRS FOR CHOSS SECTTON

PNCTFO = CONHIITATION FRROK IN DFQCENT

IJMFAS = MEASIILEI) DICCHAKGF AT STATION

RIVNII. = RIVE\& MILF OF STATION

RUS = STANITALO DEVIATION OF COMPUIATION ERRDR

DIASI = STANU(IANI) IJFVTATION OF PERCE VT ERROR

SFNSDF = INCDEMENTAI AIJIICTMENT FOR SFNSITIVITY ANALYSIS: FOUALS 7ERO IF

SFNSITIVITY ANAL YSIC NOT HEDUIRFN

SL DPE = EFFECTIVE CHANNEL CLOPF

SLOPEL = SL ONE OF (MANNEL DERIMETER AT LEFT ROUNOARY OF CHANNFL

SLOPFR = SI OPF OF CHANNEL PERTMFTER AT RIGHT ROUNIMARY OF CHANALL

CTAN(INA = STAT[UN NII:AHFR

TIMF. = TINF I)F STAGF AND DISCHANGE MFASUREMFNT

IIMINT = INITIAL TIME

VAPY = VALIARI.E UNDFRGIING, SENSITIVITY ANALYSIS

VEL = COMPUTFI MEAN FLOW VFLOCITY

VELINT = INITIAL STLEAM VFLUCITY

WETPEO = WETTEI) NEDTMFTER

WAVEL = AMSILUTE WAVE VELIICITY

$X=$ HORIZONINI CROSS SECTION COOROINATE

$Y=$ VFRTICAI CROSS SECTION CONDOINATE 


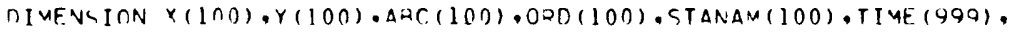
IF (999), DMEA - (994), CPA (1 I0), DPO (100), TVEL (499), VFL (999), DELT (979),

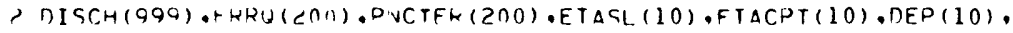

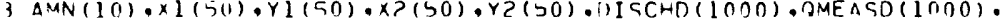
41) $\triangle T E(>0)$

READ (5.5) STANIIM, NOIIEST, NIJMGN, NORUN, AL DHA . SE NGIJF

5 FOHMAT $(4 \mathrm{IH}, 2 \mathrm{CN} \cdot 4)$

READ $(7,7)$ NOTMSP, INXY,ENOVEL, EMARK, (DATE $(N), N=1,10)$

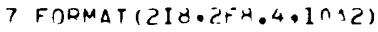

HFAD (G,R) EINT, VELINT, AERTNT, ROELLV, RIVMIL, GRAV,ETA, SL OPE, TIMINT

FTAM $=$ FTA

SLOPEM = SLOUF

$\triangle L P H A M=A L N H A$

Q FORMAT (9FH.11)

KEAD $(5, A)$ WAVEL, VADY, CODE

WAVELM = WAVFL

5 FORMAT (FIO. T. A4,FT.1)

IF (NOUFCT,ES.1) GO TO 44

DO $59 \mathrm{I}=1 \cdot \mathrm{N}: M \mathrm{M}^{-N}$

READ $(5.51)$ IPFD(I) ETASL (I) E T TACPT (I), AMN(I)

51 FORMAT $(4 F 10.4)$

59 CONTINIJF

49 IF (EMARK.F O. '.1)) Gก TO ??

QEAD $(5,55)$ HELEVI, AFLEVZ, AXY 1, IIXYZ

$R E A D(h, 10)(X 1(I), Y I(I), I=1, N X Y I)$

PE $A D(5,10)(\times 2(I), Y \geq(I), I=I, N X Y>)$

55 FORMAT (2Fタ.3.?IS)

(ก) Tि 24

23 PEAD $(5,10)(\times(I), Y(I), I=1, M) \times Y)$

I) FORMAT (1)FQ.1)

24 กO $11 \mathrm{I}=1$, NOTNSP

READ (S.9) TIMF (I), F (I) , DMFAS (I)

9 FORMAT (3F\&. I)

11 CONT INUE

DO $90 \mathrm{I}=2$, NOT $\backsim \mathrm{CP}$

DIJMTM3 $=$ TIMF (I)

DUN1 = NUNTM $3 / 100$.

ПUMTML = $\triangle I N T(1) \cup 01)$

IF (DUMTN4.NE. DUO1) $=0$ TO 02

VFLT (T) $=\Delta B S(T I M F(T)-T I M E(I-1)) \$ 60 .-40.40$.

IF (TI IF (I-1).NF. $240 \cap$.) GO TO 70

DELT (T) = AHS (TIMF. (I) -0000.$) \$ A 0 .-40 . \$ 50$.

Go TO 9 )

प2 DELTI (T) = AMS(TIME (I) - TIMF (I-1))\$60.

G) TONTINIJE

TIME (1) $=$ TIAINT

VEL $(1)=$ VELITIT

DINT =VFI. TNT 4 AF $R$ INT

KOINT = NOTMSP - 1

NRUN $=0$

Y4 THACK $=1.0$

$K D Y=0$

COUNT $=0.0$

IF (CODF.EO.1.0) SLOOE = SLOPEM\#SENSDF

$I F(C O N E . F O \cdot 2 \cdot n)$ WAVFL = WAVELM SENSDF

IF (CONE.EQ.4.11) ALOHA = AI PHAM\#SENSIF 


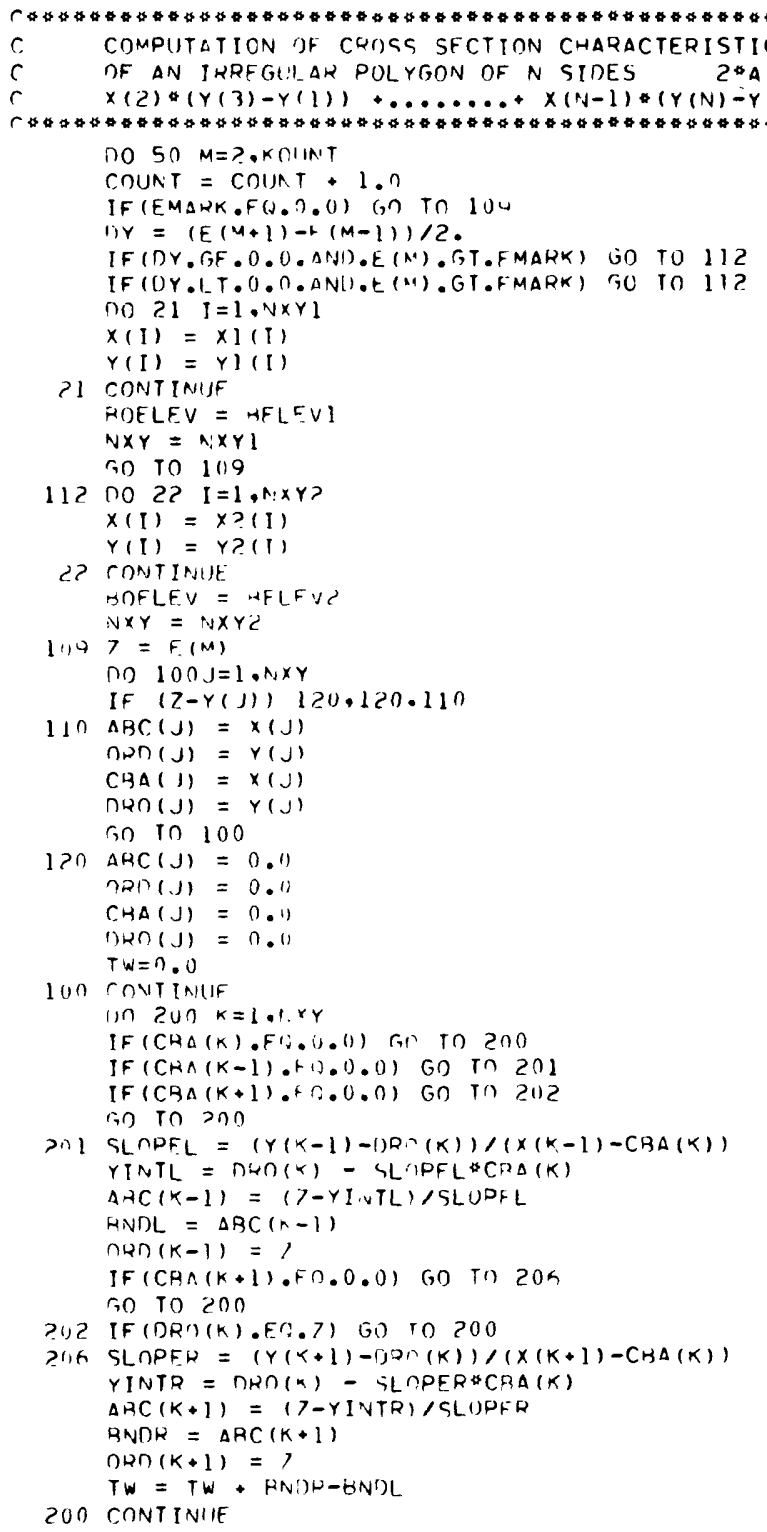

$T W W=A R S(T W)$ 
C, \$4

C. PFARRANGE SIJSCRIPT NUNBFUS OF AHCISSA ANT ONDINATE VAIUES TO PROVIDE

C. FOR SFOUFNTIAI COAPIITATIOH UF 'WETTED JERIMETFR AN', AREA VALUES

C

$r$

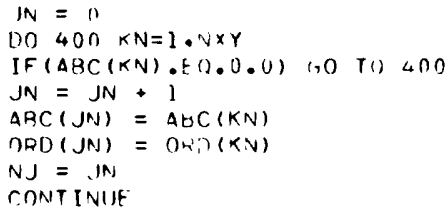

r

400 CONTINUE

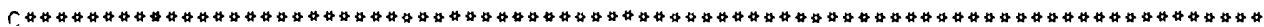

$r$ COMPUTF WETTFD PERT IETER OF CROSS SECTION AT RIVEN STAGE

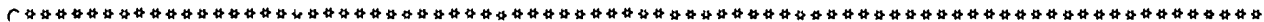

C

WETPER $=0.0$

กO $800 \mathrm{KW}=5, \mathrm{VJ}$

TANA $=(O K D(K W)-O G D(K W-1)) /(\triangle B C(K N)-A B C(K N-1))$

ABTANA = AHS (TANA)

PHI = ATAN (A-3TANA)

$W P=(A B C(K W)-\triangle H C(K W-1)) / C O S(P H I)$

WFTPER = WTPER + WD

QRO CONTINUE

WPP $=$ ARS (WF TPFR)

$r$

C C COMPUTF CROSS SECTIONAL ADFA OF CHANNFL AT GIVEN STAGE

C

r.

$A R E A 1=A B C(1) *(0 R N(2)-O R O(N J))$

$\triangle R E A ?=A B C\left(A_{1} J\right) *(O D \cap(1)-O Q N(N J-1))$

$N N J=N J-1$

SUMARE $=0.0$

DO $500 \mathrm{~J}=\mathrm{S} \cdot \mathrm{N} \cdot \mathrm{NJ}$

SUAARF $=\operatorname{AHC}(J) *(\operatorname{SRN}(J+1)-\operatorname{RQD}(1-1))$

SUMARF = SUNAKF + SIJBARE

50) CONT INUE

DBLARF = ARFAI + ARFAZ + SUMARF

$\triangle R E A=\triangle B S(D H I$ AKE /2.0)

HYDRAI $=A P E A / W P P$

HYIEPT = APEA/TWW

$\cap Y=(E(M+1)-E(M-1)) / 2$.

c

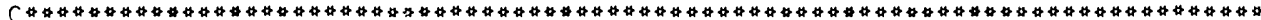
C COMPIJTATION OF MANNTNG'S N USING A LINFAR REI.ATION BETWEEN

C DFPTH AND PUUGHNESS

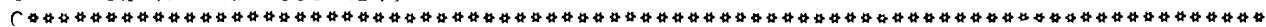

$r$

IF (NQUFST.EQ.1) GO TO 226

กO $69 \mathrm{I}=2$, NLMGN

IF (E (M) . GT.DEP (I-1).ANO.F (M).LE.OEP(I)) GO T: 6B

SO) TO 69

K8 FTA = ETASL $([-1) *(E(M)-B O F L E V)+E T A C P T(I-1)$

(口) TO 227

r.

DY CONTINUE

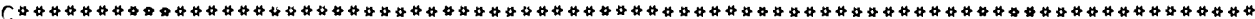
C NFWTON-RAPHSON SOLIITION OF POLYNOMIAL TO IJETEFMINF EXPLICIT VFLOCITY

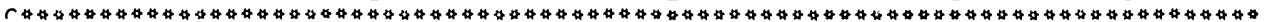
$r$

276 IF (CODE.EQ.3.11) ETA = FTA* \$SENSOF

2:7 $A A=((-\cap Y * A L P H A) /(* A V E L * H Y U E P T))-(((F T A * 2) * G R A V * D E L T(M)) /$

$1(2.22 *(H Y D H \Delta() * 1.3333))$

$B A=((D Y A 1 . P H A) / H Y T E P T-1$.

$C C=$ DELT (M) * GRAV*SLOPE + VEL $(M-1)$ * (UY *GHAV)/WAVEL 
TVEL $(1)=\operatorname{VE} 1,(M-1)$

FDS $=.001$

$M A X=30$

nO $900 \quad N=?, * n x$

PVEL $=$ TVEL $(N-1)$

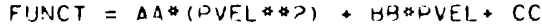

DF.RIV $=2 . \triangle \triangle A D V E L+A H$

TVEL (N) = PVF.I - FUVCT/OEDIV

IF (ARS (TVEL (N)-TVEI. $(N-1))$. LT.F.PS) GO TO 901

900 CONT INUE

Q(i) $\operatorname{VEL}(M)=\triangle B S(T V E L(N))$

(1) $I S C H(M)=V F_{-} I(M) \otimes A E T A$

IF (COUNT.GT.1.1)) IOO TO GAK

WR ITF (6.90?) STANUM

QII FORMAT(IHI, ל? . ISTATION NIMUER =, , IR)

IF(RIVMIL.FD.0.0) in TO 906

WQITF $(6.904)$ \&IVMIL

YI 4 FOPMAT (53X. INIVFH MILF = PFR.)

9I1K WLITE $(6,705)$ W1)ELEV

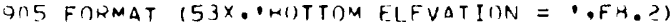

WRITE (n.907) CLUPF.

$91) 7$ FONMAT $(53 \times$. IEFFECTIVF SLMPE $=1 . F R .7)$

WDITE (h, SZ0) $\triangle$ LPHA

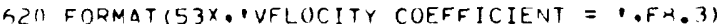

WRITF $(6,640)$ WAVFL

G40 FOPMAT (53X, AMSOLUTF WAVE VELOCITY $=$..FH.3)

WHITF. $(5.610)$ ENUVEL

610 FORMAT (53X. .FINAL VFLOCITY = ..F8.?)

IF (NDIJECT.NF. I) GO TO 779

WPITE $(6.775)+T A$

775 FORMAT $(53 x$.' MANNINGC $N=1.75 .4)$

778 WHITE $(4,908)$ (1)ATE (N), N $=1,1 \cap$ )

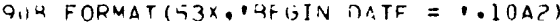

IF (NOIIFST.F.C. I) GO TO 719

WITT $(6.569)$

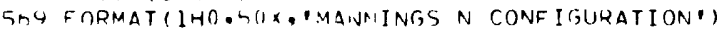

WDITF $(6.57 H)$

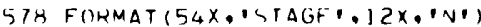

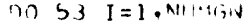

WDITE $(6.579)$ 'EEP(I) . AMN (I)

S/9 FORMAT (51X,F111.2.2X.F10.5)

53 CONTINUTF

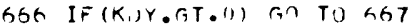

770 NTTE (K,

WRI TF $(6,35 ?)$

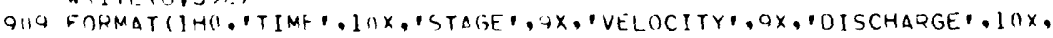

1 'DISCHADGE')

WRITE $(5,910)$

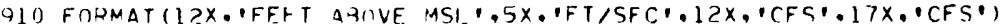
WRITE $(0.911)$

911 FORMAT (46X. 'COMPIITFO', $10 \times$. MMEASURED')

IF (TRACK.GT.1.0) GO TO 667

WHITE (6.912) TIMINT, FINT, VELINT, IINT

91? FORMAT(FG. ח.10X,Fn.?.10X,F5.2,27X,F7.2)

607 IF (QMFAS(N) .1,T.0.0) GO TO 777

WRITE $(G \cdot S>0)$ TIMF (M),F (M), VEL (M) D DISC $-1(Y)$

$5>0$ FORMAT (F6.0,10X.FG.?.10X.F5.2,10X,FR.?)

(-1) $T \cap 7 \cap 1$

777 WUITF $(6,51 \cap)$ TIME (M), E (M) , VEL (M) , OISCH(M) , VMEAS $(M)$

510 FOHMAT (FG.0,10X.FG.?.10X,F5.2,10X,FR.?,10X,FH.2)

$701 \mathrm{KDY}=\mathrm{KDY}+1$

DISCHO (KDY) $=01 S C H(M)$

NMFASก $(K D Y)=$ OME $\triangle S(M)$

IF (TIMF (M) .LF.TIMF $(v+1))$ rOก TO 50) 
SUMERT $=0.0$

SUMD? $=0.0$

SMPNTF $=0.1$

SUMOI $=0.0$

(1)TRACK $=0.0$

1) $411 \mathrm{~J}=2 \cdot K_{1} \cdot Y$

SUMOZ = SLMOP + OISTHD(J)

IF (OMFASD (J).FQ.0.ก) GO TO 411

SUMOI = SLMOI + DMF $\triangle S D(J)$

OTRACK = DTRACK + 1.0

$\left.\operatorname{ERR(A)}(J)=\operatorname{AHS}\left(2 M+A S_{1}\right)(J)-1\right) \operatorname{ISC}(4)(J)$

SUMERO = SUMFQO + FPRA (J)

PNCTER(J) = (FPRI) (.J)/OMEACD (J)) $\$ 100$.

SMPNTF = SMRNTE + PAICTER ( J)

411 CONTINIJF

$\triangle V G O C=\operatorname{SUM}(T) / K U Y$

IF (BTRACK.FQ.1).0) rin TO 30 ?

$A V G O M=$ SUMGLINTHACK

AVGER = SUMF ROJOTRACK

$\triangle V G P N T=$ SMPVTF/ATRRACK

1) $(F S)=0.0$

1) IFSOL $=0.0$

in $\left.421 \mathrm{~J}=2, k_{1}\right) Y$

IF (OMEASD (J) .F..0.ก) GO TO 421

1) $1 F S O 1=(F K R(J)-A \cup G E N) * 2+n I F S O I$

DIFSD = (ONCTER(J) - AVISPUT) ? + DIFSO

421 CONTINIJE

NMSI = SORT (1)IFS SNI/OTPACK)

RMS = SORT (I)IF SO/NTRACK)

Oก 3 WRITE $(6,39 ?)$

उपर FORMAT $(1 H O)$

WRITE $(6,441) \quad \triangle V G Q C$

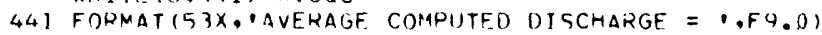

IF (QTRACK.EQ.).0) is TO 7 त

WRITF $(5,431)$ AVGUM

431 FORNAT $(53 X$. . AVËHAGF MFASULEU DISCHARGF $=1, F Q .0)$

WQITF. $(K, 471)$ AVGEN

471 FORMAT (53X, 'AVEKAGF COMPUTATIONAL ERROK = . F9.?) WRITF $(5,397)$

WHITF (K.4לL) AVGPNT

4 SI FORMAT (53.. . AVEHAI,E COMPUTATION FRROR IN PFRCFNT $=$, F7.2) WHITE (5.4MI) P.151

4MI FORMAT (5.3X. ISTANUARI DFVIATION OF COMNUTATIONAL ERROR = . .F9.2I WPITE $(6,461)$ HMS

4H I FOHMAT(53X, ICTANIJALT DEVIATION OF PERCENT ERPOR = ..F7.? )

7nY Ki)Y $=0$

TPACK = THACK + 1

WQITF $(A, 3 \rightarrow 3)$

3U3 FOLMAT (IHI)

WRITH $(6.565)$ T2ACK

565 FORNAT $(50 X, 114 Y \cdot, F 4.0)$

SO) CONTINUF

IF (SENSOF.FW.0.0) SO TO 9 SY

SENFAC $=$ SENSUF $\$ 100$.

WRITF (K. K70) VARY

670 FORMAT $(53 \mathrm{X}$, , VALIAHLF UNDEKGOING SENSITIVITY ARALYSIS = , A4) WDITE (6.699) CFNFAC.

699 FORMAT $53 \times$. OVALUF OF SENSITIVITY FACTUN, [N PERCENT $=1,57.3$ ] IF (NOPUN.EO.(1) GO Th 969 IF (NRIJN.FQ.NITIIN) RT) TO QRY

NOIJN = NRIIN + I

SENSTJF = SENSITF + .

in TO 99

URY STOP

Fivi) 
Such statistics indicate that average station discharge and average stream velocity for a particular dynamic flow event can be accurately computed using the method described in this paper.

The accuracy of computed instantaneous dynamic discharges is indicated in tables 8 and 9 as well as on figures 13 to 16 . Measured and computed rise and recession discharges at water-surface altitudes representing $10,25,50,75$, and 90 percent of total stage change are compared at Littles Ferry Bridge (table 8) and at Georgia Highway 141 (table 9). With the exception of two discharges computed at Littles Ferry Bridge the error between measured and computed instantaneous discharge is less than 15 percent for every stage value at both stations.

An interesting comparison can be made between rated and computed discharges at Georgia Highway 141. Measured, computed, and rating-curve values of instantaneous station discharge at various stages are listed in table 9 . Use of the rating curve to estimate discharge on the rising limb of the hydrograph is shown to be unsatisfactory with errors ranging from 17 to 25 percent. Errors for corresponding computed discharges, on the other hand, ranged from 4 to 14 percent. Both computed and rating-curve estimates of recession discharge at Georgia Highway 141 are shown to be satisfactory.

The data presented in figures 13 to 16 and in tables 8 and 9 indicate that the mathematical model presented in this paper can, with few exceptions, compute highly dynamic discharge within acceptable limits of error. In particular the model extends the utility of gaging station records; computing mean daily and instantaneous dynamic discharges with far greater accuracy than could otherwise be obtained from single value rating curves. In addition, data utilized in the computation scheme are, for the most part, routinely collected during station operation.

\section{SENSITIVITY ANALYSES}

The sensitivity of highly dynamic discharge to various flow and channel parameters was determined by using the model computations in conjunction with adjusted values of selected parameters. Parameters investigated include Manning's $n$, effective channel slope $\left(S_{o}\right)$, absolute wave velocity $\left(V_{w}\right)$, and the velocity coefficient $(\alpha)$. Flow data used in the sensitivity analyses were those collected on March 23, 1976 at Georgia Highway 120. For each analysis, the parameter being investigated was varied from 10 to 200 percent of its observed value while other model parameters remained at observed values. Model sensitivity is illustrated in figure 21 where values of mean computation error in percent are 
TABLE 8.-Measured and computed discharges at Littles Ferry Bridge, 0850 to 2120 hours-March 23, 1976

\begin{tabular}{cccccccc}
\hline \multirow{2}{*}{$\begin{array}{c}\text { Total stage } \\
\text { change } \\
\text { percent }\end{array}$} & $\begin{array}{c}\text { Measured } \\
\text { discharge } \\
\left(\mathrm{ft}^{3} / \mathrm{s}\right)\end{array}$ & $\begin{array}{c}\text { Computed } \\
\text { discharge } \\
\left(\mathrm{ft}^{3} / \mathrm{s}\right)\end{array}$ & $\begin{array}{c}\text { Error } \\
\text { percent }\end{array}$ & & $\begin{array}{c}\text { Measured } \\
\text { discharge } \\
\left(\mathrm{ft}^{3} / \mathrm{s}\right)\end{array}$ & $\begin{array}{c}\text { Recession } \\
\text { dischuted } \\
\left(\mathrm{ft}^{3} / \mathrm{s}\right)\end{array}$ & $\begin{array}{c}\text { Error } \\
\text { percent }\end{array}$ \\
\hline $\mathbf{1 0}$ & 1,950 & 1,350 & 31 & & 5,370 & 5,670 & 5.6 \\
$\mathbf{2 5}$ & $\mathbf{2 , 7 0 0}$ & $\mathbf{2 , 1 3 0}$ & 21 & & $\mathbf{4 , 1 6 0}$ & 4,060 & 2.4 \\
$\mathbf{5 0}$ & 4,380 & 3,770 & 14 & & 2,800 & 3,020 & 7.9 \\
$\mathbf{7 5}$ & 5,890 & 5,650 & 4.1 & & 1,860 & 1,830 & 1.6 \\
$\mathbf{9 0}$ & 7,220 & 6,780 & 6.1 & 1,330 & 1,330 & 0.0 \\
\hline
\end{tabular}

TABLE 9.-Measured, computed, and rating-curve discharges at Georgia Highway 141-1105 to 2310 hours-March 23, 1976

\begin{tabular}{|c|c|c|c|c|c|}
\hline \multirow{3}{*}{$\begin{array}{l}\text { Total stage } \\
\text { change } \\
\text { percent }\end{array}$} & \multicolumn{5}{|c|}{ Rise } \\
\hline & \multirow[t]{2}{*}{$\begin{array}{c}\text { Measured } \\
\text { dischargee } \\
\left(\mathrm{ft}^{3} / \mathrm{s}\right)\end{array}$} & \multirow[t]{2}{*}{$\begin{array}{c}\text { Computed } \\
\text { discharge } \\
\left(\mathrm{ft}^{3} / \mathrm{s}\right)\end{array}$} & \multirow[t]{2}{*}{$\begin{array}{c}\text { Rated } \\
\text { discharge } \\
\left(\mathrm{ft}^{3} / \mathrm{s}\right)\end{array}$} & \multicolumn{2}{|c|}{$\begin{array}{c}\text { Error } \\
\text { percent }\end{array}$} \\
\hline & & & & Equation (12) & Rating curve \\
\hline 10 & 2,060 & 1,780 & 1,580 & 14.0 & 23 \\
\hline 25 & 2,890 & 2,500 & 2,160 & 14.0 & 25 \\
\hline 50 & 4,080 & 3,920 & 3,270 & 3.9 & 20 \\
\hline 75 & 5,610 & 5,260 & 4,490 & 6.2 & 20 \\
\hline \multirow[t]{2}{*}{90} & 6,410 & 6,000 & 5,290 & 6.3 & 17 \\
\hline & \multicolumn{5}{|c|}{ Recession } \\
\hline \multirow[t]{2}{*}{$\begin{array}{l}\text { Total stage } \\
\text { change } \\
\text { percent }\end{array}$} & $\begin{array}{c}\text { Measured } \\
\text { discharge } \\
\left(\mathrm{ft}^{3} / \mathrm{s}\right)\end{array}$ & $\begin{array}{c}\text { Computed } \\
\text { discharge } \\
\left(\mathrm{ft}^{3} / \mathrm{s}\right)\end{array}$ & $\begin{array}{c}\text { Rated } \\
\text { discharge } \\
\left(\mathrm{ft}^{3} / \mathrm{s}\right)\end{array}$ & \multicolumn{2}{|c|}{$\begin{array}{c}\text { Error } \\
\text { percent }\end{array}$} \\
\hline & & & & Equation (12) & Rating curve \\
\hline 10 & 5,620 & 5,340 & 5,400 & 5.0 & 3.9 \\
\hline 25 & 4,870 & 4,620 & 4,760 & 5.1 & 2.3 \\
\hline 50 & 3,720 & 3,620 & 3,780 & 2.7 & 1.6 \\
\hline 75 & 2,740 & 2,690 & 2,860 & 1.8 & 4.4 \\
\hline 90 & 2,360 & 2,190 & 2,330 & 7.2 & 1.3 \\
\hline
\end{tabular}

plotted against the percent of observed value of the given parameter.

Model results were most sensitive to changes in Manning's $n$ and least sensitive to changes in velocity coefficient. Sensitivity to changes in effective channel slope and sensitivity to low percentage values of absolute wave velocity was also noted. Model computations were much more sensitive to gross underestimates of parameter values than to corresponding overestimates.

\section{OTHER COMPARISONS}

On November 15, 1956, the U.S. Army Corps of Engineers made a series of 7 discharge measurements at Georgia Highway 20 in 


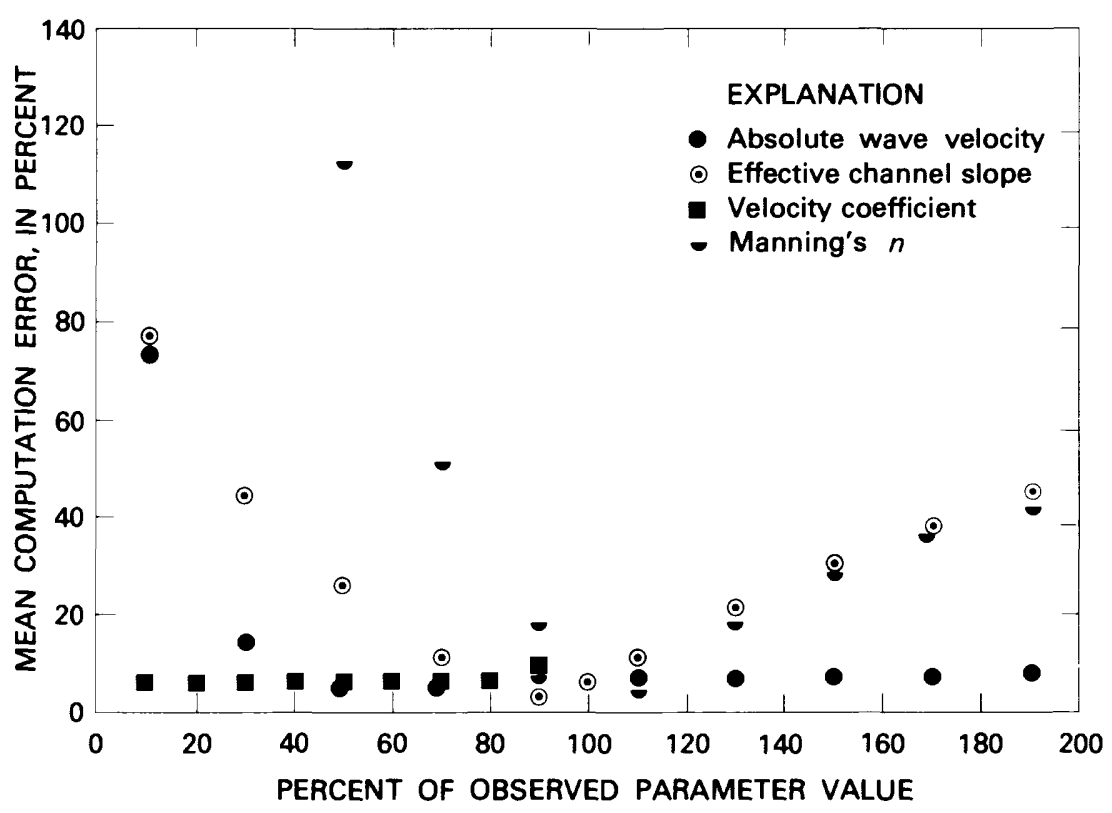

Figure 21.-Sensitivity of highly dynamic discharge to channel and flow parameters.

conjunction with a power generation cycle at Buford Dam. In order to apply those measurements to the mathematical model described in this report the effective channel slope and wave velocity observed at Georgia Highway 20 in March 1976 were assumed to have remained unchanged with time. However, observed streambank erosion and bottom scour have significantly changed channel roughness and geometry along the study reach since 1956. Thus, required cross-section coordinates and Manning's $n$ values were computed, using data from the 1956 discharge notes. Computed Manning's $n$ was nearly constant at 0.031 , based on one high and two low-flow measurements. Continuous stage data were also obtained from the discharge notes and from linear interpolation between direct measurements. The results of applying the 1956 measurements to the mathematical model are shown in figure 22. Where data are available for comparison, computed and measured discharges are nearly coincident (fig. 22).

Jobson and Keefer (1979) used an implicit, finite difference, flow-routing model, in conjunction with the flow and channel geometry data listed in this report (tables 10 to 13), to compute the four hysteretic, stage-discharge relations described previously (figs. 13 to 16). Comparison of the relations computed with the 


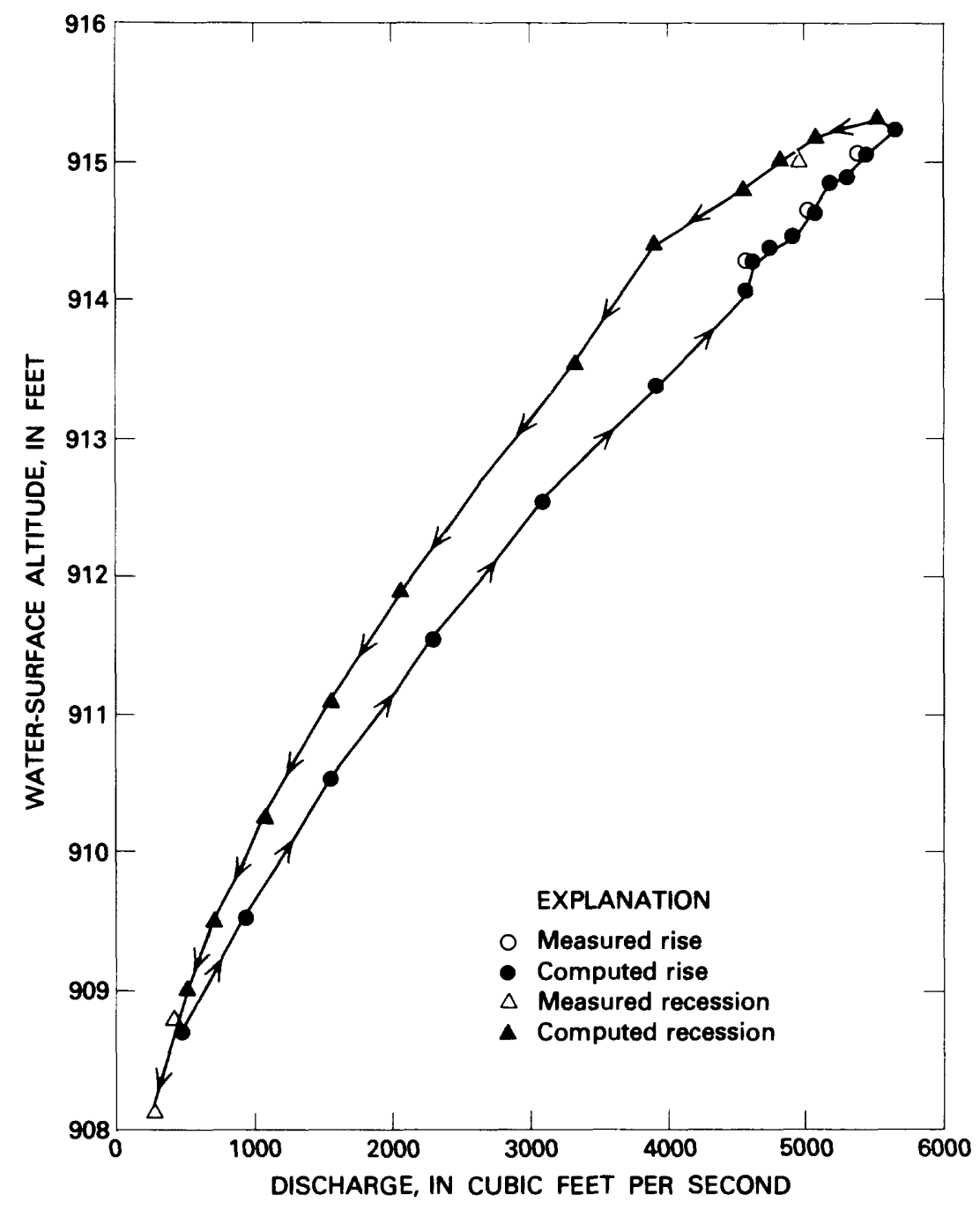

FIGURE 22.-Computed hysteretic stage-discharge relation at Georgia Highway 20-0732 to 1733 hours-November $15,1956$.

flow-routing model to those computed by the model described in this paper indicates that the flow-routing model tended to underestimate peak discharges and exaggerate hysteresis at intermediate stages. 


\section{CONCLUSIONS}

The mathematical model presented in this paper and the model presented by Fread (1975) indicate that the equations describing one-dimensional, unsteady flow in open channels can mathematically describe, with reasonable accuracy, highly dynamic flow at a stream station. Fread's model was applied to large rivers where rates of stage rise were about $1 \mathrm{ft} /$ day and channel slopes are on the order of $10^{-5} \mathrm{ft} / \mathrm{ft}$. Comparison of observed discharges with those computed by Fread (1975) provided root mean square errors of 7 percent or less. The similar but more general model presented in this paper was applied to a short reach of the Chattahoochee River in northeast Georgia. Top widths in this reach range from about 150 to 300 feet and channel slopes are on the order of $10^{-4} \mathrm{ft} / \mathrm{ft}$. Observed rates of stage change were in excess of $5 \mathrm{ft} / \mathrm{hr}$. Simulation of hysteretic stage-discharge relations at four stations provided average computation errors of 9 percent or less.

Thus the same general methodology, applied to both large and small rivers as well as to relatively "sluggish" to highly dynamic flow conditions, mathematically computed unsteady discharge with a high degree of accuracy. Mathematical models which apply this methodology are particularly useful at gaging stations where stage records of dynamic flow are to be converted to instantaneous or mean daily discharges.

Data used to test the model presented in this paper are part of a detailed, comprehensive base of flow and channel data collected for an earlier study. These data are discussed and listed in this paper and can be used to test the computational accuracy of flowrouting or other models that simulate highly dynamic, openchannel flow. 


\section{SELECTED REFERENCES}

Buchanan. T. J., and Somers, W. P., 1969, Discharge measurements at gaging stations, chap. A8 of bk. 3, Applications of hydraulics: U.S. Geological Survey, Techniques of Water-Resources Investigations, $65 \mathrm{p}$.

Cherry, R. N., Faye. R. E., Stamer, J. K., and McGinty, H. D., 1976, Plan for river quality assessment, Upper Chattahoochee River basin, Georgia: American Water Works Association, River Water Quality Assessment Seminar, Proceedings, no. 20133.

Chow, V. T., 1959, Open channel hydraulics: New York, McGraw-Hill, 680 p.

Fread, D. L., 1975, Computation of stage-discharge relationships affected by unsteady flow: Water Resources Bulletin, v. 11, no. 2, p. 213-228.

Georgia Department of Natural Resources, 1976, Geologic Map of Georgia.

Jobson, H. E., and Keefer, T. N., 1979, Modeling of highly transient flows, mass, and heat transfer in the Chattahoochee River near Atlanta, Georgia: U.S. Geological Survey Open File Report, 79-270, 139 p.

Kibler, D. F. and Woolhiser, D. A., 1970, The kinematic cascade as a hydrologic model: Colorado State University, Fort Collins, Hydrology Paper 39, $27 \mathrm{p}$.

Lighthill, M. J., and Whitham, G. B., 1955, On kinematic waves I, Flood movements in long rivers: Royal Soc. [London] Proc., A229, p. 281-316.

Linsley, R. K., Kohler, M. A., and Paulhus, J. L., 1975, Hydrology for Engineers (2d ed.) : New York, McGraw-Hill, $482 \mathrm{p}$.

U.S. Army Corps of Engineers, 1973, Flood plain information-Chattahoochee River, Buford Dam to Whitesburg, Georgia: Mobile District, Alabama, 16 p., 50 plates.

Yevdjevich, V. M., 1964, Bibliography and discussion of flood-routing methods and unsteady flow in channels: U.S. Geological Survey Water-Supply Paper 1690, 235 p. 
TABLE 10.-Summary of river stage data

\begin{tabular}{|c|c|c|c|c|c|}
\hline \multirow[b]{2}{*}{$\begin{array}{c}\text { Date and } \\
\text { Time }\end{array}$} & \multicolumn{5}{|c|}{ Water-surface altitude, in feet } \\
\hline & $\begin{array}{c}\text { Buford } \\
\text { Dam }\end{array}$ & $\begin{array}{c}\text { Georgia } \\
\text { Highway } 20\end{array}$ & $\begin{array}{c}\text { Littles } \\
\text { Ferry } \\
\text { Bridge }\end{array}$ & $\begin{array}{c}\text { Georgia } \\
\text { Highway } 120\end{array}$ & $\begin{array}{c}\text { Georgia } \\
\text { Highway } 14\end{array}$ \\
\hline \multicolumn{6}{|l|}{ March 21, 1976: } \\
\hline 0000 & 913.38 & 903.03 & & --.-- & 880.37 \\
\hline 0005 & 913.38 & 903.03 & $\ldots$ & ... & -...- \\
\hline 0010 & 913.38 & 903.03 & $-\ldots$ & $-1-$ & $-\ldots$ \\
\hline 0015 & 913.38 & 903.03 & $\ldots$ & -...- & $\ldots$ \\
\hline 0020 & 913.38 & 903.03 & $-\ldots$ & $-\overline{--1}$ & $-\ldots$ \\
\hline 0025 & 913.38 & 903.03 & 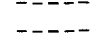 & 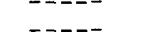 & \\
\hline 0030 & 913.38 & 903.03 & 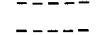 & $-\ldots$ & 880.36 \\
\hline 0035 & 913.38 & 903.03 & & -n- & ..... \\
\hline 0040 & 913.38 & 903.03 & $-\ldots$ & $-\cdots$ & - \\
\hline 0045 & 913.38 & 903.03 & & $-\ldots$ & $\ldots$ \\
\hline 0050 & 913.38 & 903.03 & $-\cdots$ & $-\cdots$ & $-\ldots-1$ \\
\hline 0055 & 913.38 & 903.03 & $-\ldots$ & $-\ldots$ & $-\ldots$ \\
\hline 0100 & 913.38 & 903.03 & $\ldots$ & $\ldots$ & $\ldots$ \\
\hline 0105 & 913.38 & 903.03 & & $\ldots$ & $-\ldots$ \\
\hline 0110 & 913.38 & 903.03 & $-\ldots$ & $-\ldots$ & $-\ldots$ \\
\hline 0115 & 913.38 & 903.03 & & $\ldots$ & $-\ldots$ \\
\hline 0120 & 913.38 & 903.03 & 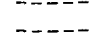 & $\ldots$ & -1 \\
\hline 0125 & 913.38 & 903.03 & & & \\
\hline 0130 & 913.38 & 903.03 & - n & 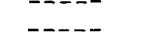 & 880.35 \\
\hline 0135 & 913.38 & 903.03 & & & $\ldots$ \\
\hline 0140 & 913.38 & 903.03 & $-\cdots$ & -1 & $\ldots$ \\
\hline 0145 & 913.38 & 903.03 & & $\ldots$ & \\
\hline 0150 & 913.38 & 903.03 & $\ldots$ & $\ldots$ & -1 \\
\hline 0155 & 913.38 & 903.03 & & & $\ldots$ \\
\hline 0200 & 913.38 & 903.03 & 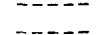 & $-\cdots$ & $-\cdots$ \\
\hline 0205 & 913.38 & 903.03 & & - & $-\ldots$ \\
\hline 0210 & 913.38 & 903.03 & $\ldots$ & $\ldots$ & $\ldots$ \\
\hline 0215 & 913.38 & 903.04 & & $\ldots$ & -- \\
\hline 0220 & 913.38 & 903.04 & $\cdots$ & $\cdots$ & $-\cdots$ \\
\hline 0225 & 913.38 & 903.04 & & & \\
\hline 0230 & 913.38 & 903.04 & $\cdots$ & $-\cdots$ & $8 \overline{80.35}$ \\
\hline 0235 & 913.38 & 903.04 & & & \\
\hline 0240 & 913.38 & 903.04 & $-\ldots$ & $\ldots$ & $-\cdots$ \\
\hline 0245 & 913.38 & 903.04 & & - & $-\ldots$ \\
\hline 0250 & 913.38 & 903.04 & $\cdots$ & 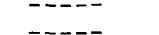 & $-\cdots$ \\
\hline 0255 & 913.38 & 903.05 & & - n- & $-\cdots$ \\
\hline 0300 & 913.38 & 903.05 & -1 & $-\cdots$ & $\cdots$ \\
\hline 0305 & 913.38 & 903.05 & & -n. & 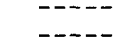 \\
\hline 0310 & 913.38 & 903.05 & $-\cdots$ & & $-\cdots$ \\
\hline 0315 & 913.38 & 903.05 & $\cdots-$ & $\cdots$ & $\cdots-$ \\
\hline 0320 & 913.38 & 903.05 & -1 & -1 & $\ldots$ \\
\hline 0325 & 913.38 & 903.05 & $-\cdots$ & $\cdots$ & $\cdots$ \\
\hline 0330 & 913.38 & 903.06 & $\ldots$ & $\ldots$ & 880.36 \\
\hline 0335 & 913.38 & 903.06 & & - & \\
\hline 0340 & 913.38 & 903.06 & -- & $\ldots$ & $-1-1$ \\
\hline 0345 & 913.38 & 903.06 & & $-\cdots$ & 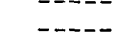 \\
\hline 0350 & 913.38 & 903.07 & $\ldots$ & $\ldots$ & 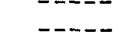 \\
\hline 0355 & 913.38 & 903.07 & & ---1 & -1 \\
\hline 0400 & 913.38 & 903.07 & $\ldots$ & $-\cdots$ & $-\cdots$ \\
\hline 0405 & 913.38 & 903.07 & $\ldots .$. & - & - n-..- \\
\hline 0410 & 913.38 & 903.07 & $\ldots$ & - & $-\cdots$ \\
\hline 0415 & 913.38 & 903.08 & $\ldots$ & $\ldots$ & $\ldots$ \\
\hline 0420 & 913.38 & 903.08 & $\ldots$ & $\ldots$ & $-\cdots$ \\
\hline 0425 & 913.38 & 903.09 & -1 & & -1 \\
\hline 0430 & 913.38 & 903.09 & -...- & $\ldots$ & 880.40 \\
\hline 0435 & 913.38 & 903.09 & -..-- & -...- & .... \\
\hline 0440 & 913.38 & 903.10 & $\ldots$ & $\ldots$ & -...- \\
\hline
\end{tabular}


TABLE 10.-Summary of river stage data-Continued

\begin{tabular}{|c|c|c|c|c|c|}
\hline \multirow[b]{2}{*}{$\begin{array}{l}\text { Date and } \\
\text { Time }\end{array}$} & \multicolumn{5}{|c|}{ Water-surface altitude, in feet } \\
\hline & $\begin{array}{c}\text { Buford } \\
\text { Dam }\end{array}$ & $\begin{array}{c}\text { Georgia } \\
\text { Highway } 20\end{array}$ & $\begin{array}{l}\text { Littles } \\
\text { Ferry } \\
\text { Bridge }\end{array}$ & $\begin{array}{c}\text { Georgia } \\
\text { Highway } 120\end{array}$ & $\begin{array}{c}\text { Georgia } \\
\text { Highway } 141\end{array}$ \\
\hline \multicolumn{6}{|l|}{ March 21, 1976: } \\
\hline 0445 & 913.38 & 903.10 & ----- & ----- & - - - \\
\hline 0450 & 913.38 & 903.11 & ---- & ---- & 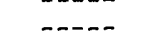 \\
\hline 0455 & 913.38 & 903.11 & ----- & ---- & $\begin{array}{ll}-2-n \\
-n-2\end{array}$ \\
\hline 0500 & 913.38 & 903.11 & ----- & - n- & $\begin{array}{ll}--n-2 \\
--n-2\end{array}$ \\
\hline 0505 & 913.38 & 903.11 & --n-- & --- & --n- \\
\hline 0510 & 913.38 & 903.11 & 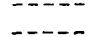 & -n- & 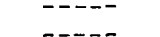 \\
\hline 0515 & 913.38 & 903.12 & 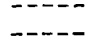 & $\begin{array}{ll}--n-1 \\
-n-n\end{array}$ & $\begin{array}{ll}--n-2 \\
--n-n\end{array}$ \\
\hline 0520 & 913.38 & 903.12 & ----- & 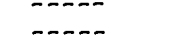 & $--2--$ \\
\hline 0525 & 913.38 & 903.12 & -n- & $\begin{array}{ll}n-2 \\
-n-2\end{array}$ & 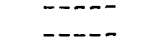 \\
\hline 0530 & 913.38 & 903.13 & 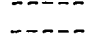 & $\begin{array}{l}---n- \\
--n-\end{array}$ & $880.4 \overline{4}$ \\
\hline 0535 & 913.38 & 903.13 & - - - - & - & ..... \\
\hline 0540 & 913.38 & 903.13 & ----- & - - - - & - - - - \\
\hline 0545 & 913.38 & 903.14 & 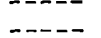 & - & 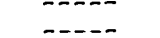 \\
\hline 0550 & 913.38 & 903.14 & $\begin{array}{l}---1 \\
--1-\end{array}$ & 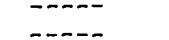 & 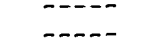 \\
\hline 0555 & 913.38 & 903.14 & $\begin{array}{l}----1 \\
-\cdots-2\end{array}$ & $\begin{array}{ll}-\cdots-1 \\
-\cdots-1\end{array}$ & -n- \\
\hline 0600 & 913.38 & 903.14 & $\begin{array}{ll}--2-2 \\
--2\end{array}$ & $\begin{array}{l}----- \\
-----\end{array}$ & 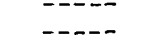 \\
\hline 0605 & 913.38 & 903.14 & $\begin{array}{l}---- \\
--n-\end{array}$ & $\begin{array}{l}----- \\
-----\end{array}$ & 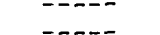 \\
\hline 0610 & 913.38 & 903.15 & $m-n$ & 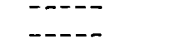 & -an- \\
\hline 0615 & 913.38 & 903.15 & -n- & $\begin{array}{l}----- \\
-----\end{array}$ & ----- \\
\hline 0620 & 913.38 & 903.16 & $\begin{array}{ll}--n- \\
--n-\end{array}$ & -n-- & ---- \\
\hline 0625 & 913.38 & 903.16 & ---- & ---- & ----0 \\
\hline 0630 & 913.38 & 903.16 & ---- & 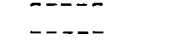 & $\overline{880.5 \overline{2}}$ \\
\hline 0635 & 913.38 & 903.16 & ---- & $\begin{array}{l}---1-- \\
-\ldots-1\end{array}$ & - \\
\hline 0640 & 913.38 & 903.17 & ----- & - $-1-1$ & $\begin{array}{l}----- \\
--\cdots-\end{array}$ \\
\hline 0645 & 913.38 & 903.17 & - & --n- & 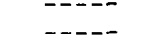 \\
\hline 0650 & 913.38 & 903.18 & ---- & 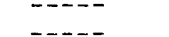 & ---- \\
\hline 0655 & 913.38 & 903.19 & ---- & 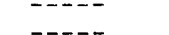 & ----- \\
\hline 0700 & 913.38 & 903.19 & $----n$ & ---- & ---- \\
\hline 0705 & 913.38 & 903.20 & $-\cdots$ & ---- & ----- \\
\hline 0710 & 913.38 & 903.21 & $\begin{array}{ll}--n-1 \\
-1-n\end{array}$ & $-1-1$ & $--\cdots$ \\
\hline 0715 & 913.38 & 903.21 & ----- & & ----- \\
\hline 0720 & 913.38 & 903.22 & 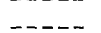 & & $-\cdots--$ \\
\hline 0725 & 913.38 & 903.22 & 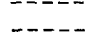 & $\begin{array}{l}---- \\
--\cdots-\end{array}$ & $-\cdots-$ \\
\hline 0730 & 913.38 & 903.23 & ---- & - - - & $\overline{880} \overline{58}$ \\
\hline 0735 & 913.38 & 903.24 & ----- & $\begin{array}{l}----- \\
-----\end{array}$ & - \\
\hline 0740 & 913.38 & 903.25 & $\begin{array}{l}----- \\
--n--\end{array}$ & 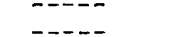 & $--n--$ \\
\hline 0745 & 913.38 & 903.25 & $\begin{array}{ll}--n-1 \\
\cdots-n\end{array}$ & 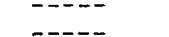 & ----0 \\
\hline 0750 & 913.38 & 903.26 & $m-$ & $\begin{array}{l}-----1 \\
--0-\end{array}$ & 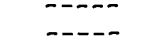 \\
\hline 0755 & 913.38 & 903.26 & -n-- & 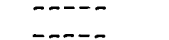 & ---- \\
\hline 0800 & 913.38 & 903.26 & 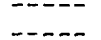 & $-\cdots--$ & ----- \\
\hline 0805 & 913.38 & 903.27 & -n- & $\overline{-n-1}$ & $-\cdots--$ \\
\hline 0810 & 913.38 & 903.27 & ----- & 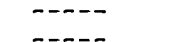 & ----- \\
\hline 0815 & 913.38 & 903.28 & $-\ldots$ & -ne- & $-\cdots--$ \\
\hline 0820 & 913.38 & 903.28 & --- & $-\cdots-$ & $-\cdots--$ \\
\hline 0825 & 913.38 & 903.28 & 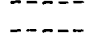 & $-\cdots-$ & $-\cdots$ \\
\hline 0830 & 913.38 & 903.28 & 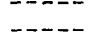 & $-\cdots--$ & $00-\overline{5}$ \\
\hline 0835 & 913.38 & 903.29 & $--0-$ & ----- & 880.65 \\
\hline 0840 & 913.38 & 903.29 & $-\cdots--$ & ---- & ----- \\
\hline 0845 & 913.38 & 903.30 & $\cdots-\cdots$ & ----- & ----- \\
\hline 0850 & 913.38 & 903.28 & $-\cdots--$ & ----- & ---- \\
\hline 0855 & 913.38 & 903.29 & $-\cdots-\cdots$ & $-\cdots--$ & ---- \\
\hline 0900 & 913.38 & 903.29 & ---- & ---- & $\ldots-\cdots$ \\
\hline 0905 & 913.38 & $\begin{array}{l}903.29 \\
903.28\end{array}$ & $-\cdots-$ & ----- & ---- \\
\hline 0910 & $\begin{array}{l}913.00 \\
913.38\end{array}$ & $\begin{array}{l}903.28 \\
903.29\end{array}$ & $\ldots-$ & ---- & $-\cdots--$ \\
\hline 0910 & & 903.29 & $----n$ & ---- & $--n-$ \\
\hline 0910 & $\begin{array}{l}913.38 \\
913.38\end{array}$ & 903.28 & $\ldots--$ & ---- & ---- \\
\hline 0920 & $\begin{array}{l}913.38 \\
913.38\end{array}$ & 903.29 & $-\cdots--$ & ---- & $---n$ \\
\hline 0925 & 913.38 & 903.29 & $---n$ & $----n$ & 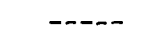 \\
\hline
\end{tabular}


TABLE 10.-Summary of river stage data-Continued

\begin{tabular}{|c|c|c|c|c|c|}
\hline \multirow[b]{2}{*}{$\begin{array}{l}\text { Date and } \\
\text { Time }\end{array}$} & \multicolumn{5}{|c|}{ Water-surface altitude, in feet } \\
\hline & $\begin{array}{c}\text { Buford } \\
\text { Dam }\end{array}$ & $\begin{array}{c}\text { Georgia } \\
\text { Highway } 20\end{array}$ & $\begin{array}{l}\text { Littles } \\
\text { Ferry } \\
\text { Bridge }\end{array}$ & $\begin{array}{c}\text { Georgia } \\
\text { Highway } 120\end{array}$ & $\begin{array}{c}\text { Georgia } \\
\text { Highway } 141\end{array}$ \\
\hline \multicolumn{6}{|l|}{ March 21, 1976: } \\
\hline 0930 & 913.38 & 903.28 & ----- & - & 880.70 \\
\hline 0935 & 913.38 & 903.29 & $---n$ & ---- & - - - \\
\hline 0940 & 913.38 & 903.28 & $\begin{array}{ll}----- \\
--n\end{array}$ & $\begin{array}{ll}---n \\
-n---\end{array}$ & - n- \\
\hline 0945 & 913.38 & 903.28 & ---- & 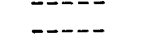 & - n \\
\hline 0950 & 913.38 & 903.27 & $---n$ & $---n$ & 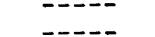 \\
\hline 0955 & 913.38 & 903.27 & 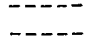 & $\begin{array}{ll}---- \\
----\end{array}$ & \\
\hline 1000 & 913.38 & 903.27 & ---- & $\begin{array}{ll}----- \\
--n--\end{array}$ & 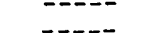 \\
\hline 1005 & 913.38 & 903.26 & ---- & ---- & $----\infty$ \\
\hline 1010 & 913.38 & 903.26 & $---\infty$ & ----- & ---0 \\
\hline 1015 & 913.38 & 903.27 & $\begin{array}{l}---- \\
-----\end{array}$ & - & 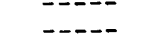 \\
\hline 1020 & 913.38 & 903.26 & ---- & 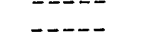 & ---- \\
\hline 1025 & 913.38 & 903.25 & ---- & --- & --- \\
\hline 1030 & 913.38 & 903.24 & - & $-\ldots$ & 880.72 \\
\hline 1035 & 913.38 & 903.24 & $-2-1$ & 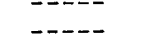 & - \\
\hline 1040 & 913.38 & 903.25 & --- & $---\infty$ & ---- \\
\hline 1045 & 913.38 & 903.23 & 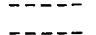 & $-\cdots$ & ---- \\
\hline 1050 & 913.38 & 903.23 & 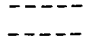 & $-\cdots$ & $-\cdots$ \\
\hline 1055 & 913.38 & 903.23 & ----- & $-\cdots--$ & ----- \\
\hline 1100 & 913.38 & 903.24 & ----- & ---0 & ----- \\
\hline 1105 & 913.38 & 903.23 & ---0 & ---- & ----0 \\
\hline 1110 & 913.38 & 903.21 & ----- & ---- & ---- \\
\hline 1115 & 913.38 & 903.22 & ---- & ----- & ----- \\
\hline 1120 & 913.38 & 903.23 & $-\cdots$ & ----- & $\cdots-\cdots$ \\
\hline 1125 & 913.38 & 903.22 & ---- & ----- & ----- \\
\hline 1130 & 913.38 & 903.22 & 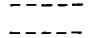 & $-\cdots$ & $8 \overline{80.73}$ \\
\hline 1135 & 913.38 & 903.21 & $--1-2$ & $--1--$ & - \\
\hline 1140 & 913.38 & 903.21 & ---- & ----- & --1 \\
\hline 1145 & 913.38 & 903.20 & $--\infty--$ & --ー-- & ----- \\
\hline 1150 & 913.38 & 903.20 & ---- & ----- & ----- \\
\hline 1155 & 913.38 & 903.21 & $-0-1$ & 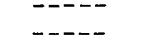 & ----- \\
\hline 1200 & 913.39 & 903.18 & 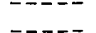 & ---- & $\overline{880} \overline{7} \overline{3}$ \\
\hline 1205 & 913.39 & 903.18 & ----- & ----- & 000.10 \\
\hline 1210 & 913.39 & 903.17 & $---2-$ & ----- & ----- \\
\hline 1215 & 913.39 & 903.17 & ----- & $\cdots--$ & $-\cdots$ \\
\hline 1220 & 913.39 & 903.19 & ----- & $\cdots--$ & ----- \\
\hline 1225 & 913.39 & 903.17 & ----- & ---- & $-\cdots-$ \\
\hline 1230 & 913.39 & 903.17 & ----- & $-\cdots$ & $\overrightarrow{800} \overline{74}$ \\
\hline 1235 & 913.39 & 903.18 & ----- & ----- & 880.74 \\
\hline 1240 & 913.39 & 903.16 & $\cdots--$ & ----- & ---- \\
\hline 1245 & 913.39 & 903.17 & $-\ldots-$ & ---- & ----- \\
\hline 1250 & 91339 & $\begin{array}{l}903.17 \\
00215\end{array}$ & ---- & ---- & ----- \\
\hline 1250 & & 903.15 & - - - & -.... & ---- \\
\hline 1255 & 913.39 & 903.15 & ---- & ----- & -.-.- \\
\hline 1300 & 913.39 & 903.16 & ---- & ----- & 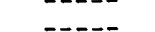 \\
\hline 1305 & 913.39 & 903.16 & ---- & ----- & 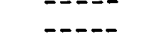 \\
\hline 1310 & 913.39 & 903.16 & ----- & 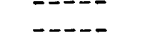 & $\begin{array}{ll}----2 \\
---n\end{array}$ \\
\hline 1315 & 913.39 & 903.15 & $\begin{array}{l}----- \\
---1-\end{array}$ & $\begin{array}{ll}--1-- \\
---1\end{array}$ & 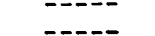 \\
\hline 1320 & 913.39 & 903.15 & $\begin{array}{l}---\infty \\
---\infty\end{array}$ & 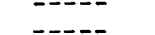 & 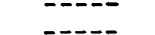 \\
\hline 1325 & 913.39 & 903.16 & $\begin{array}{l}---\infty \\
---n--\end{array}$ & 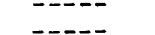 & ----- \\
\hline 1330 & 913.39 & 903.14 & $\begin{array}{l}----- \\
-\ldots--\end{array}$ & 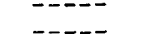 & $880.7 \overline{6}$ \\
\hline 1335 & 913.39 & 903.14 & ----- & --- & 00000 \\
\hline 1340 & 913.39 & 903.13 & ----- & 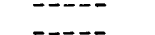 & ----- \\
\hline 1345 & 913.39 & 903.13 & 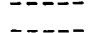 & ----- & ---- \\
\hline 1350 & 913.39 & 903.14 & ---- & ----- & ---- \\
\hline 1355 & 913.39 & 903.13 & ----- & ---- & ----- \\
\hline 1400 & 913.38 & 903.12 & ----- & $\cdots-$ & ---- \\
\hline 1405 & 913.38 & 903.13 & $-\cdots$ & ---- & $-\cdots-$ \\
\hline 1410 & 913.38 & 903.13 & ----- & $\cdots-$ & --- \\
\hline & & & $-\cdots--$ & ---- & - \\
\hline
\end{tabular}


TABLE 10.-Summary of river stage data-Continued

\begin{tabular}{|c|c|c|c|c|c|}
\hline \multirow[b]{2}{*}{$\begin{array}{l}\text { Date and } \\
\text { Time }\end{array}$} & \multicolumn{5}{|c|}{ Water-surface altitude, in feet } \\
\hline & $\begin{array}{c}\text { Buford } \\
\text { Dam }\end{array}$ & $\begin{array}{c}\text { Georgia } \\
\text { Highway } 20\end{array}$ & $\begin{array}{l}\text { Littles } \\
\text { Ferry } \\
\text { Bridge }\end{array}$ & $\begin{array}{c}\text { Georgia } \\
\text { Highway } 120\end{array}$ & $\begin{array}{c}\text { Georgia } \\
\text { Highway } 141\end{array}$ \\
\hline \multicolumn{6}{|l|}{ March 21, 1976: } \\
\hline 1415 & 913.38 & 903.12 & $\ldots-$ & ---- & ---- \\
\hline 1420 & 913.38 & 903.12 & $---n$ & ----- & 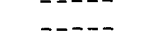 \\
\hline 1425 & 913.38 & 903.11 & $\begin{array}{ll}---n-1 \\
---n\end{array}$ & $\begin{array}{ll}-1--- \\
-n-1\end{array}$ & \\
\hline 1430 & 913.38 & 903.12 & ---- & ---- & 880.81 \\
\hline 1435 & 913.38 & 903.12 & $-\ldots-$ & $-\ldots$ & ---- \\
\hline 1440 & 913.38 & 903.12 & ---- & ---- & ---- \\
\hline 1445 & 913.38 & 903.12 & ---- & ---- & ---- \\
\hline 1450 & 913.38 & 903.12 & ----- & $-\ldots-$ & ---- \\
\hline 1455 & 913.38 & 903.11 & $-\ldots-$ & $\ldots \ldots$ & $---n$ \\
\hline 1500 & 913.38 & 903.11 & $\ldots \ldots$ & - & $--\ldots$ \\
\hline 1505 & 913.38 & 903.10 & 893.50 & - & $\ldots$ \\
\hline 1510 & 913.38 & 903.10 & 893.50 & - n- & 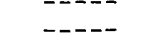 \\
\hline 1515 & 913.38 & 903.10 & 893.50 & 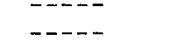 & ---- \\
\hline 1520 & 913.38 & 903.10 & 893.50 & 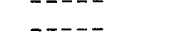 & ---1 \\
\hline 1525 & 913.38 & 903.10 & & $\ldots$ & ----- \\
\hline 1530 & 913.38 & 903.10 & 893.49 & $\ldots \ldots$ & 880.84 \\
\hline 1535 & 913.38 & 903.11 & & $\ldots \ldots$ & $\ldots---$ \\
\hline 1540 & 913.38 & 903.09 & 893.48 & - & $-\ldots--$ \\
\hline 1545 & 913.38 & 903.10 & & ----- & - . - - \\
\hline 1550 & 913.38 & 903.09 & 893.47 & --- & $-\ldots$ \\
\hline 1555 & 913.38 & 903.10 & & ---- & - \\
\hline 1600 & 913.38 & 903.10 & 893.45 & 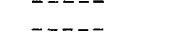 & - \\
\hline 1605 & 913.38 & 903.09 & - - - - & $-\cdots-$ & 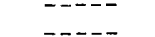 \\
\hline 1610 & 913.38 & 903.09 & 893.45 & $\ldots \ldots$ & - . - - \\
\hline 1615 & 913.38 & 903.09 & & --- & ----- \\
\hline 1620 & 913.38 & 903.09 & 893.41 & $\ldots \ldots$ & ---- \\
\hline 1625 & 913.38 & 903.09 & & $\ldots-\ldots$ & - \\
\hline 1630 & 913.38 & 903.09 & 893.41 & ---- & 880.85 \\
\hline 1635 & 913.38 & 903.08 & & 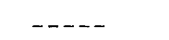 & ----- \\
\hline 1640 & 913.38 & 903.09 & 893.41 & ----- & ---- \\
\hline 1645 & 913.38 & 903.08 & & ----- & ----- \\
\hline 1650 & 913.38 & 903.08 & 893.42 & ----- & ----- \\
\hline 1655 & 913.38 & 903.08 & & ----- & ---- \\
\hline 1700 & 913.38 & 903.08 & 893.41 & ----- & ----- \\
\hline 1705 & 913.38 & 903.08 & & $\ldots \ldots$ & $\ldots \ldots$ \\
\hline 1710 & 913.38 & 903.08 & 893.39 & ---- & $\ldots--$ \\
\hline 1715 & 913.38 & 903.08 & & ---- & $---\cdots$ \\
\hline 1720 & 913.38 & 903.07 & 893.39 & -.-- & $-\ldots$ \\
\hline 1725 & 913.38 & 903.08 & ---- & $\ldots \ldots$ & $-\ldots-$ \\
\hline 1730 & 913.38 & 903.07 & 893.38 & --- & 880.84 \\
\hline 1735 & 913.38 & 903.07 & & ----- & $---n-$ \\
\hline 1740 & 913.38 & 903.07 & 893.37 & ---- & ---- \\
\hline 1745 & 913.38 & 903.07 & & $\ldots$ & --- \\
\hline 1750 & 913.38 & 903.07 & 893.36 & $\ldots-\ldots$ & $\ldots$ \\
\hline 1755 & 913.38 & 903.07 & & ----- & ----- \\
\hline 1800 & 913.38 & 903.07 & 893.36 & --- & --- \\
\hline 1805 & 913.38 & 903.07 & & ----- & - - - - \\
\hline 1810 & 913.38 & 903.07 & 893.36 & - - - - & - - - - \\
\hline 1815 & 913.38 & 903.07 & & ---- & ---1 \\
\hline 1820 & 913.38 & 903.07 & 893.36 & $\ldots-\ldots$ & ----- \\
\hline 1825 & 913.38 & 903.07 & & $\ldots .$. & $\ldots$ \\
\hline 1830 & 913.38 & 903.07 & 893.33 & ---- & 880.83 \\
\hline 1835 & 913.38 & 903.07 & ----- & ---- & $-\cdots$ \\
\hline 1840 & 913.38 & 903.07 & 893.33 & --- & ---- \\
\hline 1845 & 913.38 & 903.07 & & $\ldots--$ & ----- \\
\hline 1850 & 913.38 & 903.07 & 893.32 & - & ---- \\
\hline 1855 & 913.38 & 903.07 & $-\cdots$ & ---- & $\ldots-$ \\
\hline
\end{tabular}


TABLE 10.-Summary of river stage data-Continued

\begin{tabular}{|c|c|c|c|c|c|}
\hline \multirow[b]{2}{*}{$\begin{array}{l}\text { Date and } \\
\text { Time }\end{array}$} & \multicolumn{5}{|c|}{ Water-surface altitude, in feet } \\
\hline & $\begin{array}{c}\text { Buford } \\
\text { Dam }\end{array}$ & $\begin{array}{c}\text { Georgia } \\
\text { Highway } 20\end{array}$ & $\begin{array}{l}\text { Littles } \\
\text { Ferry } \\
\text { Bridge }\end{array}$ & $\begin{array}{c}\text { Georgia } \\
\text { Highway } 120\end{array}$ & $\begin{array}{c}\text { Georgia } \\
\text { Highway } 141\end{array}$ \\
\hline \multicolumn{6}{|c|}{ March 21, 1976: } \\
\hline 1900 & 913.38 & 903.07 & 893.33 & ---- & ---- \\
\hline 1905 & 913.38 & 903.07 & - & 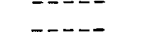 & 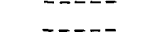 \\
\hline 1910 & 913.38 & 903.07 & ----- & ---- & ---- \\
\hline 1915 & 913.38 & 903.07 & ----- & ---- & $\begin{array}{ll}---n-- \\
---n\end{array}$ \\
\hline 1920 & 913.38 & 903.07 & 893.30 & 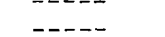 & 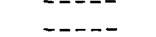 \\
\hline 1925 & 913.38 & 903.06 & & ----- & ----- \\
\hline 1930 & 913.38 & 903.06 & 893.29 & $-\ldots-1$ & 880.81 \\
\hline 1935 & 913.38 & 903.06 & & ---- & - \\
\hline 1940 & 913.38 & 903.06 & 893.29 & ----- & ---- \\
\hline 1945 & 913.38 & 903.06 & & $--1-$ & $\ldots-$ \\
\hline 1950 & 913.38 & 903.06 & 893.29 & 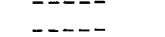 & $-\ldots$ \\
\hline 1955 & 913.38 & 903.06 & & - & 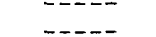 \\
\hline 2000 & 913.38 & 903.06 & $\overline{893.2 \overline{8}}$ & $-\cdots$ & ---- \\
\hline 2005 & 913.38 & 903.06 & & - & --- \\
\hline 2010 & 913.38 & 903.06 & $893 . \overline{2}$ & 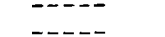 & --n \\
\hline 2015 & 913.38 & 903.06 & & ---- & $\begin{array}{ll}---1 \\
---1\end{array}$ \\
\hline 2020 & 913.38 & 903.06 & $\overline{893 . \overline{2}}$ & $-\cdots--$ & 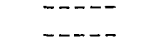 \\
\hline 2025 & 913.38 & 903.06 & & $-\ldots-$ & 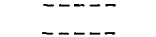 \\
\hline 2030 & 913.38 & 903.06 & 893.26 & ---- & $880 . \overline{7}$ \\
\hline 2035 & 913.38 & 903.06 & & $-\ldots$ & _- \\
\hline 2040 & 913.38 & 903.06 & $893.2 \overline{5}$ & --- & - \\
\hline 2045 & 913.38 & 903.06 & & ----- & ----- \\
\hline 2050 & 913.38 & 903.06 & 893.25 & 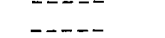 & 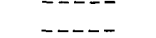 \\
\hline 2055 & 913.38 & 903.06 & & $\begin{array}{l}--m-1 \\
-\ldots-\ldots-\end{array}$ & 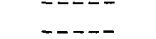 \\
\hline 2100 & 913.38 & 903.06 & $8 \overline{83.2 \overline{5}}$ & - & $\begin{array}{l}----- \\
-----\end{array}$ \\
\hline 2105 & 913.38 & 903.06 & - - - - - & $\ldots-\ldots$ & - \\
\hline 2110 & 913.38 & 903.06 & 893.25 & 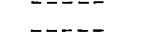 & $\ldots$ \\
\hline 2115 & 913.38 & 903.05 & & - & $\begin{array}{l}--2-- \\
--1--\end{array}$ \\
\hline 2120 & 913.38 & 903.05 & 893.24 & $-\ldots-$ & - \\
\hline 2125 & 913.38 & 903.05 & & 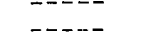 & - \\
\hline 2130 & 913.38 & 903.05 & 893.23 & - - - - & $880 . \overline{74}$ \\
\hline 2135 & 913.38 & 903.05 & & ----- & - ---- \\
\hline 2140 & 913.38 & 903.05 & $893 . \overline{3}$ & $\begin{array}{l}----- \\
-----\end{array}$ & - \\
\hline 2145 & 913.38 & 903.05 & & - & $-\cdots$ \\
\hline 2150 & 913.38 & 903.05 & $8 \overline{93.22}$ & - & $-\cdots--$ \\
\hline 2155 & 913.38 & 903.05 & 070.22 & $\begin{array}{l}----- \\
--1--\end{array}$ & $--\cdots$ \\
\hline 2200 & 913.38 & 903.05 & ---1 & $-\cdots--$ & $-\cdots-$ \\
\hline 2205 & 913.38 & 903.05 & $-\cdots--$ & ---- & $-\cdots$ \\
\hline 2210 & 913.38 & 903.05 & $\overline{893.2 \overline{2}}$ & ----- & $-\cdots-$ \\
\hline 2215 & 913.38 & 903.05 & $\begin{array}{c}893.22 \\
-\end{array}$ & $--\cdots$ & - \\
\hline 2220 & 913.38 & 903.05 & $\overline{893.22}$ & $\begin{array}{l}---0- \\
-----\end{array}$ & $-\cdots$ \\
\hline 2225 & 913.38 & 903.05 & & $-0--$ & $---\cdots$ \\
\hline 2230 & 913.38 & 903.05 & $8 \overline{9} . \overline{2} \overline{2}$ & 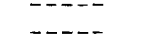 & $8 \overline{80.69}$ \\
\hline 2235 & 913.38 & 903.05 & & ---0 & 000.00 \\
\hline 2240 & 913.38 & 903.05 & $\overline{893.2 \overline{2}}$ & - & $\cdots$ \\
\hline 2245 & 913.38 & 903.05 & & ----- & $-\cdots$ \\
\hline 2250 & 913.38 & 903.05 & 893.21 & ----0 & $-\cdots--$ \\
\hline 2255 & 913.38 & 903.05 & 000.21 & ----- & ----- \\
\hline 2300 & 913.38 & 903.05 & $\overline{893.2 \overline{1}}$ & - - - & $-\cdots$ \\
\hline 2305 & 913.38 & 903.05 & 893.21 & $-\cdots--$ & $--\cdots-$ \\
\hline 2310 & 913.38 & 903.05 & $\overline{893 . \overline{1}}$ & ---- & $-\cdots--$ \\
\hline 2315 & 913.38 & 903.04 & & ---- & $-\cdots-$ \\
\hline 2320 & 913.38 & 903.04 & $893 . \overline{2}$ & $-\cdots-$ & ---- \\
\hline 2325 & 913.38 & 903.04 & & ---- & $-\cdots--$ \\
\hline 2330 & 913.38 & 903.04 & 893.21 & 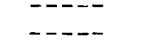 & $8 \overline{80 . \overline{6}}$ \\
\hline 2335 & 913.38 & 903.04 & _... & ---- & 2000 \\
\hline 2340 & 913.38 & 903.04 & 893.20 & - & ----- \\
\hline
\end{tabular}


TABLE 10.-Summary of river stage data-Continued

\begin{tabular}{|c|c|c|c|c|c|}
\hline \multirow[b]{2}{*}{$\begin{array}{c}\text { Date and } \\
\text { Time }\end{array}$} & \multicolumn{5}{|c|}{ Water-surface altitude, in feet } \\
\hline & $\begin{array}{c}\text { Buford } \\
\text { Dam }\end{array}$ & $\begin{array}{c}\text { Georgia } \\
\text { Highway } 20\end{array}$ & $\begin{array}{l}\text { Littles } \\
\text { Ferry } \\
\text { Bridge }\end{array}$ & $\begin{array}{c}\text { Georgia } \\
\text { Highway } 120\end{array}$ & $\begin{array}{c}\text { Georgia } \\
\text { Highway } 141\end{array}$ \\
\hline \multicolumn{6}{|c|}{ March 21, 1976: } \\
\hline 2345 & 913.38 & 903.04 & & ---- & -...- \\
\hline 2350 & 913.38 & 903.04 & 893.20 & ---- & $-\ldots--$ \\
\hline 2355 & 913.38 & 903.04 & & ----- & ----- \\
\hline 2400 & 913.38 & 903.04 & 893.19 & ---- & ---- \\
\hline \multicolumn{6}{|c|}{ March 22, 1976: } \\
\hline 0005 & 913.38 & 903.04 & & ----- & $-\ldots-$ \\
\hline 0010 & 913.38 & 903.04 & 893.19 & 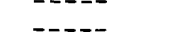 & 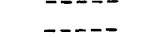 \\
\hline 0015 & 913.38 & 903.04 & & 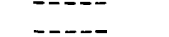 & 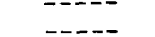 \\
\hline 0020 & 913.38 & 903.04 & $8 \overline{3} .1 \overline{9}$ & ----- & 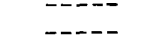 \\
\hline 0025 & 913.38 & 903.04 & & ----- & ----- \\
\hline 0030 & 913.38 & 903.03 & 893.18 & ----- & 880.61 \\
\hline 0035 & 913.38 & 903.03 & & - & $-\ldots-n$ \\
\hline 0040 & 913.38 & 903.03 & 893.18 & ---- & ---- \\
\hline 0045 & 913.38 & 903.03 & & $\ldots$ & $\ldots \ldots$ \\
\hline 0050 & 913.38 & 903.03 & 893.18 & ----- & ----- \\
\hline 0055 & 913.38 & 903.03 & & $---\ldots$ & ----- \\
\hline 0100 & 913.38 & 903.03 & 893.18 & - & $\ldots \ldots$ \\
\hline 0105 & 913.38 & 903.03 & & - - - - & ---1 \\
\hline 0110 & 913.38 & 903.03 & 893.17 & $\ldots \ldots$ & $\ldots$ \\
\hline 0115 & 913.38 & 903.03 & &.--- & $\ldots--$ \\
\hline 0120 & 913.38 & 903.03 & 893.17 & 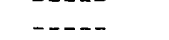 & ---- \\
\hline 0125 & 913.38 & 903.03 & & ---- &.---- \\
\hline 0130 & 913.38 & 903.03 & 893.17 & $\ldots \ldots$ & 880.56 \\
\hline 0135 & 913.38 & 903.03 & & ---- & ---- \\
\hline 0140 & 913.38 & 903.03 & 893.17 & ---- & ----- \\
\hline 0145 & 913.38 & 903.03 & & ----- & $-\ldots$ \\
\hline 0150 & 913.38 & 903.03 & 893.17 & ----- & $\ldots-$ \\
\hline 0155 & 913.38 & 903.03 & & ----- & $\ldots$ \\
\hline 0200 & 913.38 & 903.03 & 893.17 & $-1--$ & $\ldots-$ \\
\hline 0205 & 913.38 & 903.03 & & ----- & 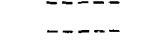 \\
\hline 0210 & 913.38 & 903.03 & 893.17 & $-\ldots-$ & $-\ldots$ \\
\hline 0215 & 913.38 & 903.03 & & ---- & - \\
\hline 0220 & 913.38 & 903.03 & 893.17 & ----- & $-\ldots-n$ \\
\hline 0225 & 913.38 & 903.03 & & ----- & 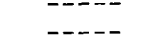 \\
\hline 0230 & 913.38 & 903.03 & 893.17 & - - - - & $880.5 \overline{2}$ \\
\hline 0235 & 913.38 & 903.03 & & ----- & 000.00 \\
\hline 0240 & 913.38 & 903.03 & 893.16 & 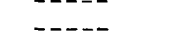 & $-\ldots-$ \\
\hline 0245 & 913.38 & 903.03 & & 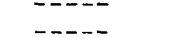 & 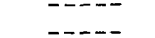 \\
\hline 0250 & 913.38 & 903.03 & 893.16 & ----- & ----- \\
\hline 0255 & 913.38 & 903.03 & & ----- & 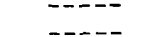 \\
\hline 0300 & 913.38 & 903.03 & 893.15 & ---- & 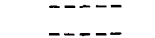 \\
\hline 0305 & 913.38 & 903.03 & & ----- & 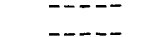 \\
\hline 0310 & 913.38 & 903.03 & $893.1 \overline{5}$ & $\begin{array}{l}----- \\
-----\end{array}$ & ---- \\
\hline 0315 & 913.38 & 903.03 & & - ---- & - \\
\hline 0320 & 913.38 & 903.03 & 893.16 & ---- & ---- \\
\hline 0325 & 913.38 & 903.03 & & $\ldots--$ & - \\
\hline 0330 & 913.38 & 903.03 & 893.16 & $-\ldots$ & 880.48 \\
\hline 0335 & 913.38 & 903.03 & $-\cdots-=$ & ---- & $\ldots--$ \\
\hline 0340 & 913.38 & 903.03 & 893.15 & - - - & ----- \\
\hline 0345 & 910.38 & 903.03 & & ----- & $\ldots \ldots$ \\
\hline 0350 & 913.38 & 903.03 & 893.15 & $\ldots$ & ---- \\
\hline 0355 & 913.38 & 903.03 & & ---- & ----- \\
\hline 0400 & 913.38 & 903.03 & 893.15 & ----- & ---- \\
\hline 0405 & 913.38 & 903.03 & & $\ldots$ & -... \\
\hline 0410 & 913.38 & 903.03 & 893.14 & $-\ldots$ & 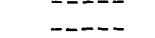 \\
\hline 0415 & 913.38 & 903.03 & $\ldots \ldots$ & $\ldots$ & --- \\
\hline
\end{tabular}


TABLE 10.-Summary of river stage data-Continued

\begin{tabular}{|c|c|c|c|c|c|}
\hline \multirow[b]{2}{*}{$\begin{array}{l}\text { Date and } \\
\text { Time }\end{array}$} & \multicolumn{5}{|c|}{ Water-surface altitude, in feet } \\
\hline & $\begin{array}{l}\text { Buford } \\
\text { Dam }\end{array}$ & $\begin{array}{c}\text { Georgia } \\
\text { Highway } 20\end{array}$ & $\begin{array}{l}\text { Littles } \\
\text { Ferry } \\
\text { Bridge }\end{array}$ & $\begin{array}{c}\text { Georgia } \\
\text { Highway } 120\end{array}$ & $\begin{array}{r}\text { Georgia } \\
\text { Highway } 1\end{array}$ \\
\hline \multicolumn{6}{|c|}{ March 22, 1976: } \\
\hline 0420 & 913.38 & 903.03 & 893.14 & $\ldots \ldots$ & $-m---$ \\
\hline 0425 & 913.38 & 903.03 & & ----- & \\
\hline 0430 & 913.38 & 903.03 & 893.15 & $-\ldots-$ & 880.46 \\
\hline 0435 & 913.38 & 903.03 & & $\ldots-\ldots$ & ----- \\
\hline 0440 & 913.38 & 903.03 & 893.15 & $-\ldots--$ & ---- \\
\hline 0445 & 913.38 & 903.03 & & $\ldots-\ldots$ & $-\ldots--$ \\
\hline 0450 & 913.38 & 903.03 & 893.12 & - - - & $---\cdots$ \\
\hline 0455 & 913.38 & 903.03 & & ---- & ----- \\
\hline 0500 & 913.38 & 903.03 & 893.12 & $\ldots \ldots$ & $-\ldots--$ \\
\hline 0505 & 913.38 & 903.03 & & ----- & ----- \\
\hline 0510 & 913.38 & 903.03 & 893.12 & - & ---- \\
\hline 0515 & 913.38 & 903.03 & & 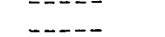 & 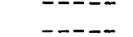 \\
\hline 0520 & 913.38 & 903.03 & 893.12 & $-\ldots$ & ---- \\
\hline 0525 & 913.38 & 903.03 & & - & \\
\hline 0530 & 913.38 & 903.03 & 893.11 & $-1--$ & 880.44 \\
\hline 0535 & 913.38 & 903.03 & & $---\cdots$ & - - - \\
\hline 0540 & 913.38 & 903.03 & 893.10 & - & $\ldots---$ \\
\hline 0545 & 913.38 & 903.03 & & $\ldots---$ & ---- \\
\hline 0550 & 913.38 & 903.03 & 893.11 & ---- & ---- \\
\hline 0555 & 913.38 & 903.03 & & - - - - & - \\
\hline 0600 & 913.38 & 903.09 & 893.11 & - - - - & ---- \\
\hline 0605 & 913.38 & 903.03 & & 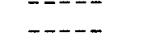 & $\begin{array}{l}----- \\
-----\end{array}$ \\
\hline 0610 & 913.38 & 903.03 & 893.11 & - & 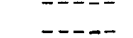 \\
\hline 0615 & 913.38 & 903.03 & & $-\ldots$ & 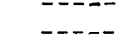 \\
\hline 0620 & 913.38 & 903.03 & 893.11 & $--1-$ & 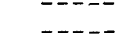 \\
\hline 0625 & 913.38 & 903.03 & & $\ldots-\ldots$ & \\
\hline 0630 & 913.38 & 903.03 & 893.11 & ---- & 880.41 \\
\hline 0635 & 913.38 & 903.02 & & ----- & - \\
\hline 0640 & 913.38 & 903.02 & 893.11 & ---1 & ----- \\
\hline 0645 & 913.38 & 903.02 & & 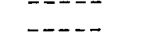 & $\begin{array}{l}----- \\
-----\end{array}$ \\
\hline 0650 & 913.38 & 903.02 & 893.11 & $--1-$ & ---1 \\
\hline 0655 & 913.51 & 903.02 & & - & $\begin{array}{l}----- \\
-----\end{array}$ \\
\hline 0700 & 914.57 & 903.02 & 893.11 & $\begin{array}{ll}--n-1 \\
-\cdots-1\end{array}$ & $\begin{array}{l}----- \\
-----\end{array}$ \\
\hline 0705 & 915.60 & 903.02 & & $\cdots$ & ----- \\
\hline 0710 & 916.10 & 903.02 & 893.11 & $\begin{array}{ll}----- \\
----\end{array}$ & $\begin{array}{l}----- \\
--n--\end{array}$ \\
\hline 0715 & 916.29 & 903.05 & & - & 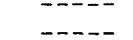 \\
\hline 0720 & 916.39 & 903.23 & 893.11 & 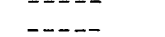 & $\begin{array}{l}---- \\
--n-\end{array}$ \\
\hline 0725 & 916.45 & 903.62 & & $\begin{array}{l}----1 \\
-\cdots--\end{array}$ & 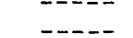 \\
\hline 0730 & 916.48 & 904.10 & 893.11 & ---- & 880.39 \\
\hline 0735 & 916.50 & 904.57 & & 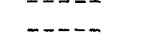 & --- - \\
\hline 0740 & 916.52 & 904.97 & 893.11 & 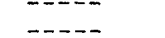 & $\begin{array}{ll}---0 \\
-n--1\end{array}$ \\
\hline 0745 & 916.52 & 905.32 & & $--n$ & \\
\hline 0750 & 916.52 & 905.62 & 893.11 & ---- & $\begin{array}{l}----- \\
-----\end{array}$ \\
\hline 0755 & 916.52 & 905.86 & & 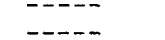 & \\
\hline 0800 & 916.54 & 906.09 & 893.11 & $\begin{array}{l}---m \\
----\end{array}$ & $\begin{array}{l}----1 \\
-----\end{array}$ \\
\hline 0805 & 916.54 & 906.29 & & 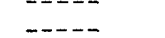 & $\begin{array}{l}----- \\
--n-\end{array}$ \\
\hline 0810 & 916.55 & 906.47 & 893.11 & $-\ldots$ & $\begin{array}{l}--n-2 \\
--n-\end{array}$ \\
\hline 0815 & 916.54 & 906.63 & & $----m$ & $\begin{array}{l}---\infty \\
--n--\end{array}$ \\
\hline 0820 & 916.55 & 906.77 & $\overline{893.1 \overline{1}}$ & $--\infty-\infty$ & $-\cdots--$ \\
\hline 0825 & 916.54 & 906.89 & & 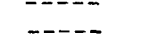 & 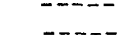 \\
\hline 0830 & 916.54 & 907.01 & 893.11 & $-\ldots$ & $880.3 \overline{7}$ \\
\hline 0835 & 916.55 & 907.12 & $\ldots$ & --- & - \\
\hline 0840 & 916.55 & 907.21 & 893.11 & 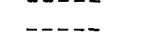 & ---- \\
\hline 0845 & 916.55 & 907.30 & & 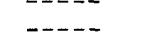 & ---- \\
\hline 0850 & 916.56 & 907.38 & 893.12 & $\ldots-\ldots$ & - \\
\hline 0855 & 916.56 & 907.45 & & $\ldots-\ldots$ & $-1--$ \\
\hline 0900 & 916.56 & 907.50 & 893.13 & $---n$ & $-\cdots-$ \\
\hline
\end{tabular}


TABLE 10.-Summary of river stage data-Continued

\begin{tabular}{|c|c|c|c|c|c|}
\hline \multirow[b]{2}{*}{$\begin{array}{l}\text { Date and } \\
\text { Time }\end{array}$} & \multicolumn{5}{|c|}{ Water-surface altitude, in feet } \\
\hline & $\begin{array}{l}\text { Buford } \\
\text { Dam }\end{array}$ & $\begin{array}{c}\text { Georgia } \\
\text { Highway } 20\end{array}$ & $\begin{array}{l}\text { Littles } \\
\text { Ferry } \\
\text { Bridge }\end{array}$ & $\begin{array}{c}\text { Georgia } \\
\text { Highway } 120\end{array}$ & $\begin{array}{c}\text { Georgia } \\
\text { Highway } 141\end{array}$ \\
\hline \multicolumn{6}{|c|}{ March 22, 1976: } \\
\hline 0905 & 916.56 & 907.62 & & ----- & ----- \\
\hline 0910 & 916.56 & 907.68 & 893.16 & ----- & ---- \\
\hline 0915 & 916.56 & 907.74 & & ----- & ----- \\
\hline 0920 & 916.56 & 907.80 & 893.28 & ----- & ----- \\
\hline 0925 & 916.56 & 907.86 & & $-\ldots-\infty$ & \\
\hline 0930 & 916.57 & 907.91 & 893.39 & $\ldots-\ldots$ & 880.36 \\
\hline 0935 & 916.56 & 907.96 & & & ----- \\
\hline 0940 & 916.57 & 908.00 & 893.59 & 885.32 & ----1 \\
\hline 0945 & 916.57 & 908.04 & & 885.32 & $\ldots-\ldots$ \\
\hline 0950 & 916.57 & 908.08 & 893.84 & 885.31 & ----- \\
\hline 0955 & 916.57 & 908.13 & & 885.31 & $-\ldots-$ \\
\hline 1000 & 916.58 & 908.16 & 894.23 & 885.31 & ---- \\
\hline 1005 & 916.58 & 908.20 & & 885.31 & ---- \\
\hline 1010 & 916.58 & 908.24 & 894.53 & 885.31 & $--\ldots$ \\
\hline 1015 & 916.58 & 908.26 & & 885.31 & $-1-1$ \\
\hline 1020 & 916.58 & 908.30 & 894.92 & 885.31 & $\begin{array}{l}---0- \\
--1--\end{array}$ \\
\hline 1025 & 916.58 & 908.32 & & 885.32 & \\
\hline 1030 & 916.58 & 908.36 & 895.32 & 885.34 & 880.35 \\
\hline 1035 & 916.57 & 908.39 & & 885.36 & ----- \\
\hline 1040 & 916.58 & 908.40 & 895.72 & 885.39 & ---- \\
\hline 1045 & 916.58 & 908.42 & & 885.41 & ---- \\
\hline 1050 & 916.58 & 908.44 & 896.03 & 885.43 & ---- \\
\hline 1055 & 916.58 & 908.47 & & 885.48 & 880.34 \\
\hline 1100 & 916.58 & 908.49 & 896.22 & 885.53 & _. \\
\hline 1105 & 916.59 & 908.51 & & 885.59 & - \\
\hline 1110 & 916.58 & 908.53 & 895.56 & 885.66 & 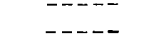 \\
\hline 1115 & 916.58 & 908.55 & & 885.73 & 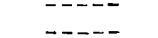 \\
\hline 1120 & 916.58 & 908.56 & 896.80 & 885.80 & - \\
\hline 1125 & 916.58 & 908.57 & & 885.89 & ----- \\
\hline 1130 & 916.58 & 908.59 & 897.01 & 885.97 & 880.34 \\
\hline 1135 & 916.58 & 908.61 & & 886.08 & - \\
\hline 1140 & 916.58 & 908.62 & 897.19 & 886.20 & 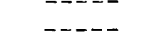 \\
\hline 1145 & 916.58 & 908.62 & & 886.32 & $\begin{array}{l}----- \\
-----\end{array}$ \\
\hline 1150 & 916.58 & 908.65 & 897.37 & 886.43 & 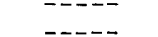 \\
\hline 1155 & 916.58 & 908.66 & & 886.56 & $\begin{array}{l}---2- \\
----2\end{array}$ \\
\hline 1200 & 916.58 & 908.67 & 897.53 & 886.71 & 880.39 \\
\hline 1205 & 916.58 & 908.68 & & 886.82 & - \\
\hline 1210 & 916.58 & 908.68 & 897.68 & 886.94 & ----- \\
\hline 1215 & 916.58 & 908.70 & & 887.11 & 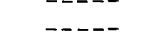 \\
\hline 1220 & 916.58 & 908.71 & 897.89 & 887.29 & $\begin{array}{l}---0- \\
--\cdots--\end{array}$ \\
\hline 1225 & 916.58 & 908.72 & & 887.40 & \\
\hline 1230 & 916.58 & 908.72 & 897.98 & 887.51 & 880.50 \\
\hline 1235 & 916.58 & 908.73 & & 887.65 & 000.00 \\
\hline 1240 & 916.59 & 908.74 & 898.13 & 887.79 & $-\cdots--$ \\
\hline 1245 & 916.58 & 908.75 & & 887.91 & $-\cdots--$ \\
\hline 1250 & 916.59 & 908.76 & 898.14 & 888.04 & - \\
\hline 1255 & 916.58 & 908.76 & & 888.19 & ----- \\
\hline 1300 & 916.58 & 908.77 & $\overline{898.2 \overline{8}}$ & 888.30 & ----- \\
\hline 1305 & 916.59 & 908.78 & & $\begin{array}{l}080.00 \\
888.41\end{array}$ & ---- \\
\hline 1310 & 916.59 & 908.78 & 898.31 & 888.51 & ---- \\
\hline 1315 & 916.59 & 908.78 & & 888.61 & $\begin{array}{l}---\infty \\
-----\end{array}$ \\
\hline 1320 & 916.59 & 908.79 & 898.46 & 888.71 & $---n$ \\
\hline 1325 & 916.58 & 908.79 & & 888.81 & $m-\cdots$ \\
\hline 1330 & 916.58 & 908.80 & 898.51 & 888.90 & 880.94 \\
\hline 1335 & 916.58 & 908.81 & & 889.00 & \\
\hline 1340 & 916.58 & 908.81 & 898.53 & 889.09 & $-\cdots--$ \\
\hline 1345 & 916.59 & 908.81 & - & 889.18 & ---n- \\
\hline
\end{tabular}


TABLE 10.-Summary of river stage data-Continued

\begin{tabular}{|c|c|c|c|c|c|}
\hline \multirow[b]{2}{*}{$\begin{array}{l}\text { Date and } \\
\text { Time }\end{array}$} & \multicolumn{5}{|c|}{ Water-surface altitude, in feet } \\
\hline & $\begin{array}{l}\text { Buford } \\
\text { Dam }\end{array}$ & $\begin{array}{c}\text { Georgia } \\
\text { Highway } 20\end{array}$ & $\begin{array}{l}\text { Littles } \\
\text { Ferry } \\
\text { Bridge }\end{array}$ & $\begin{array}{c}\text { Georgia } \\
\text { Highway } 120\end{array}$ & $\begin{array}{c}\text { Georgia } \\
\text { Highway } 141\end{array}$ \\
\hline \multicolumn{6}{|c|}{ March 22, 1976: } \\
\hline 1350 & 916.59 & 908.81 & 898.62 & 889.28 & ----- \\
\hline 1355 & 916.59 & 908.82 & & 889.36 & ----- \\
\hline 1400 & 916.59 & 908.83 & 898.64 & 889.44 & ---- \\
\hline 1405 & 916.59 & 908.83 & & 889.51 & ---1 \\
\hline 1410 & 916.58 & 908.83 & 898.66 & 889.58 & ----- \\
\hline 1415 & 916.59 & 908.83 & & 889.64 & \\
\hline 1420 & 916.59 & 908.83 & 898.76 & 889.70 & 881.96 \\
\hline 1425 & 916.59 & 908.84 & & 889.75 & 882.04 \\
\hline 1430 & 916.59 & 908.84 & 898.81 & 889.94 & 882.13 \\
\hline 1435 & 916.59 & 908.84 & & 889.90 & 882.21 \\
\hline 1440 & 916.59 & 908.85 & 898.85 & 889.96 & 882.29 \\
\hline 1445 & 916.59 & 908.84 & & 890.03 & 882.38 \\
\hline 1450 & 916.59 & 908.85 & 898.88 & 890.09 & 882.46 \\
\hline 1455 & 916.59 & 908.85 & & 890.14 & 882.54 \\
\hline 1500 & 916.59 & 908.85 & 898.96 & 890.19 & 882.63 \\
\hline 1505 & 916.59 & 908.87 & & 890.24 & 882.70 \\
\hline 1510 & 916.59 & 908.85 & 898.95 & 890.29 & 882.78 \\
\hline 1515 & 916.58 & 908.86 & & 890.33 & 882.96 \\
\hline 1520 & 916.59 & 908.86 & 898.97 & 890.37 & 882.93 \\
\hline 1525 & 916.59 & 908.86 & & 890.41 & 882.99 \\
\hline 1530 & 916.59 & 908.87 & 899.00 & 890.45 & 883.06 \\
\hline 1535 & 916.59 & 908.87 & & 890.50 & 883.12 \\
\hline 1540 & 916.58 & 908.87 & 899.02 & 890.54 & 883.18 \\
\hline 1545 & 916.59 & 908.87 & & 890.57 & 883.24 \\
\hline 1550 & 916.59 & 908.88 & $\overline{899.0 \overline{3}}$ & 890.61 & 883.29 \\
\hline 1555 & 916.58 & 908.88 & & 890.64 & 883.34 \\
\hline 1600 & 916.59 & 908.88 & 899.08 & 890.68 & 883.40 \\
\hline 1605 & 916.59 & 908.88 & & 890.71 & 883.46 \\
\hline 1610 & 916.60 & 908.88 & 899.10 & 890.74 & 883.51 \\
\hline 1615 & 916.60 & 908.88 & & 890.76 & 883.55 \\
\hline 1620 & 916.60 & 908.89 & 899.09 & 890.78 & 883.60 \\
\hline 1625 & 916.60 & 908.89 & & 890.81 & 883.63 \\
\hline 1630 & 916.61 & 908.89 & 899.11 & 890.83 & 883.67 \\
\hline 1635 & 916.60 & 908.89 & - & 890.85 & 883.72 \\
\hline 1640 & 916.61 & 908.89 & 899.14 & 890.88 & 883.75 \\
\hline 1645 & 916.61 & 908.89 & & 890.90 & 883.80 \\
\hline 1650 & 916.61 & 908.90 & 899.15 & 890.92 & 883.83 \\
\hline 1655 & 916.64 & 908.90 & & 890.93 & 883.86 \\
\hline 1700 & 916.66 & 908.91 & 899.15 & 890.95 & 883.89 \\
\hline 1705 & 916.67 & 908.92 & & 890.97 & 883.93 \\
\hline 1710 & 916.68 & 908.92 & 899.17 & 890.99 & 883.95 \\
\hline 1715 & 916.68 & 908.93 & & 891.01 & 883.98 \\
\hline 1720 & 916.69 & 908.95 & 899.18 & 891.03 & 884.00 \\
\hline 1725 & 916.69 & 908.95 & & 891.04 & 884.04 \\
\hline 1730 & 916.69 & 908.95 & 899.18 & 891.06 & 884.06 \\
\hline 1735 & 916.70 & 908.96 & & 891.07 & 884.09 \\
\hline 1740 & 916.69 & 908.97 & 899.19 & 891.08 & 884.11 \\
\hline 1745 & 916.70 & 908.97 & & 891.09 & 884.14 \\
\hline 1750 & 916.69 & 908.98 & 899.19 & 891.11 & 884.16 \\
\hline 1755 & 916.68 & 908.99 & & 891.11 & 884.17 \\
\hline 1800 & 916.67 & 908.99 & 899.20 & 891.12 & 884.19 \\
\hline 1805 & 916.66 & 909.00 & & 891.13 & 884.21 \\
\hline 1810 & 916.66 & 909.00 & 899.15 & 891.14 & 884.22 \\
\hline 1815 & 916.66 & 908.99 & & 891.15 & 884.24 \\
\hline 1820 & 916.66 & 909.00 & $\overline{899.2 \overline{2}}$ & 981.16 & 884.26 \\
\hline 1825 & 916.66 & 909.00 & & 891.17 & 884.27 \\
\hline 1830 & 916.66 & 908.99 & 899.23 & 891.18 & 884.29 \\
\hline
\end{tabular}


TABLE 10.-Summary of river stage data-Continued

\begin{tabular}{|c|c|c|c|c|c|}
\hline \multirow[b]{2}{*}{$\begin{array}{l}\text { Date and } \\
\text { Time }\end{array}$} & \multicolumn{5}{|c|}{ Water-surface altitude, in feet } \\
\hline & $\begin{array}{l}\text { Buford } \\
\text { Dam }\end{array}$ & $\begin{array}{c}\text { Georgia } \\
\text { Highway } 20\end{array}$ & $\begin{array}{l}\text { Littles } \\
\text { Ferry } \\
\text { Bridge }\end{array}$ & $\begin{array}{c}\text { Georgia } \\
\text { Highway } 120\end{array}$ & $\begin{array}{c}\text { Georgia } \\
\text { Highway } 141\end{array}$ \\
\hline \multicolumn{6}{|l|}{ March 22, 1976: } \\
\hline 1835 & 916.66 & 909.00 & & 891.19 & 884.30 \\
\hline 1840 & 916.66 & 909.00 & 899.24 & 891.20 & 884.31 \\
\hline 1845 & 916.66 & 909.00 & & 891.20 & 884.33 \\
\hline 1850 & 916.66 & 908.99 & 899.25 & 891.21 & 884.34 \\
\hline 1855 & 916.65 & 909.00 & $-\ldots-$ & $-\ldots$ & 884.35 \\
\hline 1900 & 916.62 & 909.00 & 899.26 & $-\ldots-$ & 884.37 \\
\hline 1905 & 916.61 & 909.00 & & 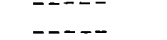 & 884.38 \\
\hline 1910 & 916.60 & 909.00 & 899.27 & ---- & 884.40 \\
\hline 1915 & 916.60 & 908.99 & & ---- & 884.41 \\
\hline 1920 & 916.59 & 908.98 & 899.29 & ---- & ----- \\
\hline 1925 & 916.59 & 908.98 & & ---- & \\
\hline 1930 & 916.59 & 908.97 & 899.29 & $\ldots$ & 884.48 \\
\hline 1935 & 916.59 & 908.97 & & ---- & --- \\
\hline 1940 & 916.59 & 908.96 & 899.31 & $\ldots$ & $-\ldots$ \\
\hline 1945 & 916.59 & 908.95 & & --- & - \\
\hline 1950 & 916.58 & 908.96 & 899.31 & ---- & ----- \\
\hline 1955 & 916.59 & 908.95 & & $-\ldots$ & ---- \\
\hline 2000 & 916.58 & 908.94 & 899.31 & ----- & ---- \\
\hline 2005 & 916.59 & 908.95 & & ---- & ---- \\
\hline 2010 & 916.59 & 908.94 & 899.30 & ----- & ----- \\
\hline 2015 & 916.59 & 908.94 & & 891.34 & - --- \\
\hline 2020 & 916.58 & 908.94 & 899.31 & - - - - & $\ldots-\ldots$ \\
\hline 2025 & 916.59 & 908.93 & & 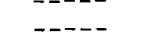 & ----- \\
\hline 2030 & 916.59 & 908.93 & 899.31 & --- & 884.57 \\
\hline 2035 & 916.59 & 908.93 & & --- & ----- \\
\hline 2040 & 916.58 & 908.92 & 899.32 & ---- & ----- \\
\hline 2045 & 916.58 & 908.92 & & ----- & $\ldots \ldots$ \\
\hline 2050 & 916.58 & 908.92 & 899.32 & --- & ----- \\
\hline 2055 & 916.58 & 908.92 & & & ----- \\
\hline 2100 & 916.59 & 908.91 & 899.31 & 891.34 & --- \\
\hline 2105 & 916.59 & 908.92 & & ----- & ----- \\
\hline 2110 & 916.59 & 908.92 & 899.31 & $-\ldots-$ & ---- \\
\hline 2115 & 916.59 & 908.91 & & $-\ldots$ & $-\ldots$ \\
\hline 2120 & 916.58 & 908.91 & 899.31 & $-0-1$ & - - - - \\
\hline 2125 & 916.58 & 908.91 & & 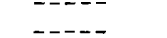 & \\
\hline 2130 & 916.59 & 908.91 & 899.31 & $-\ldots$ & 884.64 \\
\hline 2135 & 916.58 & 908.90 & & - - - - & -...- \\
\hline 2140 & 916.58 & 908.90 & 899.30 & ---- & ----- \\
\hline 2145 & 916.58 & 908.90 & & ----- & ---- \\
\hline 2150 & 916.41 & 908.90 & 899.30 & ----- & $-\ldots--$ \\
\hline 2155 & 915.60 & 908.89 & & $-\ldots-$ & - \\
\hline 2200 & 914.92 & 908.78 & 899.29 & $-\ldots-$ & $-\ldots$ \\
\hline 2205 & 914.44 & 908.61 & & ----- & $\ldots \ldots$ \\
\hline 2210 & 914.15 & 908.43 & 899.29 & 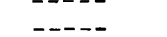 & $-\ldots$ \\
\hline 2215 & 913.94 & 908.26 & & 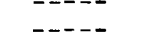 & - \\
\hline 2220 & 913.75 & 908.08 & $899.2 \overline{9}$ & - & 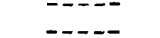 \\
\hline 2225 & 913.63 & 907.90 & - & $\begin{array}{l}----- \\
-----\end{array}$ & 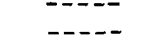 \\
\hline 2230 & 913.54 & 907.72 & 899.29 & - - - - & 884.68 \\
\hline 2235 & 913.49 & 907.54 & & $\ldots \ldots$ & $---\infty$ \\
\hline 2240 & 913.45 & 907.37 & 899.29 & ---- & - - - - \\
\hline 2245 & 913.42 & 907.20 & & $-\ldots--$ & $\ldots$ \\
\hline 2250 & 913.40 & 907.04 & 899.26 & ---- & 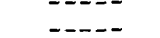 \\
\hline 2255 & 913.39 & 906.88 & & - --- & 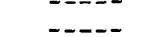 \\
\hline 2300 & 913.38 & 906.73 & 899.22 & 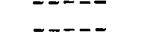 & - \\
\hline 2305 & 913.38 & 906.59 & & - & - - \\
\hline 2310 & 913.38 & 906.45 & 899.16 & ---- & 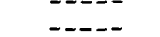 \\
\hline 2315 & 913.38 & 906.32 & $\ldots-\ldots$ & $\ldots$ & $-\ldots$ \\
\hline
\end{tabular}


TABLE 10.-Summary of river stage data-Continued

\begin{tabular}{|c|c|c|c|c|c|}
\hline \multirow[b]{2}{*}{$\begin{array}{l}\text { Date and } \\
\text { Time }\end{array}$} & \multicolumn{5}{|c|}{ Water-surface altitude, in feet } \\
\hline & $\begin{array}{l}\text { Buford } \\
\text { Dam }\end{array}$ & $\begin{array}{c}\text { Georgia } \\
\text { Highway } 20\end{array}$ & $\begin{array}{l}\text { Littles } \\
\text { Ferry } \\
\text { Bridge }\end{array}$ & $\begin{array}{c}\text { Georgia } \\
\text { Highway } 120\end{array}$ & $\begin{array}{c}\text { Georgia } \\
\text { Highway } 14\end{array}$ \\
\hline \multicolumn{6}{|l|}{ March 22, 1976: } \\
\hline 2320 & 913.38 & 906.19 & 899.11 & 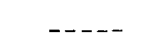 & ---- \\
\hline 2325 & 913.38 & 906.07 & & & \\
\hline 2330 & 913.38 & 905.94 & 899.01 & --- & 884.70 \\
\hline 2335 & 913.38 & 905.82 & & $\ldots$ & -..-- \\
\hline 2340 & 913.38 & 905.71 & 898.88 & $-\ldots-$ & --- \\
\hline 2345 & 913.38 & 905.60 & & & ---- \\
\hline 2350 & 913.38 & 905.50 & 898.75 & $-\cdots$ & 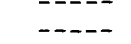 \\
\hline 2355 & 913.38 & 905.39 & $-\ldots-$ & $\ldots-$ & ---- \\
\hline \multicolumn{6}{|c|}{$\begin{array}{cc}\text { March 23, 1976: } & \\
0000 & 913.38\end{array}$} \\
\hline 0000 & $\begin{array}{l}913.38 \\
913.38\end{array}$ & $\begin{array}{l}905.29 \\
905.19\end{array}$ & 898.63 & 891.20 & ---- \\
\hline $\begin{array}{l}0005 \\
0010\end{array}$ & $\begin{array}{l}913.38 \\
913.38\end{array}$ & $\begin{array}{l}905.19 \\
905.10\end{array}$ & 898.48 & ---- & ---- \\
\hline $\begin{array}{l}0010 \\
0015\end{array}$ & 913.38 & 905.01 & & 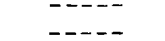 & $\begin{array}{l}---- \\
----\end{array}$ \\
\hline 0020 & 913.38 & 904.93 & 898.34 & ---- & $-\cdots$ \\
\hline 0025 & 913.38 & 904.84 & & & \\
\hline 0030 & 913.38 & 904.76 & 898.20 & -..-- & 884.67 \\
\hline 0035 & 913.38 & 904.69 & & ---- & $\ldots$ \\
\hline 0040 & 913.38 & 904.61 & 898.03 & $-\ldots$ & $-\cdots$ \\
\hline 0045 & 913.38 & 904.54 & & -...- & ---- \\
\hline 0050 & 913.38 & 904.47 & 897.88 & --- & --- \\
\hline 0055 & 913.38 & 904.41 & & $\ldots$ & -.-- \\
\hline 0100 & 913.38 & 904.34 & 897.72 & $\ldots-$ & $\ldots$ \\
\hline 0105 & 913.38 & 904.28 & & $-\ldots$ & --- \\
\hline 0110 & 913.38 & 904.22 & 897.56 & ---- & ---- \\
\hline 0115 & 913.38 & 904.17 & & ---- & --- \\
\hline 0120 & 913.38 & 904.11 & 897.41 & ---- & $-\ldots$ \\
\hline 0125 & 913.38 & 904.06 & & & \\
\hline 0130 & 913.38 & 904.01 & 897.26 & 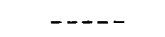 & 884.56 \\
\hline 0135 & 913.38 & 903.96 & & ---- & --- \\
\hline 0140 & 913.38 & 903.91 & 897.10 & $-\cdots$ & ---- \\
\hline 0145 & 913.38 & 903.87 & 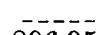 & ---- & -..- \\
\hline 0150 & 913.38 & 903.83 & 896.95 & ---- &.--- \\
\hline 0155 & 913.38 & 903.79 & 89680 & ---- & -.-- \\
\hline 0200 & 913.38 & 903.75 & 896.80 & --- & ---- \\
\hline 0205 & 913.38 & 903.72 & 896.64 & -..- & 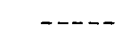 \\
\hline 0210 & 913.38 & 903.69 & & $\ldots-$ & $-\ldots$ \\
\hline 0215 & 913.38 & 903.65 & 896.51 & ---- &.--- \\
\hline 0220 & 913.38 & 903.62 & & ---- & ---- \\
\hline $\begin{array}{l}0225 \\
0230\end{array}$ & $\begin{array}{l}913.38 \\
913.38\end{array}$ & $\begin{array}{l}903.59 \\
903.56\end{array}$ & $\overline{896.36}$ & $-\cdots$ & 884.29 \\
\hline 0235 & 913.38 & 903.54 & & $\begin{array}{ll}--n-1 \\
-n-1\end{array}$ & 004.28 \\
\hline 0240 & 913.38 & 903.52 & 896.22 & -...- & $-\ldots$ \\
\hline 0245 & 913.38 & 903.49 & & & \\
\hline 0250 & 913.38 & 903.47 & 896.10 & $\ldots$ & -... \\
\hline 0255 & 913.38 & 903.45 & & & \\
\hline 0300 & 913.38 & 903.43 & 895.96 &.--- & $-\ldots$ \\
\hline 0305 & 913.38 & 903.41 & & --- & ---- \\
\hline 0310 & 913.38 & 903.39 & 895.88 & $-\cdots-$ & --- \\
\hline 0315 & 913.38 & 903.37 & 89581 & $-\cdots$ & $\ldots$ \\
\hline 0320 & 913.38 & 903.36 & 895.81 & --- & $-\cdots$ \\
\hline $\begin{array}{l}0325 \\
0330\end{array}$ & $\begin{array}{l}913.38 \\
913.38\end{array}$ & $\begin{array}{l}903.34 \\
903.33\end{array}$ & $\overline{895.61}$ & $-\cdots$ & $\overline{883.8 \overline{8}}$ \\
\hline 0335 & 913.38 & 903.31 & & 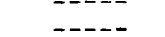 & 000.00 \\
\hline 0340 & 913.38 & 903.30 & 895.34 & -..-- & -.... \\
\hline 0345 & 913.38 & 903.29 & & --- & -..- \\
\hline 0350 & 913.38 & 903.27 & 895.21 & $-\cdots-$ & --- \\
\hline
\end{tabular}


TABLE 10.-Summary of river stage data-Continued

\begin{tabular}{|c|c|c|c|c|c|}
\hline \multirow[b]{2}{*}{$\begin{array}{c}\text { Date and } \\
\text { Time }\end{array}$} & \multicolumn{5}{|c|}{ Water-surface altitude, in feet } \\
\hline & $\begin{array}{c}\text { Buford } \\
\text { Dam }\end{array}$ & $\begin{array}{c}\text { Georgia } \\
\text { Highway } 20\end{array}$ & $\begin{array}{l}\text { Littles } \\
\text { Ferry } \\
\text { Bridge }\end{array}$ & $\begin{array}{c}\text { Georgia } \\
\text { Highway } 120\end{array}$ & $\begin{array}{c}\text { Georgia } \\
\text { Highway } 141\end{array}$ \\
\hline \multicolumn{6}{|c|}{ March 23, 1976: } \\
\hline 0355 & 913.38 & 903.26 & ---- & ---- & ---- \\
\hline 0400 & 913.38 & 903.25 & ----- & ----- & ---- \\
\hline 0405 & 913.38 & 903.24 & & ----- & ----- \\
\hline 0410 & 913.38 & 903.23 & 895.07 & ----- & ---- \\
\hline 0415 & 913.38 & 903.22 & & $\begin{array}{ll}----- \\
--n-1\end{array}$ & ----- \\
\hline 0420 & 913.38 & 903.21 & 895.07 & ----- & ---- \\
\hline 0425 & 913.38 & 903.20 & & $-\ldots-$ & \\
\hline 0430 & 913.38 & 903.20 & 894.81 & --- & 883.43 \\
\hline 0435 & 913.38 & 903.19 & & ----- & ----- \\
\hline 0440 & 913.38 & 903.18 & 894.66 & $\ldots-\ldots$ & $-\ldots-$ \\
\hline 0445 & 913.38 & 903.17 & & ----- & ----- \\
\hline 0450 & 913.38 & 903.17 & 894.61 & $\ldots$ & ----- \\
\hline 0455 & 913.38 & 903.16 & & $-\ldots$ & ---- \\
\hline 0500 & 913.38 & 903.15 & 894.59 & 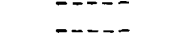 & $\begin{array}{l}---0- \\
-\cdots--\end{array}$ \\
\hline 0505 & 913.38 & 903.15 & & ----1 & - \\
\hline 0510 & 913.38 & 903.14 & 894.56 & - & 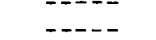 \\
\hline 0515 & 913.38 & 903.14 & & - & ----- \\
\hline 0520 & 913.38 & 903.13 & 894.57 & $\ldots$ & $\ldots-$ \\
\hline 0525 & 913.38 & 903.13 & & ----- & ----- \\
\hline 0530 & 913.38 & 903.12 & 894.41 & --- & 882.97 \\
\hline 0535 & 913.38 & 903.12 & &.-- & 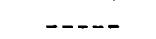 \\
\hline 0540 & 913.38 & 903.11 & 894.32 & ----- & $\ldots-\ldots$ \\
\hline 0545 & 913.38 & 903.11 & & ----- & ---- \\
\hline 0550 & 913.38 & 903.11 & 894.20 & ---- & ---- \\
\hline 0555 & 913.38 & 903.10 & & ----- & ---- \\
\hline 0600 & 913.38 & 903.10 & 894.17 & $-\ldots--$ & ---- \\
\hline 0605 & 913.38 & 903.09 & - & ----- &.--- \\
\hline 0610 & 913.38 & 903.09 & $-\ldots-$ & $-\ldots$ & ---- \\
\hline 0615 & 913.38 & 903.09 & ---- & ---- & ---- \\
\hline 0620 & 913.38 & 903.08 & 894.06 & -..-- &.-- \\
\hline 0625 & 913.38 & 903.08 & & ----- & ----- \\
\hline 0630 & 913.38 & 903.08 & 894.00 & --- & 882.51 \\
\hline 0635 & 913.38 & 903.08 & ----- & ---- & $-\cdots-$ \\
\hline 0640 & 913.38 & 903.07 & 893.96 & --- & --- \\
\hline 0645 & 913.38 & 903.07 & & --- & $-\cdots$ \\
\hline 0650 & 913.38 & 903.07 & 893.87 & ---- &.--- \\
\hline 0655 & 914.03 & 903.07 & & $\ldots-\ldots$ & ---- \\
\hline 0700 & 915.93 & 903.06 & 893.88 & --- & --- \\
\hline 0705 & 917.36 & 903.06 & &.---- & -..- \\
\hline 0710 & 918.17 & 903.11 & 893.81 & $\ldots \ldots$ & $-\ldots$ \\
\hline 0715 & 918.51 & 903.69 & & --- & $-\ldots-$ \\
\hline 0720 & 918.66 & 904.69 & 893.80 & ---- & $-\ldots$ \\
\hline 0725 & 918.76 & 905.73 & & $-\ldots$ & 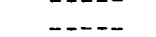 \\
\hline 0730 & 918.83 & 906.50 & 893.76 & 886.75 & 882.09 \\
\hline 0735 & 918.87 & 907.12 & & ----- & ---- \\
\hline 0740 & 918.91 & 907.70 & 893.69 & ---- & ---- \\
\hline 0745 & 918.94 & 908.60 & & ---- & ----- \\
\hline 0750 & 918.96 & 908.60 & 893.66 & ---- & ---- \\
\hline 0755 & 918.99 & 908.92 & --- & ---- & ---- \\
\hline 0800 & 919.01 & 909.22 &.---- & $-\ldots$ & $\ldots$ \\
\hline 0805 & 919.03 & 909.51 & ---- & ---- & $\ldots$ \\
\hline 0810 & 919.05 & 909.79 & 893.61 & 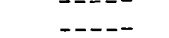 & 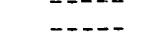 \\
\hline 0815 & 919.08 & 910.01 & & - & ---- \\
\hline 0820 & 919.09 & 910.19 & 893.57 & ----- & ---- \\
\hline 0825 & 919.12 & 910.38 & ---- & ----- & $\ddot{-r-n}$ \\
\hline 0830 & 919.14 & 910.55 & ---- & ----- & 881.71 \\
\hline
\end{tabular}


TABLE 10.-Summary of river stage data-Continued

\begin{tabular}{|c|c|c|c|c|c|}
\hline \multirow{2}{*}{$\begin{array}{c}\text { Date and } \\
\text { Time }\end{array}$} & \multicolumn{5}{|c|}{ Water-surface altitude, in feet } \\
\hline & $\begin{array}{c}\text { Buford } \\
\text { Dam }\end{array}$ & $\begin{array}{c}\text { Georgia } \\
\text { Highway } 20\end{array}$ & $\begin{array}{l}\text { Littles } \\
\text { Ferry } \\
\text { Bridge }\end{array}$ & $\begin{array}{c}\text { Georgia } \\
\text { Highway } 120\end{array}$ & $\begin{array}{c}\text { Georgia } \\
\text { Highway } 141\end{array}$ \\
\hline \multicolumn{6}{|c|}{ March 23, 1976: } \\
\hline 0835 & 919.15 & 910.74 & & ---- & ---- \\
\hline 0840 & 919.17 & 910.90 & 893.57 & ---- & ----- \\
\hline 0845 & 919.19 & 911.01 & & ----- & ----- \\
\hline 0850 & 919.20 & 911.09 & 893.56 & ---- & ----- \\
\hline 0855 & 919.23 & 911.26 & & $-\ldots--$ & ----- \\
\hline 0900 & 919.24 & 911.38 & 893.71 & 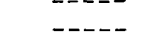 & ----- \\
\hline 0905 & 919.25 & 911.49 & & $--\ldots--$ & ----2 \\
\hline 0910 & 919.28 & 911.60 & 894.09 & ---- & ---- \\
\hline 0915 & 919.29 & 911.70 & & ----- & ----- \\
\hline 0920 & 919.30 & 911.77 & 894.61 & - & ----- \\
\hline 0925 & 919.32 & 911.87 & & ----- & \\
\hline 0930 & 919.34 & 911.97 & 895.23 & & 881.38 \\
\hline 0935 & 919.35 & 912.04 & & 886.01 & -- - - \\
\hline 0940 & 919.37 & 912.12 & 896.15 & 885.99 & $--\ldots$ \\
\hline 0945 & 919.38 & 912.17 & & 885.97 & $-0-1$ \\
\hline 0950 & 919.40 & 912.22 & 896.82 & 885.96 & ---- \\
\hline 0955 & 919.42 & 912.30 & & 885.95 & ----- \\
\hline 1000 & 919.43 & 912.37 & 897.63 & 885.95 & $--\ldots$ \\
\hline 1005 & 919.44 & 912.43 & & 885.91 & ----- \\
\hline 1010 & 919.45 & 912.48 & 898.01 & 885.87 & $-\ldots--$ \\
\hline 1015 & 919.46 & 912.51 & & 885.99 & -.--- \\
\hline 1020 & 919.47 & 912.58 & 898.79 & 886.11 & $-\ldots--$ \\
\hline 1025 & 919.49 & 912.63 & & 886.23 & $-\ldots--$ \\
\hline 1030 & 919.51 & 912.67 & 899.17 & 886.35 & 881.14 \\
\hline 1035 & 919.50 & 912.71 & & 886.51 & \\
\hline 1040 & 919.52 & 912.74 & 899.60 & 886.67 & 880.97 \\
\hline 1045 & 919.53 & 912.79 & & 887.01 & 880.98 \\
\hline 1050 & 919.54 & 912.80 & 900.10 & 887.34 & 881.00 \\
\hline 1055 & 919.55 & 912.86 & & 887.47 & 881.01 \\
\hline 1100 & 919.57 & 912.90 & 900.33 & 887.60 & 881.02 \\
\hline 1105 & 919.57 & 912.92 & & 887.87 & 881.01 \\
\hline 1110 & 919.59 & 912.94 & 900.69 & 888.15 & 881.01 \\
\hline 1115 & 919.57 & 912.98 & & 888.42 & 881.01 \\
\hline 1120 & 919.55 & 912.99 & 900.94 & 888.70 & 881.02 \\
\hline 1125 & 919.55 & 913.03 & & 888.96 & 881.04 \\
\hline 1130 & 919.54 & 913.04 & 901.20 & 889.22 & 881.07 \\
\hline 1135 & 919.55 & 913.06 & & 889.48 & 881.09 \\
\hline 1140 & 919.55 & 913.07 & 901.38 & 889.74 & 881.15 \\
\hline 1145 & 919.55 & 913.08 & & 890.00 & 881.21 \\
\hline 1150 & 919.25 & 913.09 & 901.56 & 890.26 & 881.27 \\
\hline 1155 & 918.40 & 913.02 & & 890.45 & 881.36 \\
\hline 1200 & 917.32 & 912.75 & 901.77 & 890.65 & 881.46 \\
\hline 1205 & 916.50 & 912.41 & & 890.87 & 881.58 \\
\hline 1210 & 915.91 & 912.09 & 901.93 & 981.10 & 881.71 \\
\hline 1215 & 915.46 & 911.80 & & 891.25 & 881.85 \\
\hline 1220 & 915.10 & 911.50 & 902.03 & 891.41 & 882.00 \\
\hline 1225 & 914.80 & 911.23 & & 891.59 & 882.15 \\
\hline 1230 & 914.55 & 911.97 & 902.20 & 891.77 & 882.32 \\
\hline 1235 & 914.34 & 910.71 & & 891.95 & 882.49 \\
\hline 1240 & 914.15 & 910.47 & 902.26 & 892.13 & 882.66 \\
\hline 1245 & 913.99 & 910.23 & & 892.25 & 882.82 \\
\hline 1250 & 913.86 & 910.00 & 902.26 & 892.37 & 882.99 \\
\hline 1255 & 913.74 & 909.78 & & 892.51 & 883.17 \\
\hline 1300 & 913.65 & 909.57 & 902.21 & 892.65 & 883.32 \\
\hline 1305 & 913.58 & 909.36 & & 892.75 & 883.51 \\
\hline 1310 & 913.53 & 909.16 & 902.15 & 892.85 & 883.68 \\
\hline 1315 & 913.49 & 908.97 & - . - - & 892.93 & 883.83 \\
\hline
\end{tabular}


TABLE 10.-Summary of river stage data-Continued

\begin{tabular}{|c|c|c|c|c|c|}
\hline \multirow[b]{2}{*}{$\begin{array}{l}\text { Date and } \\
\text { Time }\end{array}$} & \multicolumn{5}{|c|}{ Water-surface altitude, in feet } \\
\hline & $\begin{array}{l}\text { Buford } \\
\text { Dam }\end{array}$ & $\begin{array}{c}\text { Georgia } \\
\text { Highway } 20\end{array}$ & $\begin{array}{l}\text { Littles } \\
\text { Ferry } \\
\text { Bridge }\end{array}$ & $\begin{array}{c}\text { Georgia } \\
\text { Highway } 120\end{array}$ & $\begin{array}{c}\text { Georgia } \\
\text { Highway } 141\end{array}$ \\
\hline \multicolumn{6}{|l|}{ March 23, 1976 : } \\
\hline 1320 & 913.46 & 908.77 & 902.01 & 893.02 & 884.00 \\
\hline 1325 & 913.43 & 908.59 & & 893.09 & 884.14 \\
\hline 1330 & 913.42 & 908.40 & $901.8 \overline{7}$ & 893.17 & 884.31 \\
\hline 1335 & 913.41 & 908.22 & & 893.24 & 884.43 \\
\hline 1340 & 913.40 & 908.05 & $901 . \overline{7}$ & 893.31 & 884.57 \\
\hline 1345 & 913.40 & 907.89 & & 893.35 & 884.71 \\
\hline 1350 & 913.40 & 907.72 & $901.5 \overline{3}$ & 893.39 & 884.83 \\
\hline 1355 & 913.39 & 907.56 & & 893.42 & 884.96 \\
\hline 1400 & 913.39 & 907.41 & 901.36 & 893.45 & 885.06 \\
\hline 1405 & 913.39 & 907.26 & & 893.46 & 885.16 \\
\hline 1410 & 913.38 & 907.11 & 901.11 & 893.48 & 885.27 \\
\hline 1415 & 913.38 & 906.97 & & 893.48 & 885.35 \\
\hline 1420 & 913.38 & 906.83 & 900.91 & 893.49 & 885.44 \\
\hline 1425 & 913.38 & 906.70 & & 893.47 & 885.52 \\
\hline 1430 & 913.38 & 906.56 & 900.68 & 893.45 & 885.60 \\
\hline 1435 & 913.38 & 906.44 & & 893.41 & 885.66 \\
\hline 1440 & 913.38 & 906.32 & 900.48 & 893.38 & 885.71 \\
\hline 1445 & 913.38 & 906.20 & & 893.35 & 885.76 \\
\hline 1450 & 913.38 & 906.08 & $900 . \overline{2} \overline{7}$ & 893.32 & 885.81 \\
\hline 1455 & 913.38 & 905.98 & & 893.27 & 885.84 \\
\hline 1500 & 913.38 & 905.86 & $900.0 \overline{7}$ & 893.23 & 885.87 \\
\hline 1505 & 913.38 & 905.76 & & 893.19 & 885.90 \\
\hline 1510 & 913.38 & 905.65 & 899.73 & 893.15 & 885.92 \\
\hline 1515 & 913.38 & 905.55 & & 893.09 & 885.93 \\
\hline 1520 & 913.38 & 905.45 & 899.55 & 893.03 & 885.95 \\
\hline 1525 & 913.38 & 905.37 & & 892.96 & 885.96 \\
\hline 1530 & 913.38 & 905.27 & 899.32 & 892.90 & 885.96 \\
\hline 1535 & 913.38 & 905.18 & & 892.84 & 885.95 \\
\hline 1540 & 913.38 & 905.08 & 899.15 & 892.79 & 885.95 \\
\hline 1545 & 913.38 & 905.00 & & 892.71 & 885.94 \\
\hline 1550 & 913.38 & 904.90 & 898.93 & 892.64 & 885.92 \\
\hline 1555 & 913.38 & 904.84 & & 892.55 & 885.91 \\
\hline 1600 & 913.38 & 904.74 & 898.75 & 892.47 & 885.89 \\
\hline 1605 & 913.38 & 904.70 & & 892.39 & 885.87 \\
\hline 1610 & 913.38 & 904.60 & 898.46 & 892.32 & 885.84 \\
\hline 1615 & 913.38 & 904.58 & & 892.24 & 885.84 \\
\hline 1620 & 913.38 & 904.50 & 898.25 & 892.15 & 885.83 \\
\hline 1625 & 913.38 & 904.44 & & 892.07 & 885.83 \\
\hline 1630 & 913.38 & 904.38 & 898.07 & 891.99 & 885.82 \\
\hline 1635 & 913.38 & 904.32 & & 891.91 & 885.78 \\
\hline 1640 & 913.38 & 904.26 & 897.90 & 891.83 & 885.74 \\
\hline 1645 & 913.38 & 904.20 & & 891.75 & 885.70 \\
\hline 1650 & 913.38 & 904.16 & 897.81 & 891.65 & 885.66 \\
\hline 1655 & 913.38 & 904.10 & & 891.57 & 885.62 \\
\hline 1700 & 913.38 & 904.05 & 897.52 & 891.50 & 885.57 \\
\hline 1705 & 913.38 & 904.00 & & 891.42 & 885.53 \\
\hline 1710 & 913.38 & 903.96 & 897.35 & 891.34 & 885.49 \\
\hline 1715 & 913.38 & 903.92 & & 891.24 & 885.45 \\
\hline 1720 & 913.38 & 903.86 & 897.13 & 891.15 & 885.41 \\
\hline 1725 & 913.38 & 903.83 & & 891.07 & 885.37 \\
\hline 1730 & 913.38 & 903.79 & 897.00 & 890.98 & 885.34 \\
\hline 1735 & 913.38 & 903.74 & & 890.90 & 885.29 \\
\hline 1740 & 913.38 & 903.71 & $896 . \overline{84}$ & 890.81 & 885.24 \\
\hline 1745 & 913.38 & 903.68 & & 890.73 & 885.19 \\
\hline 1750 & 913.38 & 903.65 & 896.65 & 890.64 & 885.14 \\
\hline 1755 & 913.38 & 903.61 & & 890.56 & 885.09 \\
\hline 1800 & 913.38 & 903.59 & 896.50 & 890.45 & 885.03 \\
\hline
\end{tabular}


TABLE 10.-Summary of river stage data-Continued

\begin{tabular}{|c|c|c|c|c|c|}
\hline \multirow[b]{2}{*}{$\begin{array}{l}\text { Date and } \\
\text { Time }\end{array}$} & \multicolumn{5}{|c|}{ Water-surface altitude, in feet } \\
\hline & $\begin{array}{l}\text { Buford } \\
\text { Dam }\end{array}$ & $\begin{array}{c}\text { Georgia } \\
\text { Highway } 20\end{array}$ & $\begin{array}{c}\text { Littles } \\
\text { Ferry } \\
\text { Bridge }\end{array}$ & $\begin{array}{c}\text { Georgia } \\
\text { Highway } 120\end{array}$ & $\begin{array}{c}\text { Georgia } \\
\text { Highway } 141\end{array}$ \\
\hline \multicolumn{6}{|c|}{ March 23, 1976: } \\
\hline 1805 & 913.38 & 903.56 & & 890.38 & 884.98 \\
\hline 1810 & 913.38 & 903.53 & 896.34 & 890.30 & 884.93 \\
\hline 1815 & 913.38 & 903.51 & & 890.23 & 884.88 \\
\hline 1820 & 913.38 & 903.49 & 896.21 & 890.13 & 884.83 \\
\hline 1825 & 913.38 & 903.46 & & 890.03 & 884.78 \\
\hline 1830 & 913.38 & 903.44 & 895.94 & 889.94 & 884.73 \\
\hline 1835 & 913.38 & 903.42 & & 889.87 & 884.67 \\
\hline 1840 & 913.38 & 903.41 & 895.91 & 889.80 & 884.61 \\
\hline 1845 & 913.38 & 903.39 & & 889.72 & 884.55 \\
\hline 1850 & 913.38 & 903.37 & 895.76 & 889.65 & 884.49 \\
\hline 1855 & 913.38 & 903.36 & & 889.56 & 884.43 \\
\hline 1900 & 913.38 & 903.34 & 895.64 & 889.47 & 884.37 \\
\hline 1905 & 913.38 & 903.33 & & 889.40 & 884.31 \\
\hline 1910 & 913.38 & 903.31 & 895.49 & 889.34 & 884.25 \\
\hline 1915 & 913.38 & 903.30 & & 889.27 & 884.19 \\
\hline 1920 & 913.38 & 903.29 & 895.39 & 889.18 & 884.13 \\
\hline 1925 & 913.38 & 903.28 & & 889.11 & 884.08 \\
\hline 1930 & 913.38 & 903.27 & 895.26 & 889.04 & 884.03 \\
\hline 1935 & 913.38 & 903.26 & & 888.97 & 883.97 \\
\hline 1940 & 913.38 & 903.25 & 895.13 & 888.89 & 883.92 \\
\hline 1945 & 913.38 & 903.24 & & 888.81 & 883.86 \\
\hline 1950 & 913.38 & 902.23 & 895.02 & 888.74 & 883.81 \\
\hline 1955 & 913.38 & 903.22 & & 888.67 & 883.76 \\
\hline 2000 & 913.38 & 903.21 & 894.93 & 888.60 & 883.70 \\
\hline 2005 & 913.38 & 903.20 & & 888.53 & 883.64 \\
\hline 2010 & 913.38 & 903.20 & 894.83 & 888.46 & 883.59 \\
\hline 2015 & 913.38 & 903.19 & & 888.39 & 883.54 \\
\hline 2020 & 913.38 & 903.18 & 894.73 & 888.34 & 883.49 \\
\hline 2025 & 913.38 & 903.18 & & 888.26 & 883.43 \\
\hline 2030 & 913.38 & 903.17 & 894.63 & 888.22 & 883.36 \\
\hline 2035 & 913.38 & 903.17 & & 888.16 & 883.31 \\
\hline 2040 & 913.38 & 903.16 & 894.56 & 888.10 & 883.26 \\
\hline 2045 & 913.38 & 903.16 & & 888.03 & 883.21 \\
\hline 2050 & 913.38 & 903.15 & 894.48 & 887.96 & 883.16 \\
\hline 2055 & 913.38 & 903.15 & & 887.90 & 883.11 \\
\hline 2100 & 913.38 & 903.14 & 894.39 & 887.84 & 883.06 \\
\hline 2105 & 913.38 & 903.14 & & 887.79 & 883.01 \\
\hline 2110 & 913.38 & 903.13 & 894.31 & 887.74 & 882.96 \\
\hline 2115 & 913.38 & 903.13 & & 887.66 & 882.91 \\
\hline 2120 & 913.38 & 903.13 & $8 \overline{4} . \overline{2}$ & 887.59 & 882.86 \\
\hline 2125 & 913.38 & 903.12 & & 887.53 & 882.83 \\
\hline 2130 & 913.38 & 902.12 & 894.17 & 887.48 & 882.79 \\
\hline 2135 & 913.38 & 902.12 & & 887.42 & 882.75 \\
\hline 2140 & 913.38 & 903.11 & 894.11 & 887.36 & 882.71 \\
\hline 2145 & 913.38 & 903.11 & & 887.32 & 882.67 \\
\hline 2150 & 913.38 & 903.11 & 894.05 & 887.28 & 882.63 \\
\hline 2155 & 913.38 & 903.10 & & 887.23 & 882.59 \\
\hline 2200 & 913.38 & 903.10 & 893.99 & 887.17 & 882.55 \\
\hline 2205 & 913.38 & 903.10 & & 887.12 & 882.51 \\
\hline 2210 & 913.38 & 903.10 & 893.93 & 887.07 & 882.47 \\
\hline 2215 & 913.38 & 903.09 & - & 887.02 & 882.43 \\
\hline 2220 & 913.38 & 903.09 & 893.99 & 886.98 & 882.39 \\
\hline 2225 & 913.38 & 903.09 & & 886.92 & 882.35 \\
\hline 2230 & 913.38 & 903.09 & $\overline{893.83}$ & 886.87 & 882.29 \\
\hline 2235 & 913.38 & 903.08 & & 886.85 & 882.26 \\
\hline 2240 & 913.38 & 903.08 & 893.79 & 886.83 & 882.23 \\
\hline 2245 & 913.38 & 903.08 & _. & 886.78 & 882.20 \\
\hline
\end{tabular}


TABLE 10.-Summary of river stage data-Continued

\begin{tabular}{|c|c|c|c|c|c|}
\hline \multirow[b]{2}{*}{$\begin{array}{c}\text { Date and } \\
\text { Time }\end{array}$} & \multicolumn{5}{|c|}{ Water-surface altitude, in feet } \\
\hline & $\begin{array}{c}\text { Buford } \\
\text { Dam }\end{array}$ & $\begin{array}{c}\text { Georgia } \\
\text { Highway } 20\end{array}$ & $\begin{array}{c}\text { Littles } \\
\text { Ferry } \\
\text { Bridge }\end{array}$ & $\underset{\text { Georgia }}{\text { Highway } 120}$ & $\begin{array}{c}\text { Highway } 141 \\
\text { Georgia }\end{array}$ \\
\hline \multicolumn{6}{|c|}{ March 23, 1976: } \\
\hline 2250 & 913.38 & 903.08 & 893.74 & 886.73 & 882.17 \\
\hline 2255 & 913.38 & 903.07 & & 886.70 & 882.14 \\
\hline 2300 & 913.38 & 903.07 & 893.70 & 886.67 & 882.11 \\
\hline 2305 & 913.38 & 903.07 & & 886.61 & 882.08 \\
\hline 2310 & 913.38 & 903.07 & 893.66 & 886.56 & 882.06 \\
\hline 2315 & 913.38 & 903.07 & & 886.53 & 882.03 \\
\hline 2320 & 913.38 & 903.06 & 893.62 & 886.51 & 881.98 \\
\hline 2325 & 913.38 & 903.06 & & 886.48 & 881.92 \\
\hline 2330 & 913.38 & 903.06 & 893.60 & 886.43 & 881.86 \\
\hline 2335 & 913.38 & 903.06 & & 886.39 & 881.83 \\
\hline 2340 & 913.38 & 903.06 & 893.56 & 886.36 & 881.81 \\
\hline 2345 & 913.38 & 903.06 & & 886.33 & 881.78 \\
\hline 2350 & 913.38 & 903.06 & 893.53 & 886.30 & 881.75 \\
\hline 2355 & 913.38 & 903.06 & -.-- & 886.28 & 881.72 \\
\hline
\end{tabular}

TABLE 11.-Summary of river discharge data

\begin{tabular}{|c|c|c|c|c|}
\hline \multirow[b]{2}{*}{$\begin{array}{l}\text { Date and } \\
\text { Time }\end{array}$} & \multicolumn{4}{|c|}{ Discharge, in $\mathrm{ft}^{3} / \mathrm{s}$} \\
\hline & $\begin{array}{c}\text { Georgia } \\
\text { Highway } 20\end{array}$ & $\begin{array}{c}\text { Littles } \\
\text { Ferry Bridge }\end{array}$ & $\begin{array}{c}\text { Georgia } \\
\text { Highway } 120\end{array}$ & $\begin{array}{c}\text { Georgia } \\
\text { Highway } 141\end{array}$ \\
\hline \multicolumn{5}{|l|}{ March 22, 1976: } \\
\hline 0655 & 577 & ---- & ---- & ---- \\
\hline 0700 & 577 & --- & --- & $\ldots$ \\
\hline 0705 & 577 & --- & --- & --- \\
\hline 0710 & 577 & --- & -.-- & -.-- \\
\hline 0715 & 610 & -..- & ---- & $-\ldots$ \\
\hline 0720 & 610 & $\ldots$ & -.-- & -..- \\
\hline 0725 & 780 & $-\ldots$ & $\ldots$ & $-\ldots$ \\
\hline 0730 & 1030 & $\ldots$ & ---- & -.-- \\
\hline 0735 & 1280 & --- & --- & ---- \\
\hline 0740 & 1550 & --- & -- & -..- \\
\hline 0745 & 1820 & $\ldots$ & -..- & $\ldots$ \\
\hline 0750 & 2070 & & --- & ---- \\
\hline 0755 & 2360 & 600 & -..- & - \\
\hline 0800 & 2620 & 600 & --- & --- \\
\hline 0805 & 2830 & 600 & -..- & -..- \\
\hline 0810 & 2980 & 600 & -... & -.-- \\
\hline 0815 & 3110 & 600 & -..- & $\ldots$ \\
\hline 0820 & 3200 & 600 & $\ldots$ & - \\
\hline 0825 & 3290 & 600 & -..- & $\ldots$ \\
\hline 0830 & 3370 & 600 & $\ldots$ & -..- \\
\hline 0835 & 3450 & 600 & $\ldots$ & $\ldots$ \\
\hline 0840 & 3490 & 600 & $\ldots$ & $\ldots$ \\
\hline 0845 & 3530 & 600 & -... & $\ldots$ \\
\hline 0850 & 3560 & 600 & -... & $\ldots$ \\
\hline 0855 & 3590 & 610 & -.. & $\ldots$ \\
\hline 0900 & 3630 & 620 & $\ldots$ & $\ldots$ \\
\hline 0905 & 3670 & 730 & 931 & -..- \\
\hline 0910 & 3700 & 810 & 933 & - \\
\hline 0915 & 3740 & 860 & 933 & - - \\
\hline 0920 & 3770 & 940 & 934 & - \\
\hline 0925 & 3810 & 1080 & 936 & - - \\
\hline 0930 & 3830 & 1160 & 938 & - - \\
\hline
\end{tabular}


TABLE 11.-Summary of river discharge data-Continued

\begin{tabular}{|c|c|c|c|c|}
\hline \multirow[b]{2}{*}{$\begin{array}{l}\text { Date and } \\
\text { Time }\end{array}$} & \multicolumn{4}{|c|}{ Discharge, in $\mathrm{ft}^{3} / \mathrm{s}$} \\
\hline & $\begin{array}{c}\text { Georgia } \\
\text { Highway 20 }\end{array}$ & $\begin{array}{c}\text { Littles } \\
\text { Ferry Bridge }\end{array}$ & $\begin{array}{c}\text { Georgia } \\
\text { Highway } 120\end{array}$ & $\begin{array}{c}\text { Georgia } \\
\text { Highway } 14\end{array}$ \\
\hline \multicolumn{5}{|l|}{ March 22, 1976: } \\
\hline 0935 & 3840 & 1250 & 939 & $-\ldots$ \\
\hline 0940 & 3830 & 1340 & 940 & $\ldots$ \\
\hline 0945 & 3760 & 1440 & 943 & -..- \\
\hline 0950 & 3780 & 1520 & 945 & $\ldots$ \\
\hline 0955 & 3760 & 1610 & 947 & -... \\
\hline 1000 & 3780 & 1700 & 949 & -... \\
\hline 1005 & 3810 & 1800 & 952 & -... \\
\hline 1010 & 3850 & 1910 & 954 & -... \\
\hline 1015 & 3880 & 2000 & 957 & $\ldots$ \\
\hline 1020 & 3910 & 2120 & 966 & -..- \\
\hline 1025 & 3950 & 2220 & 974 &.-- \\
\hline 1030 & 3970 & 2300 & 982 & $\ldots$ \\
\hline 1035 & 3990 & 2390 & 991 & $\ldots$ \\
\hline 1040 & 3970 & 2470 & 1000 & -..- \\
\hline 1045 & 3960 & 2560 & 1030 & $\ldots$ \\
\hline 1050 & 3940 & 2640 & 1050 & \\
\hline 1055 & 3920 & 2720 & 1080 & 1080 \\
\hline 1100 & 3920 & 2800 & 1120 & $\ldots$ \\
\hline 1105 & 3940 & 2870 & 1160 & $\ldots$ \\
\hline 1110 & 3970 & 2920 & 1210 & $\ldots$ \\
\hline 1115 & 4000 & 2990 & 1250 & $\ldots$ \\
\hline 1120 & 4020 & 3070 & 1300 & -.. \\
\hline 1125 & 4050 & 3140 & 1350 & $\ldots$ \\
\hline 1130 & 4080 & 3200 & 1420 & $\ldots$ \\
\hline 1135 & 4090 & 3250 & 1490 & $\ldots$ \\
\hline 1140 & 4080 & 3290 & 1560 & --- \\
\hline 1145 & 4060 & 3340 & 1640 & -... \\
\hline 1150 & 4060 & 3400 & 1720 & $-\ldots$ \\
\hline 1155 & 4060 & 3440 & 1800 & .... \\
\hline 1200 & 4050 & 3480 & 1890 & - \\
\hline 1205 & 4040 & 3500 & 1980 & -... \\
\hline 1210 & 4040 & 3540 & 2060 & $\ldots$ \\
\hline 1215 & 4070 & 3570 & 2130 & $\ldots$ \\
\hline 1220 & 4050 & 3600 & 2200 & $\ldots$ \\
\hline 1225 & 4060 & 3630 & 2260 & $-\ldots$ \\
\hline 1230 & 4070 & 3650 & 2330 & $\cdots$ \\
\hline 1235 & 4080 & 3670 & 2410 & $\ldots$ \\
\hline 1240 & 4100 & 3680 & 2510 & $\cdots$ \\
\hline 1245 & 4100 & 3700 & 2600 & \\
\hline 1250 & 4110 & 3710 & 2690 & 1170 \\
\hline 1255 & 4130 & 3720 & 2790 & 1180 \\
\hline 1300 & 4140 & 3730 & 2880 & 1320 \\
\hline 1305 & 4160 & 3740 & 2950 & 1420 \\
\hline 1310 & 4170 & 3760 & 3010 & 1460 \\
\hline 1315 & 4180 & 3780 & 3060 & 1510 \\
\hline 1320 & 4190 & 3810 & 3120 & 1560 \\
\hline 1325 & 4200 & 3830 & 3170 & 1610 \\
\hline 1330 & 4210 & 3920 & 3200 & 1660 \\
\hline 1335 & 4220 & 3950 & 3260 & 1700 \\
\hline 1340 & 4230 & 3980 & 3310 & 1760 \\
\hline 1345 & 4240 & 4000 & 3350 & 1840 \\
\hline 1350 & 4250 & 4030 & 3400 & 1910 \\
\hline 1355 & 4260 & 4060 & 3430 & 2020 \\
\hline 1400 & 4270 & 4070 & 3470 & 2090 \\
\hline 1405 & 4280 & 4020 & 3510 & 2150 \\
\hline 1410 & 4290 & 4070 & 3560 & 2220 \\
\hline 1415 & 4300 & 4080 & 3600 & 2300 \\
\hline 1420 & 4310 & 4080 & 3640 & 2400 \\
\hline
\end{tabular}


TABLE 11.-Summary of river discharge data-Continued

\begin{tabular}{|c|c|c|c|c|}
\hline \multirow[b]{2}{*}{$\begin{array}{l}\text { Date and } \\
\text { Time }\end{array}$} & \multicolumn{4}{|c|}{ Discharge, in $\mathrm{ft}^{3} / \mathrm{s}$} \\
\hline & $\begin{array}{c}\text { Georgia } \\
\text { Highway } 20\end{array}$ & $\begin{array}{c}\text { Littles } \\
\text { Ferry Bridge }\end{array}$ & $\begin{array}{c}\text { Georgia } \\
\text { Highway } 120\end{array}$ & $\begin{array}{c}\text { Georgia } \\
\text { Highway } 141\end{array}$ \\
\hline \multicolumn{5}{|c|}{ March 22, 1976 : } \\
\hline 1425 & 4320 & 4080 & 3680 & 2500 \\
\hline 1430 & 4330 & 4080 & 3710 & 2590 \\
\hline 1435 & 4340 & 4080 & 3740 & 2700 \\
\hline 1440 & 4350 & 4080 & 3780 & 2810 \\
\hline 1445 & 4360 & 4090 & 3800 & 2920 \\
\hline 1450 & 4370 & 4100 & 3830 & 3050 \\
\hline 1455 & 4370 & 4110 & 3860 & 3170 \\
\hline 1500 & 4370 & 4100 & 3890 & 3260 \\
\hline 1505 & 4370 & 4100 & 3900 & 3330 \\
\hline 1510 & 4360 & 4100 & 3910 & 3410 \\
\hline 1515 & 4340 & 4100 & 3930 & 3480 \\
\hline 1520 & 4330 & 4110 & 3950 & 3540 \\
\hline 1525 & 4320 & 4110 & 3960 & 3620 \\
\hline 1530 & 4310 & 4110 & 3980 & 3760 \\
\hline 1535 & 4290 & 4110 & 3990 & 3700 \\
\hline 1540 & 4280 & 4120 & 4000 & 3720 \\
\hline 1545 & 4270 & 4120 & 4020 & 3740 \\
\hline 1550 & 4250 & 4130 & 4030 & 3740 \\
\hline 1555 & 4240 & 4130 & 4040 & 3740 \\
\hline 1600 & 4230 & 4140 & 4040 & 3740 \\
\hline 1605 & 4220 & 4140 & 4050 & 3760 \\
\hline 1610 & 4240 & 4150 & 4060 & 3780 \\
\hline 1615 & 4250 & 4170 & 4070 & 3820 \\
\hline 1620 & 4280 & 4170 & 4080 & 3880 \\
\hline 1625 & 4310 & 4170 & 4080 & 3840 \\
\hline 1630 & 4340 & 4170 & 4090 & ---- \\
\hline 1635 & $\ldots$ & 4170 & 4100 & --- \\
\hline 1640 & $-\ldots$ & 4180 & 4100 & $-0-1$ \\
\hline 1645 & $\ldots$ & 4180 & 4110 & -1 \\
\hline 1650 & $-\ldots$ & 4180 & 4120 & --1 \\
\hline 1655 & 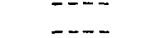 & 4180 & 4130 & 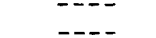 \\
\hline 1700 & --- & 4180 & 4140 & ---- \\
\hline 1705 & $\ldots$ & 4180 & 4150 & $-0-$ \\
\hline 1710 & ---- & 4180 & 4160 & - \\
\hline 1715 & --- & 4170 & 4170 & --- \\
\hline 1720 & $\ldots$ & 4150 & 4180 & $\begin{array}{l}--- \\
---\end{array}$ \\
\hline 1725 & $\ldots$ & 4140 & 4200 & $--\overline{-}$ \\
\hline 1730 & ---- & 4130 & 4210 & 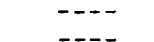 \\
\hline 1735 & ---- & 4110 & 4220 & --- \\
\hline 1740 & - & 4100 & 4240 & --- \\
\hline 1745 & --0 & 4180 & 4260 & $-\cdots$ \\
\hline 1750 & 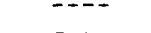 & 4160 & 4280 & --- \\
\hline 1755 & ---- & 4140 & $\begin{array}{l}4200 \\
4310\end{array}$ & --- \\
\hline 1800 & --- & 4120 & & --- \\
\hline 1805 & $\cdots$ & & $\begin{array}{l}4300 \\
4320\end{array}$ & $\ldots-$ \\
\hline 1810 & --- & $-\cdots-$ & $\begin{array}{l}4320 \\
4330\end{array}$ & $-\cdots$ \\
\hline 1815 & --- & $\cdots-$ & 4330 & --- \\
\hline 1820 & --- & --- & 4310 & -- \\
\hline 1825 & ---- & -- & 4290 & --- \\
\hline 1830 & --- & ---- & 4270 & --- \\
\hline 1835 & --- & ---- & $\ldots$ & $-\cdots$ \\
\hline 1840 & ---- & --- & $-\cdots$ & --- \\
\hline 1845 & ---- & $-\cdots$ & --- & ---- \\
\hline $\begin{array}{l}1040 \\
1850\end{array}$ & $---\Delta$ & ---- & --- & $\ldots$ \\
\hline 1850 & ---- & --- & --- & ---- \\
\hline 1855 & --- & --- & --- & --- \\
\hline 1900 & --- & $-\ldots$ & $-\ldots$ & ---- \\
\hline 1905 & ---- & 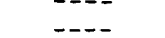 & $\begin{array}{ll}--0- \\
---\end{array}$ & $0-0$ \\
\hline 1910 & ---- & 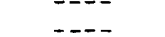 & ---- & $-0-1$ \\
\hline
\end{tabular}


TABLE 11.-Summary of river discharge data-Continued

\begin{tabular}{|c|c|c|c|c|}
\hline \multirow[b]{2}{*}{$\begin{array}{l}\text { Date and } \\
\text { Time }\end{array}$} & \multicolumn{4}{|c|}{ Discharge, in $\mathrm{ft}^{3} / \mathrm{s}$} \\
\hline & $\begin{array}{c}\text { Georgia } \\
\text { Highway } 20\end{array}$ & $\begin{array}{c}\text { Littles } \\
\text { Ferry Bridge }\end{array}$ & $\begin{array}{c}\text { Georgia } \\
\text { Highway } 120\end{array}$ & $\begin{array}{c}\text { Georgia } \\
\text { Highway } 141\end{array}$ \\
\hline \multicolumn{5}{|l|}{ March 22, 1976: } \\
\hline 1915 & -..- & -..- & - . & -... \\
\hline 1920 & $\ldots$ & -..- & --- & - - \\
\hline 1925 & $-\ldots$ & -- & $\ldots$ & $-\cdots$ \\
\hline 1930 & $-\ldots$ & -... & $\ldots$ & -... \\
\hline 1935 & $\ldots$ & --- & $\ldots$ & --- \\
\hline 1940 & $\ldots$ & -... & - . - & -... \\
\hline 1945 & -.-- & $\ldots$ & $\ldots$ & $-\ldots$ \\
\hline \multicolumn{5}{|c|}{ March 23, 1976 : } \\
\hline 0610 & $\ldots$ & -- & -- & --- \\
\hline 0615 & -.-- & -..- & - - - & - - \\
\hline 0620 & $\ldots$ & - - & --.- & -- \\
\hline 0625 & $\ldots$ & - - & $\ldots$ & -..- \\
\hline 0630 & $\ldots$ & $-\ldots$ & -- & -- \\
\hline 0635 & $\ldots$ & -..- & -.-- & -... \\
\hline 0640 & -... & -..- & -..- & $-\cdots$ \\
\hline 0645 & $\ldots$ & -... & - - & $-\cdots$ \\
\hline 0650 & -- & - - & $\ldots$ & -- \\
\hline 0655 & & $-\cdots$ & -... & -- \\
\hline 0700 & 540 & $\ldots$ & $-\cdots$ & $-\cdots$ \\
\hline 0705 & 540 & -- & $-\cdots$ & ... \\
\hline 0710 & $-\ldots$ & - - & $-\cdots$ & -- \\
\hline 0715 & & $\ldots$ & $\ldots$ & $\ldots$ \\
\hline 0720 & 1140 & -- & $\ldots$ & $-\cdots$ \\
\hline 0725 & 1550 & $\ldots$ & $-\cdots$ & --- \\
\hline 0730 & 2000 & -... & $-\cdots$ & $\cdots$ \\
\hline 0735 & 2610 & -- & $-\ldots$ & --.- \\
\hline 0740 & 3550 & -..- & -... & $\ldots$ \\
\hline 0745 & 4250 & $\ldots$ & $-\ldots$ & -- \\
\hline 0750 & 4880 & $\ldots$ & $\ldots$ & $\ldots$ \\
\hline 0755 & 5750 & 830 & $\ldots$ & $\ldots$ \\
\hline 0800 & 6050 & 830 & - & $\ldots$ \\
\hline 0805 & 6360 & 830 & $\ldots$ & 1860 \\
\hline 0810 & 6680 & 830 & $\ldots$ & 1850 \\
\hline 0815 & 6970 & 830 & $\ldots$ & 1840 \\
\hline 0820 & 7220 & 830 & $\ldots$ & 1820 \\
\hline 0825 & 7400 & 830 & $\ldots$ & 1810 \\
\hline 0830 & 7450 & 830 & $-\ldots$ & 1800 \\
\hline 0835 & 7500 & 830 & $-\cdots$ & 1780 \\
\hline 0840 & 7540 & 830 & $\ldots$ & 1770 \\
\hline 0845 & 7590 & 830 & $-\ldots$ & 1750 \\
\hline 0850 & 7630 & 830 & $\ldots$ & 1740 \\
\hline 0855 & 7710 & 1020 & $\ldots$ & 1730 \\
\hline 0900 & 7770 & 1200 & -..- & 1710 \\
\hline 0905 & 7820 & 1440 & $\ldots$ & 1700 \\
\hline 0910 & 7850 & 1650 & $\ldots$ & 1690 \\
\hline 0915 & 7860 & 1890 & $\ldots$ & 1680 \\
\hline 0920 & 7870 & 2100 & $\ldots$ & 1660 \\
\hline 0925 & 7860 & 2270 & -- & 1650 \\
\hline 0930 & 7840 & 2440 & $\ldots$ & 1640 \\
\hline 0935 & 7850 & 2650 & $-\ldots$ & 1620 \\
\hline 0940 & 7900 & 2910 & - & 1610 \\
\hline 0945 & 7970 & 3260 & $\ldots$ & 1600 \\
\hline 0950 & 8060 & 3730 & $\ldots$ & 1580 \\
\hline 0955 & 8150 & 4000 & - & 1570 \\
\hline 1000 & 8220 & 4180 & - & 1560 \\
\hline 1005 & 8320 & 4330 & 1100 & 1550 \\
\hline 1010 & 8420 & 4440 & 1100 & 1540 \\
\hline
\end{tabular}


TABLE 11.-Summary of river discharge data-Continued

\begin{tabular}{|c|c|c|c|c|}
\hline \multirow[b]{2}{*}{$\begin{array}{l}\text { Date and } \\
\text { Time }\end{array}$} & \multicolumn{4}{|c|}{ Discharge, in $\mathrm{ft}^{3} / \mathrm{s}$} \\
\hline & $\begin{array}{c}\text { Georgia } \\
\text { Highway } 20\end{array}$ & $\begin{array}{c}\text { Littles } \\
\text { Ferry Bridge }\end{array}$ & $\begin{array}{c}\text { Georgia } \\
\text { Highway } 120\end{array}$ & $\begin{array}{c}\text { Georgia } \\
\text { Highway } 141\end{array}$ \\
\hline \multicolumn{5}{|c|}{ March 23, 1976: } \\
\hline 1015 & 8420 & 4610 & 1110 & 1520 \\
\hline 1020 & 8360 & 4740 & 1380 & 1510 \\
\hline 1025 & 8310 & 4850 & 1500 & 1500 \\
\hline 1030 & 8240 & 5030 & 1610 & 1500 \\
\hline 1035 & 8160 & 5190 & 1720 & 1490 \\
\hline 1040 & 8090 & 5550 & 1840 & 1490 \\
\hline 1045 & 8020 & 5720 & 2020 & 1490 \\
\hline 1050 & 8030 & 5900 & 2190 & 1490 \\
\hline 1055 & 8060 & 6110 & 2330 & 1490 \\
\hline 1100 & 8080 & 6310 & 2480 & 1490 \\
\hline 1105 & 8160 & 6490 & 2620 & 1490 \\
\hline 1110 & 8260 & 6620 & 2780 & 1490 \\
\hline 1115 & 8360 & 6730 & 3020 & 1490 \\
\hline 1120 & 8450 & 6840 & 3230 & 1490 \\
\hline 1125 & 8540 & 6940 & 3470 & 1500 \\
\hline 1130 & 8610 & 7040 & 3750 & 1540 \\
\hline 1135 & 8660 & 7140 & 3990 & 1590 \\
\hline 1140 & 8600 & 7220 & 4220 & 1640 \\
\hline 1145 & 8480 & 7300 & 4460 & 1720 \\
\hline 1150 & 8250 & 7370 & 4700 & 1810 \\
\hline 1155 & 7860 & 7440 & 5020 & 1900 \\
\hline 1200 & 7320 & 7500 & 5290 & 2020 \\
\hline 1205 & 6860 & 7550 & 5480 & 2120 \\
\hline 1210 & 6320 & 7610 & 5600 & 2250 \\
\hline 1215 & 5810 & 7650 & 5720 & 2390 \\
\hline 1220 & 5340 & 7670 & 5840 & 2560 \\
\hline 1225 & 4940 & 7660 & 5870 & 2780 \\
\hline 1230 & 4640 & 7610 & 5900 & 2970 \\
\hline 1235 & 4380 & 7540 & 5950 & 3170 \\
\hline 1240 & 4130 & 7450 & 6020 & 3300 \\
\hline 1245 & 3900 & 7350 & 6100 & 3480 \\
\hline 1250 & 3650 & 7240 & 6180 & 3640 \\
\hline 1255 & 3390 & 7140 & 6260 & 3760 \\
\hline 1300 & 3150 & 7040 & 6400 & 3950 \\
\hline 1305 & 2930 & 6890 & 6570 & 4110 \\
\hline 1310 & 2730 & 6750 & 6740 & 4290 \\
\hline 1315 & 2550 & 6630 & 6900 & 4490 \\
\hline 1320 & 2420 & 6500 & 7010 & 4686 \\
\hline 1325 & 2290 & 6350 & 7060 & 4800 \\
\hline 1330 & 2180 & 6180 & 7000 & 5000 \\
\hline 1335 & 2080 & 5990 & 6920 & 5190 \\
\hline 1340 & 2000 & 5810 & 6860 & 5390 \\
\hline 1345 & 1920 & 5650 & 6790 & 5590 \\
\hline 1350 & 1860 & 5510 & 6740 & 5780 \\
\hline 1355 & 1810 & 5390 & 6750 & 5880 \\
\hline 1400 & 1760 & 5270 & 6740 & 5920 \\
\hline 1405 & 1720 & 5150 & 6740 & 6020 \\
\hline 1410 & 1760 & 5060 & 6750 & 6130 \\
\hline 1415 & 1620 & 4940 & 6710 & 6260 \\
\hline 1420 & 1570 & 4840 & 6620 & 6380 \\
\hline 1425 & 1530 & 4750 & 6550 & 6460 \\
\hline 1430 & 1490 & 4660 & 6490 & 6520 \\
\hline 1435 & 1440 & 4570 & 6412 & 6540 \\
\hline 1440 & 1400 & 4480 & 6350 & 6550 \\
\hline 1445 & 1360 & 4390 & 6330 & 6550 \\
\hline 1450 & 1340 & 4310 & 6320 & 6540 \\
\hline 1455 & 1310 & 4230 & 6300 & 6520 \\
\hline 1500 & 1280 & 4150 & 6290 & 6480 \\
\hline
\end{tabular}


TABLE 11.-Summary of river discharge data-Continued

\begin{tabular}{|c|c|c|c|c|}
\hline \multirow[b]{2}{*}{$\begin{array}{l}\text { Date and } \\
\text { Time }\end{array}$} & \multicolumn{4}{|c|}{ Discharge, in $\mathrm{ft}^{3} / \mathrm{s}$} \\
\hline & $\begin{array}{c}\text { Georgia } \\
\text { Highway } 20\end{array}$ & $\begin{array}{c}\text { Littles } \\
\text { Ferry Bridge }\end{array}$ & $\begin{array}{c}\text { Georgia } \\
\text { Highway } 120\end{array}$ & $\begin{array}{c}\text { Georgia } \\
\text { Highway } 14\end{array}$ \\
\hline \multicolumn{5}{|l|}{ March 23, 1976: } \\
\hline 1505 & 1240 & 4050 & 6260 & 6440 \\
\hline 1510 & 1210 & 3960 & 6200 & 6380 \\
\hline 1515 & 1170 & 3860 & 6100 & 6330 \\
\hline 1520 & 1130 & 3790 & 6000 & 6270 \\
\hline 1525 & 1100 & 3680 & 5890 & 6220 \\
\hline 1530 & 1060 & 3580 & 5780 & 6180 \\
\hline 1535 & 1040 & 3490 & 5690 & 6140 \\
\hline 1540 & 1010 & 3380 & 5600 & 6100 \\
\hline 1545 & 980 & 3280 & 5520 & 6070 \\
\hline 1550 & 960 & 3210 & 5480 & 6030 \\
\hline 1555 & 940 & 3160 & 5320 & 6000 \\
\hline 1600 & 920 & 3100 & 5180 & 5970 \\
\hline 1605 & 900 & 3040 & 5070 & 5940 \\
\hline 1610 & 880 & 2990 & 5010 & 5920 \\
\hline 1615 & 870 & 2850 & 4950 & 5890 \\
\hline 1620 & 850 & 2800 & 4900 & 5870 \\
\hline 1625 & 840 & 2760 & 4840 & 5850 \\
\hline 1630 & 830 & 2700 & 4790 & 5830 \\
\hline 1635 & 820 & 2660 & 4630 & 5800 \\
\hline 1640 & 810 & 2610 & 4530 & 5780 \\
\hline 1645 & 790 & 2560 & 4420 & 5760 \\
\hline 1650 & 780 & 2510 & 4280 & 5710 \\
\hline 1655 & 770 & 2480 & 4190 & 5670 \\
\hline 1700 & 770 & 2440 & 4150 & 5620 \\
\hline 1705 & 760 & 2410 & 4070 & 5560 \\
\hline 1710 & 760 & 2370 & 4000 & 5510 \\
\hline 1715 & 750 & 2340 & 3930 & 5460 \\
\hline 1720 & 750 & 2300 & 3870 & 5410 \\
\hline 1725 & 740 & 2250 & 3790 & 5370 \\
\hline 1730 & $\ldots$ & 2210 & 3720 & 5320 \\
\hline 1735 & -.-. & 2180 & 3660 & 5270 \\
\hline 1740 & -1 & 2140 & 3620 & 5210 \\
\hline 1745 & $\ldots$ & 2100 & 3570 & 5160 \\
\hline 1750 & $\cdots$ & 2060 & 3530 & 5110 \\
\hline 1755 & - - - & 2000 & 3480 & 5020 \\
\hline 1800 & --1 & 1950 & 3430 & 4950 \\
\hline 1805 & - - - & 1910 & 3390 & 4870 \\
\hline 1810 & $-\ldots$ & 1880 & 3340 & 4790 \\
\hline 1815 & -- & 1840 & 3310 & 4700 \\
\hline 1820 & $-1-$ & 1820 & 3280 & 4620 \\
\hline 1825 & $\ldots$ & 1790 & 3250 & 4540 \\
\hline 1830 & $\ldots$ & 1760 & 3210 & 4490 \\
\hline 1835 & -1 & 1720 & 3140 & 4430 \\
\hline 1840 & $-\ldots$ & 1690 & 3070 & 4370 \\
\hline 1845 & 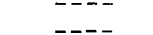 & 1650 & 2980 & 4300 \\
\hline 1850 & - - - & 1620 & 2910 & 4230 \\
\hline 1855 & -1 & 1580 & 2850 & 4160 \\
\hline 1900 & -_- & 1540 & 2810 & 4100 \\
\hline 1905 & -1 & 1510 & 2780 & 4050 \\
\hline 1910 & $\ldots$ & 1470 & 2750 & 4000 \\
\hline 1915 & $\ldots$ & 1450 & 2720 & 3930 \\
\hline 1920 & $\ldots$ & 1430 & 2690 & 3870 \\
\hline 1925 & $\ldots$ & 1410 & 2660 & 3800 \\
\hline 1930 & $\ldots$ & 1380 & 2630 & 3740 \\
\hline 1935 & $\ldots$ & 1360 & 2600 & 3670 \\
\hline 1940 & $\ldots$ & 1340 & 2550 & 3610 \\
\hline 1945 & $\cdots$ & 1310 & 2490 & 3570 \\
\hline 1950 & - - & 1280 & 2420 & 3510 \\
\hline 1955 & -1 & 1250 & 2350 & 3470 \\
\hline
\end{tabular}


TABLE 11.-Summary of river discharge data-Continued

\begin{tabular}{|c|c|c|c|c|}
\hline \multirow[b]{2}{*}{$\begin{array}{l}\text { Date and } \\
\text { Time }\end{array}$} & \multicolumn{4}{|c|}{ Discharge, in $\mathrm{ft}^{3} / \mathrm{s}$} \\
\hline & $\begin{array}{c}\text { Georgia } \\
\text { Highway } 20\end{array}$ & $\begin{array}{c}\text { Littles } \\
\text { Ferry Bridge }\end{array}$ & $\begin{array}{c}\text { Georgia } \\
\text { High way } 120\end{array}$ & $\begin{array}{c}\text { Georgia } \\
\text { Highway } 141\end{array}$ \\
\hline \multicolumn{5}{|l|}{ March 23, 1976: } \\
\hline 2000 & .... & 1230 & 2270 & 3430 \\
\hline 2005 & .... & 1210 & 2240 & 3350 \\
\hline 2010 & $\ldots$ & 1190 & 2200 & 3260 \\
\hline 2015 & $\ldots$ & 1170 & 2170 & 3190 \\
\hline 2020 & -... & 1150 & 2140 & 3110 \\
\hline 2025 & $\ldots$ & 1130 & 2110 & 3040 \\
\hline 2030 & $\ldots$ & 1120 & 2080 & 2980 \\
\hline 2035 & $\ldots$ & 1100 & 2010 & 2930 \\
\hline 2040 & -.. & 1090 & 2000 & 2880 \\
\hline 2045 & $\ldots$ & 1080 & 1970 & 2840 \\
\hline 2050 & $\ldots$ & 1060 & 1940 & 2800 \\
\hline 2055 & $\ldots$ & 1050 & 1910 & 2770 \\
\hline 2100 & $\ldots$ & 1040 & 1880 & 2750 \\
\hline 2105 & $-\ldots$ & 1020 & 1850 & 2730 \\
\hline 2110 & -... & 1010 & 1830 & 2700 \\
\hline 2115 & -..- & 1000 & 1820 & 2670 \\
\hline 2120 & $\ldots$ & 980 & 1810 & 2640 \\
\hline 2125 & -... & 970 & 1800 & 2610 \\
\hline 2130 & -..- & 960 & 1780 & 2580 \\
\hline 2135 & $-\ldots$ & $\ldots$ & 1770 & 2550 \\
\hline 2140 & $-\ldots$ & $\ldots$ & 1750 & 2530 \\
\hline 2145 & -.-- & -... & 1720 & 2500 \\
\hline 2150 & -..- & .... & 1690 & 2470 \\
\hline 2155 & -... & -..- & 1670 & 2450 \\
\hline 2200 & -... & $\ldots$ & 1650 & 2420 \\
\hline 2205 & $\ldots$ & $\ldots$ & 1620 & 2400 \\
\hline 2210 & -... & $\ldots$ & 1610 & 2380 \\
\hline 2215 & - - & -..- & 1590 & 2350 \\
\hline 2220 & -... & $\ldots$ & 1570 & 2320 \\
\hline 2225 & $\ldots$ & $\ldots$ & 1540 & 2300 \\
\hline 2230 & .... & .... & 1530 & 2270 \\
\hline 2235 & -... & -.- & 1500 & 2240 \\
\hline 2240 & -... & - & 1470 & 2220 \\
\hline 2245 & $\ldots$ & -..- & 1460 & 2190 \\
\hline 2250 & ---- & -... & 1440 & 2150 \\
\hline 2255 & -... & $\ldots$ & 1430 & 2120 \\
\hline 2300 & -... & $\ldots$ & 1410 & 2090 \\
\hline 2305 & -... & $\ldots$ & 1400 & 2050 \\
\hline 2310 & ... & .... & 1380 & 2000 \\
\hline 2315 & $\ldots$ & $\ldots$ & 1380 & 1950 \\
\hline 2320 & -... & $\ldots$ & 1360 & $\ldots$ \\
\hline 2325 & $\ldots$ & $\ldots$ & 1360 & - - \\
\hline 2330 & $\ldots$ & $\ldots$ & 1350 & -... \\
\hline 2335 & -... & -... & 1340 & -..- \\
\hline 2340 & $\ldots$ & ---. & 1330 & -..- \\
\hline 2345 & -... & -..- & 1320 & $\ldots$ \\
\hline 2350 & $\ldots$ & --- & 1300 & -.-. \\
\hline 2355 & -... & -..- & 1280 & .... \\
\hline
\end{tabular}


TABLE 12.-Summary of tributary discharge data

\begin{tabular}{|c|c|c|c|c|c|}
\hline \multirow[b]{2}{*}{$\begin{array}{c}\text { Date and } \\
\text { Time }\end{array}$} & \multicolumn{5}{|c|}{ Discharge, in $\mathrm{ft}^{3} / \mathrm{s}$} \\
\hline & $\begin{array}{c}\text { Richland } \\
\text { Creek }\end{array}$ & $\begin{array}{l}\text { James } \\
\text { Creek }\end{array}$ & $\begin{array}{l}\text { Level } \\
\text { Creek }\end{array}$ & $\begin{array}{c}\text { Dick } \\
\text { Creek }\end{array}$ & $\begin{array}{c}\text { Suwannee } \\
\text { Creek }\end{array}$ \\
\hline \multicolumn{6}{|l|}{ March 21, 1976: } \\
\hline 1023 & & 69 & -- & -- & $-\ldots$ \\
\hline 1035 & 51 & & -- & -- & -- \\
\hline 1123 & -- & 69 & -- & $\overline{0}$ & -- \\
\hline 1230 & - & -- & $\approx$ & 29 & --- \\
\hline 1317 & -- & -. & 39 & -. & \\
\hline 1840 & -- & - & -- & -- & 250 \\
\hline \multicolumn{6}{|l|}{ March 22. 1976: } \\
\hline 1010 & -- & -- & & -- & 165 \\
\hline 1030 & -- & -- & 22 & -. & -.- \\
\hline 1051 & 21 & $-\bar{c}$ & - & - & --- \\
\hline 1150 & -. & 60 & -- & "̄ & -- \\
\hline 1220 & -- & $\cdots$ & -- & 22 & $\overline{1}$ \\
\hline 1245 & - & - & $\overline{-1}$ & - & 163 \\
\hline 1315 & $\overline{2} \overline{9}$ & -- & 24 & - & -- \\
\hline 1330 & 29 & $\bar{s}$ & -- & -- & --- \\
\hline 1415 & -- & 60 & -- & $\overline{0}$ & --- \\
\hline 1430 & -- & -- & -- & 22 & $\overline{10}$ \\
\hline 1445 & -- & - & $\overline{2} \overline{5}$ & -- & 170 \\
\hline $\begin{array}{l}1550 \\
1520\end{array}$ & 29 & -- & 25 & -- & -- \\
\hline $\begin{array}{l}1520 \\
1600\end{array}$ & 20 & -- & -- & $\overline{0}$ & $\cdots$ \\
\hline $\begin{array}{l}1600 \\
1625\end{array}$ & -- & -- & -- & 22 & \\
\hline $\begin{array}{l}1625 \\
1640\end{array}$ & -- & -- & $\overline{25}$ & $\cdots$ & 168 \\
\hline 1640 & $\overline{2} \overline{9}$ & -- & $2 b$ & -- & -- \\
\hline 1700 & 29 & $\overline{0}$ & -- & -- & -- \\
\hline 1720 & -- & 60 & -- & -- & -.- \\
\hline \multicolumn{6}{|l|}{ March 23, 1976: } \\
\hline 1225 & -. & & -- & 22 & -- \\
\hline 1240 & $\overline{0}$ & 35 & -- & -- & -- \\
\hline 1315 & 22 & -- & -- & -- & $-\overline{0}$ \\
\hline 1410 & -- & -- & - & -- & 130 \\
\hline \multicolumn{6}{|l|}{ March 24, 1976: } \\
\hline 0840 & -- & -- & -- & -. & 120 \\
\hline 0920 & $\overline{0}$ & -- & 9 & -- & --- \\
\hline $\begin{array}{l}1000 \\
1038\end{array}$ & $\begin{array}{l}21 \\
-\end{array}$ & $\overline{30}$ & - & -- & --- \\
\hline 1052 & - & - & -- & $\overline{12}$ & --- \\
\hline
\end{tabular}


TABLE 13.-Summary of cross-8ection data

\begin{tabular}{|c|c|c|c|c|c|c|c|}
\hline \multicolumn{2}{|c|}{ River mile 330.77} & \multicolumn{2}{|c|}{ River mile 331.41} & \multicolumn{2}{|c|}{ River mile 33190} & \multicolumn{2}{|c|}{ River mile 332.44} \\
\hline $\begin{array}{l}\text { Horizontal } \\
\text { distance } \\
\text { (ft) }\end{array}$ & $\begin{array}{c}\text { Altitude } \\
\text { (ft) }\end{array}$ & $\begin{array}{l}\text { Horizontal } \\
\text { distance } \\
(\mathrm{ft})\end{array}$ & $\begin{array}{c}\text { Altitude } \\
\text { (ft) }\end{array}$ & $\begin{array}{l}\text { Horizontal } \\
\text { distance } \\
(\mathrm{ft})\end{array}$ & $\begin{array}{c}\text { Altitude } \\
\text { (ft) }\end{array}$ & $\begin{array}{l}\text { Horizontal } \\
\text { distance } \\
(\mathrm{ft})\end{array}$ & $\begin{array}{c}\text { Altitude } \\
\text { (ft) }\end{array}$ \\
\hline 90.0 & 893.20 & 15.0 & 897.6 & 49.0 & 895.0 & 75.0 & 896.0 \\
\hline 130.0 & 891.40 & 43.0 & 886.7 & 50.0 & 892.0 & 79.5 & 894.0 \\
\hline 150.0 & 885.92 & 45.0 & 882.4 & 51.0 & 887.4 & 87.5 & 881.9 \\
\hline 156.0 & 880.22 & 54.0 & 882.3 & 51.5 & 883.3 & 89.5 & 882.7 \\
\hline 166.0 & 877.42 & 70.0 & 877.3 & 68.0 & 879.6 & 97.5 & 882.0 \\
\hline 176.0 & 878.62 & 79.0 & 878.4 & 76.0 & 879.7 & 103.0 & 880.0 \\
\hline 191.0 & 876.62 & 123.5 & 879.8 & 110.0 & 880.3 & 112.0 & 879.4 \\
\hline 216.0 & 877.02 & 151.0 & 879.8 & 137.5 & 879.5 & 139.0 & 879.5 \\
\hline 236.0 & 877.02 & 166.0 & 879.6 & 140.0 & 879.5 & 149.0 & 879.8 \\
\hline 256.0 & 876.52 & 173.0 & 879.8 & 155.0 & 880.3 & 190.0 & 880.3 \\
\hline 276.0 & 876.92 & 211.5 & 879.8 & 178.5 & 880.1 & 219.0 & 880.8 \\
\hline 296.0 & 875.12 & 224.0 & 879.6 & 236.0 & 882.5 & 255.5 & 879.7 \\
\hline 316.0 & 875.42 & 233.0 & 879.3 & 243.0 & 882.7 & 267.0 & 880.1 \\
\hline 326.0 & 873.92 & 250.0 & 880.7 & 243.5 & 887.4 & 257.0 & 882.0 \\
\hline 331.0 & 873.42 & 252.0 & 886.7 & 245.0 & 890.2 & 274.0 & 883.6 \\
\hline 346.0 & 874.72 & 255.0 & 894.0 & 246.0 & 895.0 & 283.0 & 883.6 \\
\hline 355.0 & 877.62 & $\ldots$ & $\ldots$ & $\ldots$ & $\ldots$ & 284.0 & 881.9 \\
\hline 364.0 & 881.62 & $\ldots$ & $\ldots$ & $\ldots$ & --- & 285.5 & 892.2 \\
\hline 368.0 & 885.92 & --- & $\ldots$ & $-\ldots$ & $\ldots$ & 286.0 & 896.0 \\
\hline 380.0 & 889.40 & $\ldots$ & $\ldots$ & & & & \\
\hline \multicolumn{2}{|c|}{ River mile 332.81} & \multicolumn{2}{|c|}{ River mile 333.13} & \multicolumn{2}{|c|}{ River mile 333.65} & \multicolumn{2}{|c|}{ River mile 334.25} \\
\hline $\begin{array}{l}\text { Horizontal } \\
\text { distance } \\
\text { (ft) }\end{array}$ & $\begin{array}{c}\text { Altitude } \\
(\mathrm{ft})\end{array}$ & $\begin{array}{l}\text { Horizontal } \\
\text { distance } \\
(\mathrm{ft})\end{array}$ & $\begin{array}{c}\text { Altitude } \\
\text { (ft) }\end{array}$ & $\begin{array}{l}\text { Horizontal } \\
\text { distance } \\
\text { (ft) }\end{array}$ & $\begin{array}{c}\text { Altitude } \\
\text { (ft) }\end{array}$ & $\begin{array}{l}\text { Horizontal } \\
\text { distance } \\
(\mathrm{ft})\end{array}$ & $\begin{array}{c}\text { Altitude } \\
\text { (ft) }\end{array}$ \\
\hline-12.0 & 895.0 & 15.0 & 902.0 & 20.0 & 899.0 & 1.0 & 898.0 \\
\hline 2.0 & 892.0 & 22.5 & 889.0 & 40.0 & 898.5 & 20.0 & 884.5 \\
\hline 15.5 & 882.2 & 24.0 & 883.0 & 60.0 & 884.4 & 50.0 & 878.4 \\
\hline 30.0 & 877.3 & 29.5 & 883.1 & 88.0 & 879.4 & 100.0 & 878.4 \\
\hline 52.0 & 878.2 & 35.5 & 882.9 & 199.0 & 879.5 & 150.0 & 880.3 \\
\hline 100.0 & 878.6 & 43.0 & 882.1 & 224.0 & 884.5 & 176.0 & 884.5 \\
\hline 150.5 & 878.0 & 46.0 & 878.9 & 240.0 & 897.3 & 190.0 & 897.5 \\
\hline 174.0 & 882.2 & 64.0 & 880.5 & $-\cdots$ &.-- & --- & $-\ldots$ \\
\hline 194.0 & 894.5 & 94.0 & 881.3 & -- & $\ldots$ & --- & $-\ldots$ \\
\hline$\ldots$ & -- & 108.5 & 881.7 & $\ldots$ & $\ldots$ & --- & - . \\
\hline$\ldots$ & $-\ldots$ & 155.0 & 882.2 & --- & $-\cdots$ & $-\cdots$ & -- \\
\hline$\ldots$ & $-\ldots$ & 175.0 & 882.0 & -... & $\ldots$ & --- & --- \\
\hline$\ldots$ & $\cdots$ & 180.0 & 881.7 & $-\cdots$ & --- & ---- & $\ldots$ \\
\hline$\ldots$ & $\ldots$ & 186.0 & 883.7 & --- & --- & $\ldots$ & --- \\
\hline$\ldots$ & -- & 190.0 & 884.1 & --- & $\ldots$ & --- & $\ldots$ \\
\hline$\ldots$ & $\ldots$ & 192.0 & 889.0 & $\cdots$ & $\ldots$ & --- & --- \\
\hline$-\cdots$ & --- & 193.0 & 893.3 & $-\cdots$ & --- & $-\cdots$ & --- \\
\hline
\end{tabular}


TABLE 13.-Summary of cross-8ection data-Continued

\begin{tabular}{|c|c|c|c|c|c|c|c|}
\hline \multicolumn{2}{|c|}{ River mile 334.78} & \multicolumn{2}{|c|}{ River mile 335.26} & \multicolumn{2}{|c|}{ River mile 335.64} & \multicolumn{2}{|c|}{ River mile 336.31} \\
\hline $\begin{array}{l}\text { Horizontal } \\
\text { distance } \\
\text { (ft) }\end{array}$ & $\begin{array}{c}\text { Altitude } \\
\text { (ft) }\end{array}$ & $\begin{array}{l}\text { Horizontal } \\
\text { distance } \\
\text { (ft) }\end{array}$ & $\begin{array}{c}\text { Altitude } \\
(\mathrm{ft})\end{array}$ & $\begin{array}{l}\text { Horizontal } \\
\text { distance } \\
\text { (ft) }\end{array}$ & $\begin{array}{c}\text { Altitude } \\
\text { (ft) }\end{array}$ & $\begin{array}{l}\text { Horizontal } \\
\text { distance } \\
(\mathrm{ft})\end{array}$ & $\begin{array}{l}\text { Altitude } \\
\text { (ft) }\end{array}$ \\
\hline 15.0 & 898.0 & 97.0 & 898.20 & 15.0 & 895.0 & 15.0 & 903.5 \\
\hline 17.0 & 891.2 & 100.0 & 893.48 & 23.5 & 892.4 & 15.5 & 893.5 \\
\hline 18.5 & 887.9 & 108.0 & 887.18 & 26.0 & 889.3 & 18.0 & 890.7 \\
\hline 25.0 & 887.7 & 118.0 & 885.38 & 45.0 & 883.2 & 29.5 & 890.3 \\
\hline 46.5 & 884.4 & 128.0 & 882.68 & 51.5 & 883.2 & 31.5 & 889.2 \\
\hline 47.5 & 883.9 & 138.0 & 882.88 & 69.5 & 884.6 & 93.0 & 884.9 \\
\hline 54.5 & 882.1 & 148.0 & 882.68 & 106.0 & 882.7 & 100.0 & 884.9 \\
\hline 61.5 & 882.2 & 158.0 & 882.48 & 141.0 & 885.6 & 143.0 & 886.4 \\
\hline 127.5 & 883.1 & 168.0 & 882.58 & 162.0 & 886.0 & 180.5 & 886.4 \\
\hline 164.0 & 881.3 & 178.0 & 883.48 & 164.5 & 886.2 & 195.0 & 890.7 \\
\hline 108.0 & 881.6 & 188.0 & 882.48 & 189.0 & 886.4 & 213.0 & 893.5 \\
\hline 175.5 & 885.7 & 198.0 & 881.48 & 196.0 & 887.6 & 218.5 & 901.5 \\
\hline 176.0 & 891.2 & 208.0 & 880.98 & 205.0 & 887.9 & - & -.- \\
\hline 177.0 & 896.0 & 218.0 & 881.48 & 208.5 & 887.9 & $\ldots$ & $\ldots$ \\
\hline - & $\ldots$ & 228.0 & 880.68 & 215.0 & 892.4 & .... & .... \\
\hline$-\ldots$ & --- & 238.0 & 880.88 & 217.5 & 899.7 & $-\ldots$ & $\ldots$ \\
\hline$\ldots$ & -..- & 248.0 & 880.38 & $\ldots$ & --- & $\ldots$ & $\ldots$ \\
\hline$\ldots$ & $\ldots$ & 258.0 & 879.08 & $-\ldots$ & $-\ldots$ & $\ldots$ & $-\ldots$ \\
\hline$\ldots$ & $\ldots-$ & 268.0 & 879.58 &..- & -- & $-\cdots$ & $-\ldots$ \\
\hline .... & .... & 278.0 & 884.48 & $\ldots$ & ...- & -... & -..- \\
\hline 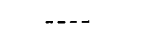 & $\ldots$ & 281.0 & 893.48 & $\ldots$ & --- & $\ldots$ & $-\cdots$ \\
\hline .... & $-\ldots$ & 308.0 & 899.80 & $-\ldots$ & --- & $-\ldots$ & $-\cdots$ \\
\hline \multicolumn{2}{|c|}{ River mile 336.93} & \multicolumn{2}{|c|}{ River mile 337.46} & \multicolumn{2}{|c|}{ River mile 337.77} & \multicolumn{2}{|c|}{ River mile 338.19} \\
\hline $\begin{array}{l}\text { Horizontal } \\
\text { distance } \\
\text { (ft) }\end{array}$ & $\begin{array}{c}\text { Altitude } \\
\quad(\mathrm{ft})\end{array}$ & $\begin{array}{l}\text { Horizontal } \\
\text { distance } \\
\text { (ft) }\end{array}$ & $\begin{array}{l}\text { Altitude } \\
\text { (ft) }\end{array}$ & $\begin{array}{l}\text { Horizontal } \\
\text { distance } \\
\text { (ft) }\end{array}$ & $\begin{array}{c}\text { Altitude } \\
\text { (ft) }\end{array}$ & $\begin{array}{l}\text { Horizontal } \\
\text { distance } \\
(\mathrm{ft})\end{array}$ & $\begin{array}{l}\text { Altitude } \\
\text { (ft) }\end{array}$ \\
\hline 2.0 & 905.0 & 15.0 & 903.0 & 1.0 & 906.3 & 0.1 & 902.0 \\
\hline 51.2 & 899.2 & 27.0 & 896.1 & 20.0 & 893.5 & 1.0 & 894.2 \\
\hline 68.0 & 888.9 & 29.0 & 892.0 & 50.0 & 891.2 & 10.0 & 893.4 \\
\hline 97.5 & 887.0 & 47.5 & 889.5 & 98.0 & 889.5 & 20.0 & 891.0 \\
\hline 130.0 & 888.0 & 61.0 & 888.0 & 149.0 & 889.5 & 35.0 & 889.5 \\
\hline 158.0 & 887.0 & 73.5 & 888.0 & 180.0 & 890.5 & 50.0 & 889.4 \\
\hline 188.0 & 888.0 & 92.0 & 888.4 & 196.0 & 893.3 & 100.0 & 889.6 \\
\hline 208.0 & 887.0 & 125.5 & 888.5 & 220.0 & 907.3 & 120.0 & 888.5 \\
\hline 248.0 & 888.0 & 154.5 & 888.9 & -... & $\ldots$ & 140.0 & 887.8 \\
\hline 280.0 & 898.5 & 175.0 & 888.7 & _._- & -.-- & 160.0 & 887.2 \\
\hline 304.0 & 903.4 & 185.5 & 887.9 & $-\ldots$ & $-\ldots$ & 176.0 & 887.9 \\
\hline - & ... & 209.5 & 887.8 & ... & .... & 190.0 & 896.0 \\
\hline$\ldots$ & $-\ldots$ & 216.0 & 890.1 & $-\ldots$ & --- & 195.0 & 903.7 \\
\hline$\ldots$ & $-\ldots$ & 219.0 & 896.1 & $\ldots$ & $\ldots$ & $\ldots$ & $\ldots$ \\
\hline - & $\ldots$ & 230.0 & 903.0 & -1 & $\ldots$ & (n... & $\ldots$ \\
\hline
\end{tabular}


TABLE 13.-Summary of cross-8ection data-Continued

\begin{tabular}{|c|c|c|c|c|c|c|c|}
\hline \multicolumn{2}{|c|}{ River mile 338.63} & \multicolumn{2}{|c|}{ River mile 338.98} & \multicolumn{2}{|c|}{ River mile $\mathbf{3 3 9 . 5 8}$} & \multicolumn{2}{|c|}{ River mile 339.86} \\
\hline $\begin{array}{l}\text { Horizontal } \\
\text { distance } \\
\text { (ft) }\end{array}$ & $\begin{array}{l}\text { Altitude } \\
\text { (ft) }\end{array}$ & $\begin{array}{l}\text { Horizontal } \\
\text { distance } \\
(\mathrm{ft})\end{array}$ & $\begin{array}{c}\text { Altitude } \\
\text { (ft) }\end{array}$ & $\begin{array}{l}\text { Horizontal } \\
\text { distance } \\
(\mathrm{ft})\end{array}$ & $\begin{array}{c}\text { Altitude } \\
(\mathrm{ft})\end{array}$ & $\begin{array}{l}\text { Horizontal } \\
\text { distance } \\
(\mathrm{ft})\end{array}$ & $\begin{array}{l}\text { Altitude } \\
\text { (ft) }\end{array}$ \\
\hline 3.0 & 905.0 & 15.5 & 910.5 & 25.0 & 908.0 & 8.0 & 918.00 \\
\hline 8.0 & 893.0 & 17.0 & 898.5 & 28.0 & 898.7 & 12.0 & 901.55 \\
\hline 12.0 & 888.8 & 24.0 & 895.1 & 30.0 & 896.1 & 15.0 & 891.57 \\
\hline 26.5 & 887.8 & 43.5 & 890.8 & 40.0 & 895.7 & 25.0 & 887.40 \\
\hline 30.0 & 885.4 & 130.5 & 892.6 & 47.0 & 894.5 & 35.0 & 885.40 \\
\hline 41.5 & 886.0 & 143.0 & 892.0 & 55.5 & 894.4 & 40.0 & 883.85 \\
\hline 113.0 & 886.0 & 164.0 & 892.0 & 62.0 & 890.9 & 45.0 & 882.71 \\
\hline 152.5 & 885.4 & 174.5 & 890.9 & 85.5 & 889.1 & 50.0 & 882.74 \\
\hline 173.0 & 883.5 & 185.0 & 891.5 & 120.0 & 891.0 & 55.0 & 882.67 \\
\hline 184.0 & 884.2 & 202.0 & 891.3 & 154.0 & 891.0 & 60.0 & 883.31 \\
\hline 190.5 & 888.6 & 206.5 & 891.5 & 184.0 & 893.1 & 65.0 & 883.85 \\
\hline 204.0 & 893.0 & 212.0 & 893.9 & 212.0 & 894.7 & 70.0 & 884.35 \\
\hline 225.0 & 904.0 & 218.0 & 898.5 & 213.0 & 898.7 & 80.0 & 885.98 \\
\hline$\ldots-$ & $\ldots$ & $\ldots$ & $\ldots$ & 222.0 & 905.8 & 90.0 & 887.51 \\
\hline$-\ldots$ & -..- & $\ldots$ & $\ldots$ & --- & $\ldots$ & 100.0 & 888.03 \\
\hline -..- & $\ldots$ & -- & $-\ldots$ & $\ldots$ & $\cdots$ & 110.0 & 888.86 \\
\hline$-\ldots$ & -..- & $-\cdots$ & --- & $\ldots$ & $\ldots$ & 120.0 & 889.29 \\
\hline 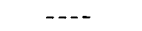 & $-\cdots$ & $-\cdots$ & --- & -... & $\ldots$ & 130.0 & 891.62 \\
\hline .... & $\ldots$ & $\ldots$ & .... & $\ldots$ & .... & 145.0 & 892.15 \\
\hline--- & $\ldots$ & $\ldots$ & $-\ldots$ & -... & $\ldots$ & 160.0 & 892.67 \\
\hline -..- & $\ldots$ & $\ldots$ & $\ldots$ & $-\ldots$ & $\ldots$ & 170.0 & 892.70 \\
\hline -... & $\ldots$ & --- & -..- & -..- & $\ldots$ & 180.0 & 894.90 \\
\hline -..- & $\cdots$ & $\cdots$ & $\ldots$ & --- & $\ldots$ & 190.0 & 897.70 \\
\hline$\cdots$ & $-\cdots$ & $\cdots-$ & $\ldots$ & $\ldots$ & $\ldots$ & 193.0 & 902.21 \\
\hline & & & & $\ldots$ & $-\ldots$ & 209.0 & 914.00 \\
\hline \multicolumn{2}{|c|}{ River mile 340.18} & \multicolumn{2}{|c|}{ River mile 340.86} & \multicolumn{2}{|c|}{ River mile 341.37} & \multicolumn{2}{|c|}{ River mile 342.00} \\
\hline $\begin{array}{l}\text { Horizontal } \\
\text { distance } \\
(\mathrm{ft})\end{array}$ & $\begin{array}{c}\text { Altitude } \\
\text { (ft) }\end{array}$ & $\begin{array}{l}\text { Horizontal } \\
\text { distance } \\
\text { ( } \mathrm{ft} \text { ) }\end{array}$ & $\begin{array}{l}\text { Altitude } \\
\text { (ft) }\end{array}$ & $\begin{array}{l}\text { Horizontal } \\
\text { distance } \\
\text { ( } \mathrm{ft} \text { ) }\end{array}$ & $\begin{array}{c}\text { Altitude } \\
(\mathrm{ft})\end{array}$ & $\begin{array}{l}\text { Horizontal } \\
\text { distance } \\
\text { (ft) }\end{array}$ & $\begin{array}{c}\text { Altitude } \\
\text { (ft) }\end{array}$ \\
\hline 15.0 & 912.6 & 15.0 & 909.5 & 15.0 & 910.5 & 2.5 & 912.0 \\
\hline 33.0 & 903.1 & 27.0 & 898.3 & 27.0 & 901.2 & 23.0 & 895.4 \\
\hline 36.0 & 895.7 & 35.0 & 894.9 & 33.0 & 896.8 & 50.0 & 894.4 \\
\hline 44.0 & 891.9 & 44.0 & 894.9 & 45.0 & 895.4 & 100.0 & 895.1 \\
\hline 51.5 & 891.7 & 47.5 & 891.7 & 70.0 & 896.4 & 150.0 & 895.5 \\
\hline 68.0 & 892.1 & 61.5 & 891.0 & 114.0 & 896.4 & 200.0 & 896.3 \\
\hline 112.5 & 892.1 & 82.5 & 892.0 & 142.0 & 895.4 & 222.0 & 909.4 \\
\hline 136.0 & 890.5 & 89.0 & 892.1 & 165.0 & 895.2 & -.... & $-\ldots$ \\
\hline 148.0 & 890.6 & 105.0 & 893.3 & 183.5 & 894.7 & $\ldots$ & $\ldots$ \\
\hline 160.0 & 891.2 & 143.0 & 893.3 & 195.0 & 893.5 & -.- & $\ldots$ \\
\hline 169.5 & 891.3 & 163.0 & 892.2 & 211.0 & 892.6 & -... & $\ldots$ \\
\hline i74.0 & 890.5 & 172.0 & 892.1 & 235.0 & 894.4 & $\ldots$ & $\ldots$ \\
\hline 191.0 & 890.3 & 184.5 & 891.2 & 246.0 & 896.7 & -... & -... \\
\hline 207.0 & 889.6 & 201.0 & 892.2 & 264.0 & 897.9 & $\ldots$ & $\ldots$ \\
\hline 220.5 & 890.3 & 208.0 & 894.5 & 270.0 & 901.2 & -..- & $\ldots$ \\
\hline 228.5 & 895.7 & 215.5 & 898.2 & 272.0 & 908.0 & -..- & $\ldots$ \\
\hline 231.0 & 907.0 & 219.0 & 910.2 & $\ldots$ & $\ldots$ & -... & .... \\
\hline
\end{tabular}


TABLE 13.-Summary of cross-8ection data-Continued

\begin{tabular}{|c|c|c|c|c|c|c|c|}
\hline \multicolumn{2}{|c|}{ River mile 342.54} & \multicolumn{2}{|c|}{ River_mile 343.21} & \multicolumn{2}{|c|}{ River mile $\mathbf{3 4 3 . 6 0}$} & \multicolumn{2}{|c|}{ River mile 344.16} \\
\hline $\begin{array}{l}\text { Horizontal } \\
\text { distance } \\
\text { (ft) }\end{array}$ & $\begin{array}{c}\text { Altitude } \\
(\mathrm{ft})\end{array}$ & $\begin{array}{l}\text { Horizontal } \\
\text { distance } \\
(\mathrm{ft})\end{array}$ & $\begin{array}{l}\text { Altitude } \\
\text { (ft) }\end{array}$ & $\begin{array}{l}\text { Horizontal } \\
\text { distance } \\
\text { (ft) }\end{array}$ & $\begin{array}{c}\text { Altitude } \\
\text { (ft) }\end{array}$ & $\begin{array}{l}\text { Horizontal } \\
\text { distance } \\
\text { (ft) }\end{array}$ & $\begin{array}{l}\text { Altitude } \\
\text { (ft) }\end{array}$ \\
\hline 94.0 & 914.9 & 1.0 & 913.0 & 150.0 & 922.0 & 15.0 & 920.6 \\
\hline 94.5 & 908.7 & 14.5 & 900.7 & 205.0 & 921.0 & 37.0 & 906.5 \\
\hline 100.5 & 904.5 & 18.0 & 899.0 & 230.0 & 907.5 & 41.0 & 902.3 \\
\hline 121.0 & 904.0 & 58.0 & 898.1 & 239.0 & 906.1 & 55.5 & 901.7 \\
\hline 121.5 & 900.9 & 79.0 & 898.3 & 248.0 & 909.9 & 70.5 & 896.9 \\
\hline 133.5 & 900.3 & 93.0 & 898.3 & 280.0 & 904.2 & 91.5 & 896.9 \\
\hline 142.5 & 900.9 & 110.0 & 898.3 & 340.0 & 901.3 & 103.5 & 896.4 \\
\hline 163.5 & 901.4 & 121.0 & 898.5 & 356.0 & 902.5 & 136.0 & 899.1 \\
\hline 172.5 & 901.9 & 137.0 & 898.4 & 400.0 & 901.0 & 157.5 & 899.7 \\
\hline 190.0 & 902.1 & 206.0 & 899.0 & 440.0 & 901.0 & 172.5 & 898.9 \\
\hline 208.0 & 902.7 & 211.0 & 900.7 & 460.0 & 898.8 & 180.5 & 900.0 \\
\hline 224.5 & 902.8 & 236.0 & 913.0 & 485.0 & 902.3 & 192.0 & 900.5 \\
\hline 235.5 & 902.1 & $\ldots$ & $\ldots$ & 520.0 & 914.0 & 207.0 & 900.5 \\
\hline 247.5 & 902.6 & $\ldots$ & $\ldots$ & 540.0 & 918.4 & 216.0 & 899.3 \\
\hline 264.5 & 901.7 & $\ldots$ & .... & $\ldots$ & $\ldots$ & 226.5 & 901.9 \\
\hline 280.5 & 904.1 & $\ldots$ & $\ldots$ & $\ldots$ & $\ldots$ & 240.5 & 902.0 \\
\hline 283.5 & 908.5 & $-\ldots$ & $\ldots$ & $-\ldots$ & $\ldots$ & 245.5 & 906.5 \\
\hline 285.0 & 913.0 & $\ldots$ &.-- & --- & $-\cdots$ & 246.0 & 918.6 \\
\hline \multicolumn{2}{|c|}{ River mile 344.69} & \multicolumn{2}{|c|}{ River mile $\mathbf{3 4 4 . 8 7}$} & \multicolumn{2}{|c|}{ River mile 345.02} & \multicolumn{2}{|c|}{ River mile 345.52} \\
\hline $\begin{array}{l}\text { Horizontal } \\
\text { distance } \\
\text { (ft) }\end{array}$ & $\begin{array}{c}\text { Altitude } \\
(\mathrm{ft})\end{array}$ & $\begin{array}{c}\text { Horizontal } \\
\text { distance } \\
\text { (ft) }\end{array}$ & $\begin{array}{l}\text { Altitude } \\
\text { (ft) }\end{array}$ & $\begin{array}{l}\text { Horizontal } \\
\text { distance } \\
\text { (ft) }\end{array}$ & $\begin{array}{l}\text { Altitude } \\
\text { (ft) }\end{array}$ & $\begin{array}{l}\text { Horizontal } \\
\text { distance } \\
(f t)\end{array}$ & $\begin{array}{c}\text { Altitude } \\
(\mathrm{ft})\end{array}$ \\
\hline 1.0 & 920.5 & 2.5 & 922.0 & 1.0 & 916.1 & 1.0 & 917.5 \\
\hline 47.0 & 896.9 & 20.0 & 910.0 & 11.0 & 913.0 & 20.0 & 907.6 \\
\hline 56.0 & 896.3 & 31.0 & 901.3 & 27.0 & 902.3 & 36.0 & 902.5 \\
\hline 78.0 & 898.2 & 50.0 & 897.2 & 72.0 & 895.0 & 69.0 & 891.0 \\
\hline 100.0 & 896.0 & 100.0 & 894.5 & 103.0 & 897.0 & 107.0 & 899.5 \\
\hline 122.0 & 897.0 & 150.0 & 895.4 & 141.0 & 899.3 & 142.0 & 901.0 \\
\hline 137.0 & 898.2 & 200.0 & 902.5 & 167.0 & 900.5 & 197.0 & 902.5 \\
\hline 177.0 & 898.4 & 214.0 & 913.5 & 207.0 & 902.3 & 206.0 & 906.1 \\
\hline 204.0 & 904.7 & 231.0 & 918.5 & 232.0 & 904.8 & 207.0 & 913.7 \\
\hline 209.0 & 910.6 & 272.0 & 923.4 & 267.0 & 906.2 & _. - & ... \\
\hline 215.0 & 915.6 & - & $\ldots$ & 268.0 & 918.2 & -... & -..- \\
\hline
\end{tabular}


TABLE 13.-Summary of cross-section data-Continued

\begin{tabular}{|c|c|c|c|c|c|c|c|}
\hline \multicolumn{2}{|c|}{ River mile 345.80} & \multicolumn{2}{|c|}{ River mile 346.06} & \multicolumn{2}{|c|}{ River mile $\mathbf{3 4 6 . 5 2}$} & \multicolumn{2}{|c|}{ River mile $\mathbf{3 4 7 . 0 7}$} \\
\hline $\begin{array}{l}\text { Horizontal } \\
\text { distance } \\
\text { (ft) }\end{array}$ & $\begin{array}{l}\text { Altitude } \\
\text { (ft) }\end{array}$ & $\begin{array}{l}\text { Horizontal } \\
\text { distance } \\
\text { ( } \mathrm{ft})\end{array}$ & $\begin{array}{l}\text { Altitude } \\
\text { (ft) }\end{array}$ & $\begin{array}{l}\text { Horizontal } \\
\text { distance } \\
\text { (ft) }\end{array}$ & $\begin{array}{l}\text { Altitude } \\
\text { (ft) }\end{array}$ & $\begin{array}{l}\text { Horizontal } \\
\text { distance } \\
\text { (ft) }\end{array}$ & $\begin{array}{l}\text { Altitude } \\
\text { (ft) }\end{array}$ \\
\hline 45.0 & 917.80 & 2.5 & 921.0 & 15.0 & 909.0 & 15.0 & 922.0 \\
\hline 90.0 & 912.98 & 49.9 & 900.1 & 16.5 & 902.7 & 24.0 & 904.1 \\
\hline 100.0 & 906.57 & 100.0 & 895.4 & 18.0 & 899.5 & 25.5 & 900.7 \\
\hline 110.0 & 905.20 & 150.0 & 894.6 & 45.5 & 898.1 & 32.0 & 900.0 \\
\hline 120.0 & 899.31 & 200.0 & 895.2 & 63.5 & 896.4 & 45.0 & 897.3 \\
\hline 125.0 & 898.82 & 240.0 & 899.2 & 68.0 & 896.4 & 53.0 & 896.4 \\
\hline 135.0 & 897.32 & 280.0 & 924.4 & 75.5 & 896.9 & 73.0 & 896.0 \\
\hline 145.0 & 897.53 & .... & .... & 88.0 & 896.9 & 83.5 & 894.3 \\
\hline 155.0 & 896.43 & $\ldots$ & -..- & 100.0 & 895.8 & 95.0 & 894.7 \\
\hline 165.0 & 897.94 & $\ldots$ & $\cdots$ & 125.0 & 895.6 & 105.0 & 894.3 \\
\hline 175.0 & 898.04 & .... & $\ldots$ & 175.5 & 896.0 & 123.5 & 895.6 \\
\hline 185.0 & 898.74 & $\ldots$ & -... & 182.0 & 896.7 & 148.0 & 896.6 \\
\hline 195.0 & 898.55 & -... & $\ldots$ & 189.0 & 896.1 & 176.5 & 899.6 \\
\hline 205.0 & 898.55 & $\ldots$ & -... & 200.5 & 896.0 & 194.5 & 900.2 \\
\hline 215.0 & 899.46 & $-\ldots$ & $-\cdots$ & 210.0 & 897.1 & 208.5 & 902.8 \\
\hline 225.0 & 898.06 & -... & -... & 211.5 & 902.7 & 218.0 & 902.9 \\
\hline 235.0 & 898.26 & -..- & $\ldots$ & 213.0 & 911.8 & 219.5 & 904.1 \\
\hline 245.0 & 898.46 & $\ldots$ & $-\cdots$ & $\ldots$ & $\ldots$ & 220.5 & 922.0 \\
\hline 255.0 & 898.57 & $\ldots$ & $\ldots$ & $\ldots$ & $\ldots$ & $\ldots$ & $\ldots$ \\
\hline 265.0 & 899.47 & $-\ldots$ & $\ldots$. & $\ldots$ & $\ldots$ & $\ldots$ & $\ldots$ \\
\hline 275.0 & 899.07 & $-\ldots$ & $\ldots$ & $\ldots$ & $\ldots$ & $\ldots$ & $\ldots$ \\
\hline 285.0 & 899.08 & $\ldots$ & $-\cdots$ & $-\ldots$ & $\cdots$ & $\ldots$ & $-\ldots$ \\
\hline 295.0 & 899.48 & $-\ldots$ & $\ldots$ & -..- & $\ldots$ & $-\ldots$ & $-\ldots$ \\
\hline 305.0 & 901.38 & $\ldots$ &.-- & $-\cdots$ & $\cdots$ & $\cdots$ & $-\ldots$ \\
\hline 315.0 & 904.08 & --- & --- & $\cdots$ & $\cdots$ & --- & $\cdots$ \\
\hline$\therefore 25.0$ & 905.28 & -... & -..- & -..- & ...- & --- & $\ldots$ \\
\hline 335.0 & 907.39 & -..- & -..- & $\ldots$ & $\ldots$ & -... & $\ldots$ \\
\hline 345.0 & 912.09 & $\ldots$ & $\cdots$ & $\ldots$ & 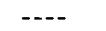 & $\ldots$ & $\ldots$ \\
\hline 355.0 & 913.09 & $\ldots$ & 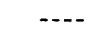 & --- &.-- & $-\cdots$ & -... \\
\hline 425.0 & 919.60 & -..- & -... & & & & \\
\hline
\end{tabular}

\begin{tabular}{|c|c|c|c|c|c|c|c|}
\hline \multicolumn{4}{|c|}{ River mile 347.42} & \multicolumn{2}{|c|}{ River mile 347.97} & \multicolumn{2}{|c|}{ River mile $\mathbf{3 4 8 . 1 0}$} \\
\hline \multicolumn{2}{|c|}{ Channel 1} & \multicolumn{2}{|c|}{ Channel 2} & \multirow[b]{2}{*}{$\begin{array}{c}\text { Horizontal } \\
\text { distance } \\
\text { (ft) }\end{array}$} & \multirow[b]{2}{*}{$\begin{array}{l}\text { Altitude } \\
\text { (ft) }\end{array}$} & \multirow[b]{2}{*}{$\begin{array}{c}\text { HorizontaI } \\
\text { distance } \\
\text { (ft) }\end{array}$} & \multirow[b]{2}{*}{$\begin{array}{c}\text { Altitude } \\
\text { (ft) }\end{array}$} \\
\hline $\begin{array}{l}\text { Horizontal } \\
\text { distance } \\
\text { (ft) }\end{array}$ & $\begin{array}{l}\text { Altitude } \\
\text { (ft) }\end{array}$ & $\begin{array}{l}\text { Horizontal } \\
\text { distance } \\
\text { (ft) }\end{array}$ & $\begin{array}{l}\text { Altitude } \\
(\mathrm{ft})\end{array}$ & & & & \\
\hline 15.0 & 916.0 & 345.0 & 920.0 & 39.0 & 925.0 & 2.0 & 925.1 \\
\hline 16.0 & 907.0 & 360.0 & 906.0 & 51.0 & 911.5 & 32.0 & 907.7 \\
\hline 16.5 & 906.2 & 361.5 & 902.2 & 92.0 & 909.3 & 50.0 & 906.5 \\
\hline 18.0 & 902.6 & 363.3 & 902.2 & 144.0 & 909.8 & 100.0 & 909.6 \\
\hline 29.1 & 901.2 & 364.8 & 900.6 & 201.0 & 910.2 & 200.0 & 905.5 \\
\hline 45.0 & 898.2 & 387.0 & 898.4 & 233.0 & 910.6 & 250.0 & 906.5 \\
\hline 56.2 & 898.2 & 394.0 & 896.3 & 254.0 & 910.2 & 300.0 & 906.5 \\
\hline 70.8 & 898.6 & 401.5 & 896.3 & 260.0 & 909.2 & 332.0 & 926.6 \\
\hline 108.0 & 898.6 & 404.5 & 897.5 & 306.0 & 909.3 & --- & $\ldots$ \\
\hline 116.3 & 898.3 & 412.8 & 897.5 & 322.0 & 911.5 & --- & -..- \\
\hline 137.6 & 899.0 & 417.8 & 898.1 & 326.0 & 925.0 & $\ldots$ & - - \\
\hline 170.6 & 899.2 & 430.8 & 898.3 & -..- & $\ldots$ & $\ldots$ & $\ldots$ \\
\hline 185.0 & 901.4 & 434.8 & 900.8 & $\ldots$ & $-\ldots$ & $\ldots$ & $\ldots$ \\
\hline 186.0 & 902.0 & 443.5 & 901.8 & -... & - & - . - & $\ldots$ \\
\hline 191.0 & 902.4 & 447.5 & 903.2 & $\ldots$ & --- & -- & --- \\
\hline 192.0 & 906.2 & 457.5 & 918.0 & - - - - & - & $\ldots$ & - . - \\
\hline 193.0 & 918.0 & 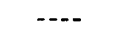 & $\cdots$ & $\cdots$ & $\ldots$ & -- & $-\cdots$ \\
\hline
\end{tabular}

